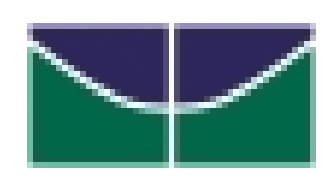

Universidade de Brasília Centro de Excelência em Turismo

\title{
PATRIMÔNIO IMATERIAL E A SUA INTERFACE COM O DESENVOLVIMENTO DO TURISMO NO BRASIL
}

Aluna: Luciana de Almeida

Orientadora: Profa. Dra ${ }^{a}$ Mariza Veloso

Monografia apresentada ao Centro de Excelência em Turismo da Universidade de Brasília como requisito parcial para a obtenção do certificado de Especialista em Turismo: Cultura e Lazer.

Brasília - DF, Junho 2005 


\author{
Universidade de Brasília \\ Centro de Excelência em Turismo
}

Curso de Especialização em Turismo: Cultura e Lazer

PATRIMÔNIO IMATERIAL E A SUA INTERFACE COM O DESENVOLVIMENTO DO TURISMO NO BRASIL

Aluna: Luciana de Almeida

Banca Examinadora:

Orientadora: Prof ${ }^{a}$. Dra. Mariza Veloso

Membro: Profa ${ }^{a}$ Dr ${ }^{a}$. Dulce Suassuna

Brasília - DF, Junho 2005 


\section{Resumo}

Este estudo propõe uma reflexão sobre a relação dialética entre cultura e turismo sob o enfoque da política de preservação de patrimônio cultural, em sua nova dimensão, o chamado patrimônio imaterial e a sua interface com o desenvolvimento do turismo no Brasil, no âmbito das políticas públicas do Governo Federal. Para isso, apresenta-se o contexto histórico de formulação das políticas públicas de Patrimônio Imaterial e Turismo, compreendendo o período a partir do Decreto que instituiu "o Registro de Bens Culturais de Natureza Imaterial que constituem o patrimônio cultural brasileiro e cria 0 Programa Nacional do Patrimônio Imaterial" em 2000, bem como, o período de criação do Ministério do Turismo (MTur) em 2003.

O caminho escolhido para essa reflexão foi a análise crítica dos dois instrumentos centrais dessas políticas: o Plano Nacional de Turismo e o Programa Nacional do Patrimônio Imaterial. São dois os principais focos de trabalho: 1) Identificar o teor da política de preservação do patrimônio imaterial e a sua possível interface com o desenvolvimento das políticas nacionais de turismo. 2) Promover a discussão sobre a relação entre as duas políticas, considerando a pergunta norteadora, Patrimônio Imaterial e Turismo: questões incompatíveis?

Tal investigação procurou identificar nas políticas o que vem sendo apresentado nos discursos e imagens do turismo, a cultura brasileira como recurso turístico, entendendo que o patrimônio imaterial já vem emergindo no cenário do turismo, mas muito mais nas fases de agenda e atos discursivos do que de construção de práticas e políticas efetivas e integradas. 


\begin{abstract}
This study reflects upon the relation between culture and tourism under the political focus of cultural patrimony preservation, in its new dimension, known as the immaterial patrimony and its interaction with the development of tourism in Brazil, within the scope of the politics of the Federal Government. With this in mind, the historical context of formulation of Immaterial Patrimony and Tourism politics is presented, spanning the period from the decree that instituted the "Register of Cultural Goods of Immaterial Nature that constitute the Brazilian cultural patrimony and creates the National Program of Immaterial Patrimony " in 2000, as well as the period of creation of the Ministry of the Tourism (MTur) in 2003.

The path chosen for this reflection was the critical evaluation of the two central instruments of these politics: the National Plan of Tourism and the National Program of Immaterial Patrimony. The main focus of this study is: 1. To identify the content of the politics of preservation of the Immaterial Patrimony and its interaction with the development of the national politics of tourism. 2. To promote the discussion of the relation between the two political approaches, considering the question, Immaterial Patrimony and Tourism: incompatible approaches?

Such inquiry tries to identify in the politics what is being presented in the speeches and images of the tourism, the Brazilian culture as tourism resource, understanding that the Immaterial Patrimony is emerging in the tourism scene, but much more in the official speeches instead of building effective and integrated practices and politics.
\end{abstract}


O presente estudo foi sendo construindo pelas oportunidades de lugares e pessoas com quem convivi ao longo de toda minha vida.

Primeiramente, agradeço a Deus por me conduzir na viagem da vida. Agradeço aos professores e amigos da pós, à minha orientadora Profa ${ }^{\text {.Dra }}$. Mariza Veloso, que soube, com paciência me iluminar nos caminhos teóricos, pelo apoio nas horas difíceis e por me podar e dar asas nas horas certas, aos pesquisadores do Iphan que desbravaram a inédita Política Nacional do Patrimônio Imaterial, à equipe do Ministério do Turismo, onde trabalhei, construtores dessa nova Política Pública de Turismo à qual eu torço, a minha amiga Ana Zerbini pelas nossas conversas filosóficas e é claro, agradeço a "idéia", que me perseguiu insistentemente e me escolheu para se materializar.

Agradeço a minha família, especialmente a minha mãe Cleusa que me envolveu nos saberes, fazeres e nas celebrações e práticas culturais cotidianas, aos meus 3 irmãos pela força material e imaterial, e a minha amigairmã, Luciana Namias, que conhecendo minha alma me incentivou a fazer esta especialização; ao meu marido Pedro, que pacientemente me incentivou a seguir enfrente mesmo com o pé quebrado e na hora que quase desisti; a minha filha Lívia Emanuelle, que soube compreender a minha ausência e ao meu filho Pedro lan, menorzinho de quase três anos, que não compreendendo tanto, ligava o som bem alto na música a "I Feel Good", de James Brown, me retirando daquela solidão reflexiva a que me debrucei durante os meses de realização desta pesquisa e assim me fazia sorrir...

Os meus sinceros agradecimentos às pessoas e instituições que colaboram com essa pesquisa, citados ou não ao longo destas páginas e principalmente àqueles que dedicaram algum tempo para responderem as entrevistas e indagações ou em conversas informais. 


\section{Sumário}

Introdução. 09

\section{Capitulo 1}

1. Patrimônio imaterial e turismo, evidência na agenda nacional e internacional...... 16

1.10 decreto que institui o registro do patrimônio imaterial $-2000 \ldots \ldots \ldots \ldots \ldots \ldots \ldots \ldots . . . .18$

1.2 A criação do Ministério do Turismo (MTur) - 2003...........................................22

\section{Capitulo 2}

2. (Pós) modernidade (s): o presente senso de complexidade e fragmentação......... 28

2.1. Turismo uma invenção legitimada nos tempos modernos.................................32

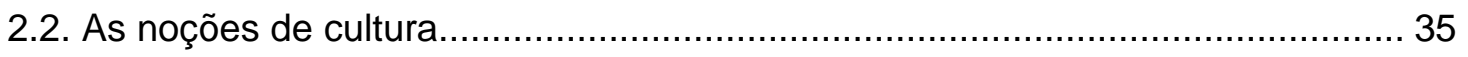

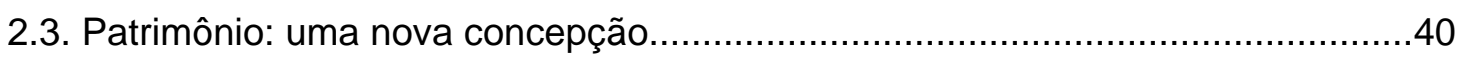

\section{Capitulo 3}

3. Análise do Plano Nacional de Turismo e do Programa Nacional do Patrimônio

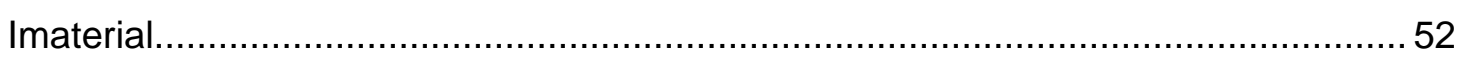

3.1. O Plano Nacional do Turismo (PNT: 2003-2007).......................................... 52

3.2. O papel de articulação do MTur e a gestão descentralizada...............................55

3.3. O Programa Nacional do Patrimônio Imaterial - PNPI......................................59

3.4. Patrimônio imaterial: protagonização nos discursos e imagens do turismo......... 72

3.5. Interfaces na atuação entre os "campos" de poder......................................... 74

3.6. A cultura como recurso político, econômico e turístico.......................................77

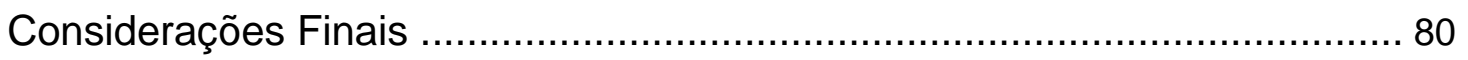

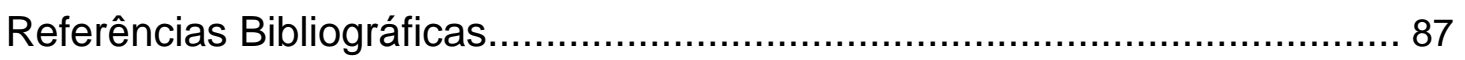

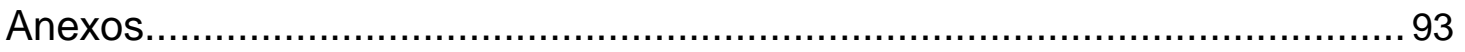


Anexo A

Decreto $n^{\circ} 3.551$ de 4 de agosto de 2000, que Institui o Registro de Bens Culturais de Natureza Imaterial que constituem patrimônio cultural brasileiro, cria o Programa Nacional do Patrimônio Imaterial e dá outras providências.

Anexo B

Plano Nacional do Turismo - Diretrizes, Metas e Programas (PNT: 2003-2007), Ministério do Turismo, 2003.

Anexo C

Composição do Conselho Nacional de Turismo - CNT atualizada em junho/2005, cedido pela Coordenação do CNT (MTur/SNPT/DPAT/MartaFeitosa).

Anexo D

Programa Nacional do Patrimônio Imaterial - IPHAN, Ministério da Cultura, 2000.

Anexo E

Quadro de Representação das Entidades do Conselho Nacional de Turismo nas Câmaras Temáticas de Junho/2005, cedido pela Coordenação do CNT (MTur/SNPT/DPAT/MartaFeitosa).

Anexo F

Levantamento de Presenças das Entidades nas Reuniões do Conselho Nacional de Turismo, atualizado em 27/06/05, cedido pela Coordenação do CNT (MTur/SNPT/DPAT/MartaFeitosa)

Anexo G

Composição do Conselho Estadual de Turismo do Espírito Santo CONTURES, cedido pela Coordenação dos Fóruns/Conselhos Estaduais de Turismo (MTur/SNPT/DPAT).

Anexo $\mathrm{H}$

Fotos da Associação das Paneleiras de Goiabeiras, cedidas por Tatiana Petra e Bruna Neiva, especialistas do Ministério do Turismo, realizadas em abril/2005 durante visita técnica e de inventariado à associação. (MTur/SNPDT/CGPAT)

Anexo I

Planta do Projeto "Vitrine Brasil" e os Produtos Associados ao Turismo apresentados pelos 9 Sítios Urbanos Patrimônios Mundiais no Brasil (Planta cedida por Ana Zerbini, arquiteta do projeto). 
"Tudo na vida está dividido em duas partes, das quais uma é visível, e a outra invisível. Aquela que é visível, nada mais é do que o reflexo da invisível." Zohan 
A concepção temática deste estudo adveio das reflexões latentes durante o curso de especialização da UnB - Turismo: Cultura e Lazer sobre o turismo em relação dialética com a cultura, fazendo parte das discussões e preocupações da agenda mundial sobre os rumos do desenvolvimento do turismo.

Dentro dessa vastidão temática: Turismo e Cultura, delimitou-se como recorte: o Patrimônio Imaterial e sua interface com o desenvolvimento do turismo no Brasil, no período compreendido entre a publicação do Decreto $\mathrm{n}^{\circ}$ 3.551, de 4 de agosto de 2000, que instituiu o Registro de Bens Culturais de Natureza Imaterial que constituem patrimônio cultural brasileiro e cria o Programa Nacional do Patrimônio Imaterial (PNPI) e a criação do Ministério do Turismo (MTur), o que ocorreu em 01 de janeiro de 2003, pela Medida Provisória no. 103. A importância da criação do MTur se dá pois o turismo recebe um ministério específico pela primeira vez na história do país, deixando de ser apêndice de outros ministérios. À escolta dessa primeira medida administrativa, soma-se em seguida o lançamento do Plano Nacional de Turismo/PNT: 2003-2007, primeiro documento do MTur consolidando as principais diretrizes, metas e programas, voltado à organização política e ao desenvolvimento do setor no Brasil. Ambas as políticas - PNPI e PNT, são novatas no cenário brasileiro, apesar de datarem de aspirações de visionários antigos, como Mário de Andrade (ver histórico sobre o Patrimônio Imaterial).

Já é dito popular que "existe o momento certo para todas as coisas", o chamado pelos gregos de "tempo kairos". ${ }^{1}$ Este pareceu um momento oportuno e imperativo à reflexão sobre patrimônio imaterial na interface com a expansão do turismo, já que o turismo bate às portas brasileiras, gerando um clima de otimismo, suscitado pela criação do Ministério do Turismo. Na contrapartida, o turismo "predatório" tem sido apontado como um dos principais "problemas que interferem na continuidade e na manutenção de expressões da cultura tradicional", segundo relatório da Comissão e do Grupo de Trabalho Patrimônio

\footnotetext{
${ }^{1}$ A palavra kairos, em grego, significa o momento certo. kairos é uma antiga noção grega que se refere a um aspecto qualitativo do tempo, alusão a uma experiência temporal na qual percebemos o momento oportuno em relação à determinada ação.
} 
Imaterial (GTPI), ligado ao Instituto do Patrimônio Histórico e Artístico Nacional - IPHAN. De alguma forma, o desenvolvimento do turismo produz impactos que tem conseqüências culturais, sociais, econômicas e ambientais, que podem ser positivas ou negativas. Nesse contexto, percebe-se uma discussão mais amadurecida que se pauta prioritariamente nos aspectos ambientais e econômicos enquanto o cultural e o social ainda não apresentam instrumentos reguladores definidos.

O impulso para este estudo considerou essa carência de ênfase aos aspectos culturais locais na relação com o turismo à guisa das preocupações acerca dos impasses ambientais, que parecem mais avançadas e encaminhadas, apesar do turismo de massa, exploratório, oportunista e não planejado ser inevitavelmente um fator de grandes desequilíbrios e destruição para ambos aspectos. Inclui-se aqui o aspecto social, que necessita de mais atenção na expansão do setor, já que às vezes, esse crescimento acaba reforçando os desequilíbrios sociais, a miséria, a prostituição e a criminalidade, mas isso seria motivo de um outro estudo.

Dessa forma, o desenvolvimento do turismo demanda uma perspectiva transversal, especialmente de políticas efetivas que promovam a cidadania e benefícios sociais e de proteção ao patrimônio cultural e natural. Essa discussão, por excelência, é interdisciplinar, interagindo cultura, turismo, economia, história, geografia, arquitetura, comunicação (informação), sociologia, antropologia, administração e a inclusão da comunidade local que é parte integrante do "lugar" onde se insere todo o processo de implementação turística. Senão corre-se o risco de mais uma vez, reproduzir a história dos 500 anos do Brasil, como se não existisse nem história, nem cultura, nem habitantes antes disso. Como fazer para não transformar o turismo brasileiro numa barbárie, em espetáculo para estrangeiros, em um não-lugar, nos termos de Marc Augé (1994). Não é pretensão desta monografia trazer tais respostas, no entanto, considera-se importante a interrogação como orientadora da reflexão proposta.

A participação da comunidade é essencial no processo turístico, como parte integrante do bem cultural e do local, pode transformar-se em seu natural defensor. "Turismo é movimento de pessoas, é um fenômeno que envolve, antes de mais nada, gente..." (Margarida Barreto, 2000). É de gente que 
estamos tratando, da nossa gente brasileira, diversificada e híbrida em sua própria origem, nos termos de Canclini (1997). Propõe-se uma ótica contrária a que tem sido verificada na prática do turismo, a ótica do lugar, portanto das pessoas que compõe o lugar. Assim, ao pensar em vocação turística deve-se pressupor a vocação do lugar, das pessoas que o compõe e de seus saberes locais.

A prática do turismo exige muitos processos, processos anteriores ao da prática do turismo efetivamente, o de captar demandas, de sensibilidade, de identificação, de interação, de mediação e antes de tudo, de bom senso. A idéia de que o melhor para o turista é o melhor para as pessoas do lugar e para o próprio lugar deveria ser norteadora e não uma exceção. Dessa dinâmica dependem a manutenção do destino turístico e o equilíbrio entre as partes envolvidas. Quando essa discussão é levada para os aspectos do patrimônio imaterial, ensejam "uma série de recomendações, em grande parte análogas àquelas dos bens materiais, voltadas para a identificação, salvaguarda, conservação e proteção jurídica", sublinha Márcia Sant'Anna no relatório final das atividades do GTPI/IPHAN (2000).

O objeto de investigação desta pesquisa concentra-se nos dois principais documentos das políticas públicas referentes: o Plano Nacional de Turismo (MTur) e o Programa Nacional do Patrimônio Imaterial (IPHAN/MinC). Analisa-se como as políticas de turismo têm sido implementadas e se há interface com o Patrimônio Imaterial. Tal investigação procura identificar na prática o que vem sendo apresentado nos discursos oficiais do governo federal e em palestras públicas, ilustrado na fala do presidente do Instituto Brasileiro de Turismo - EMBRATUR, Eduardo Sanovicz, no ciclo de palestra "Turismo em Movimento" - CET/UnB, em outubro de 2004, ressaltando que o que é "atrativo e nos diferencia é a qualidade e a diversidade cultural brasileira: nosso povo, nossa culinária, nossa música e nosso artesanato" nem tanto nossas praias e beleza natural, que concorrem com a sedução de outros lugares no mundo. Em uma matéria na Revista Eventos, Sanovicz ressaltou o compromisso de trabalhar pautado na diferença e na diversidade, para agregar valor: "Vamos construir em cima da pluralidade de pessoas, etnias, credos e diferentes ideologias políticas", disse. 
A mesma exaltação ao povo brasileiro tem sido reproduzida em discursos de outros atores que promovem as políticas públicas de turismo, pelo menos no plano do discurso, percebe-se mesmo uma valorização ao povo brasileiro. O Serviço Brasileiro de Apoio às Micro e Pequenas Empresas Sebrae tem promovido o projeto "Cara Brasileira" voltado para o desenvolvimento do turismo no Brasil, seguido do Governo Federal que lançou uma campanha publicitária nacional, com o tema: "O melhor do Brasil é o brasileiro", inspirado na frase do antropólogo e folclorista, Câmara Cascudo, com o objetivo de elevar a auto-estima do povo brasileiro. Não se pretende fazer aqui uma apologia ao nacionalismo, ao "passado", como forma de amarras as novidades e as mudanças, mas sim "ao passado como uma força, e não, como um fardo... é o futuro que nos impele ao passado" (Hannah Arendt, 2000), no sentido de continuidade das coisas. Os "saberes" e os "fazeres" carregam valor, aprimoramento, elaboração, técnica e conhecimento, nessa perspectiva, passado e futuro se completam, não há ruptura entre tradição e inovação.

A própria definição de desenvolvimento é ampliada pela Unesco, nos anos 70, remetendo à noção a abordagem de desenvolvimento cultural. Desde que a "noção de desenvolvimento cultural passou a ter significado para a Unesco, o projeto desenvolvimentista não deve apenas relacionar-se harmoniosamente com a cultura, mas deve, antes, encontrar nela as suas próprias raízes", afirma Medeiros (2004). Trata-se de como a tradição pode iluminar o futuro do turismo e mesmo valorizar o presente, perdendo o mito da coisa velha e do atraso.

Aborda-se também a complexidade que o conceito "Patrimônio Imaterial" remete, centrando o estudo nos últimos cinco anos, desde o decreto. Faz-se uma análise dos quatro livros que compõe o Registro de Bens Culturais de Natureza Imaterial que constituem patrimônio cultural brasileiro: Livro de Registro dos Saberes, Livro de Registro das Celebrações, Livro de Registro das Formas de Expressão, Livro de Registro dos Lugares. E é claro, deslocase essa discussão para esfera do desenvolvimento do turismo no Brasil, sobre interação de políticas com o objetivo de preservação do patrimônio imaterial nas intervenções turísticas. 
A relevância desse estudo se justifica, na importância de documentar e analisar as políticas de preservação cultural no que tange ao aspecto do patrimônio imaterial, contribuindo com a reflexão sobre política de patrimônio imaterial e a relação com o turismo. Políticas essas que podem agregar valores ao patrimônio imaterial potencializando-o como "recurso" turístico, que de forma planejada pode contribuir com a salvaguarda, revitalização e promoção do patrimônio imaterial. No cenário da globalização e da pós-modernidade, valores históricos e culturais, por vezes, ficam expostos a processos de atrito e de disputa de espaço, nesse aspecto, instaura-se certa fragilidade dessas manifestações transmitidas por um sistema baseado na tradição e oralidade, distantes dos aparatos que legitimam a vida moderna, são empurrados ao esquecimento ou a espetacularização, tornando imprescindíveis políticas que regulem sua proteção e relação com o mundo globalizado. O antídoto é forjado do "próprio veneno", é no entendimento às relações globalizadas que o local ganha recrudescimento, onde grupos antes sem expressão começam a operar relações de poder, e mesmo as relações mediáticas podem ser usadas a favor de grupos periféricos ou subalternos. De acordo com Featherstone (1997):

"O pós-modernismo também tem sido associado à avaliação positiva das culturas locais e populares, das tradições menores e da alteridade, excluídas devido à pretensão universalizante do moderno. Isso sugere uma sensibilidade cada vez maior aos níveis mais complexos da unidade, ao sincretismo, a heterogeneidade e aos aspectos vistos, porém não notados da vida" (1997).

O importante parece então entender o momento atual e como funciona o mecanismo da globalização e favorecer-se dele. "Decifra-me senão te devoro".

O objetivo principal desta pesquisa foi identificar e analisar o teor de políticas desenvolvidas com o propósito de preservação do patrimônio imaterial, verificando se essas políticas estão sendo aplicadas e integradas ao desenvolvimento das políticas nacionais de turismo, bem como observar se essas políticas vêm construindo um espaço de preservação do patrimônio cultural. Como objetivo secundário a pesquisa pretendeu promover a discussão sobre a interface entre as duas políticas, e por conseqüência, entre os dois órgãos federais: Ministério da Cultura e Ministério do Turismo. 
Diante dos objetivos propostos apresentou-se o seguinte problema: Como se dá a relação entre Patrimônio Imaterial e o desenvolvimento do turismo no âmbito das políticas públicas do Governo Federal?

Presume-se, primeiramente, que o patrimônio imaterial já vem emergindo no cenário do turismo, mas muito mais nas fases de agenda, discussão e preocupação do que de construção de práticas e políticas efetivas e integradas. Uma segunda hipótese foi a de que a política de patrimônio imaterial pode encontrar no turismo um aliado, tanto para a proteção do bem registrado como divulgação e promoção, previstos no art. 6 do Decreto n 3.551 de 4 de Agosto de 2000. Possivelmente, ações isoladas, mais de silêncio e falta de diálogo do que de interface, considerando-se um certo conflito de linhas de pensamento entre os dois ministérios.

A metodologia utilizada concentrou-se na forma bibliográfica, revisando a literatura pertinente e na análise documental sobre a interface entre as duas políticas. Na primeira etapa, portanto, realizou-se o levantamento bibliográfico, percebendo que a literatura com este enfoque ainda é escasso no Brasil e no plano internacional, detectando aí, a necessidade de promover essa discussão por meio de conversas informais e entrevistas com os principais representantes destas políticas. Na segunda etapa, promoveu-se o levantamento documental com visitas ao Ministério do Turismo e Ministério da Cultura, realizando o trabalho de pesquisa, coleta de dados e de documentos e conversas informais com técnicos, além da realização de 5 entrevistas, 4 delas de forma presencial e 1 por meio eletrônico, com os seguintes personagens: 1) Márcia Sant' Anna, Diretora do Departamento de Patrimônio Imaterial do IPHAN, 2) Ana Cláudia Lima e Alves, Gerente de Registro do Departamento de Patrimônio Imaterial do IPHAN, 3) Marta Feitosa Rodrigues, Coordenadora do Conselho Nacional do Turismo/MTur, 4) Ana Suely Zerbini, Consultora da Unesco junto à Coordenação-Geral de Produção Associada ao Turismo/MTur e 5) Antônio Augusto Arantes, Presidente do Iphan (por e-mail). Outras entrevistas no Ministério do Turismo ficaram prejudicadas devido ao curto espaço de um mês para sua realização, período em que pessoas chave estavam fora do Brasil ou envolvidas em ações nacionais de grande repercussão, como foi o caso do "I Salão do Turismo", em São Paulo, um dos principais programas do Ministério do Turismo. 
Optou-se neste trabalho pela seguinte estrutura: no capítulo 1 aborda-se o contexto histórico de formulação das políticas públicas de Patrimônio Cultural Imaterial e de Turismo no Brasil, enfatizando o período do Decreto que instituiu "o Registro de Bens Culturais de Natureza Imaterial que constituem o patrimônio cultural brasileiro e cria o Programa Nacional do Patrimônio Imaterial" em 2000 e o período de criação do Ministério do Turismo (MTur) em 2003. O capítulo 2 faz uma revisão da literatura com o objetivo de apresentar as principais variáveis investigadas no estudo sobre patrimônio imaterial e turismo e o modelo teórico adotado. São apresentados conceitos e estudos realizados por autores como Margarida Barreto, Márcia Sant'Anna, Antônio Augusto Arantes, Mike Featherstone, Roque de Barros Laraia, Mariza Veloso, John Urry, Cecília Londres, Marc Augé, entre outros. Nesta etapa mostra-se um pouco da crise conceitual acerca da expressão Patrimônio Imaterial e conceitos como turismo, patrimônio, patrimônio imaterial, cultura, cultura popular, referência cultural, pós-modernidade, Global x Local.

No capítulo 3 realiza-se uma análise crítica dos dois instrumentos centrais dessas políticas: o Plano Nacional de Turismo e o Programa Nacional do Patrimônio Imaterial, identificando o teor da política de preservação do patrimônio imaterial e a sua possível interface com o desenvolvimento das políticas nacionais de turismo. Promover a discussão sobre a relação entre as duas políticas, considerando a pergunta norteadora, Patrimônio Imaterial e Turismo: questões incompatíveis? Tal investigação procurou identificar nas políticas o que vem sendo apresentado nos discursos e imagens do turismo, a cultura brasileira como recurso turístico. O capítulo apóia-se no conceito de "campo de poder", de Pierre Bourdier (2004) e no conceito de cultura como recurso, amparado principalmente nas idéias de Yúdice (2004), em seus estudos apresentados no livro: A Conveniência da Cultura, usos da cultura na era global, só recentemente lançado no Brasil.

Nas considerações finais, são discutidas as conclusões, implicações deste estudo e recomendações a futuras investigações para ações práticas e possíveis caminhos a serem adotados com relação à responsabilidade $\mathrm{e}$ qualidade do desenvolvimento do turismo, no sentido de promover um turismo sustentável. 


\section{Patrimônio imaterial e turismo, evidência na agenda nacional e internacional}

Este capítulo visa apresentar o contexto e cenário histórico de formulação das políticas públicas de Patrimônio Cultural Imaterial e de Turismo no Brasil, tal como, configurou-se e evidenciou-se na agenda do atual governo federal.

Nesse sentido, o presente capítulo está circunscrito ao Decreto no. 3.551 de 4 de agosto de 2000, que institui o Registro de Bens Culturais de Natureza Imaterial e cria o Programa Nacional do Patrimônio Imaterial e a Medida Provisória $n^{\circ}$. 103, de 01 de janeiro de 2003, que cria o Ministério do Turismo. Amplia-se brevemente essa discussão enumerando os principais episódios históricos nacionais e internacionais que antecederam ou resultaram nos respectivos decretos.

Apesar de ambas as políticas somente tomarem forma documental e jurídica mais efetivamente depois dos anos 2000, suas concepções encontram espaço fértil principalmente por volta dos anos 70. Entretanto, seria uma insensatez e imprudência, não remeter essa discussão a meados dos anos 30 , quando o visionário Mário de Andrade concebe o embrião prematuro que se consolidaria sessenta e quatro anos depois no então decreto 3.551. "É Mário de Andrade quem semeia, entre as linhas e entrelinhas do Anteprojeto para o SPHAN de 1936, a consciência da diversidade cultural brasileira bem como o reconhecimento de que esta se exprime através de formas materiais quanto imateriais, tangíveis e intangíveis", contextualiza Medeiros (2004:43).

O nome Mário de Andrade está imbricado aos estudos sobre 0 patrimônio brasileiro, mas é interessante notar que o poeta foi tão inovador quanto avançado ao produzir o texto etnográfico - O turista aprendiz (1983), onde capta em suas viagens as "coisas aparentemente simples, mas que juntas constituem o todo de nossa cultura", decifra Laraia (2004;13). Duplamente visionário, o poeta já oferecia uma perspectiva transversal e ampla 
da interconexão entre turismo e cultura brasileira, no entanto, sua importância parece um pouco abnegada dos estudos do turismo no Brasil.

A incompreensão e pouca inteligibilidade dos meios intelectuais e políticos do final dos anos 30 às idéias andradeanas ressoam nos estudos de Falcão (2001), Laraia (2004), Garcia (2004), Medeiros (2004) entre outros pesquisadores. "A preservação da lenda ou da dança indígena não tinha a mesma legitimidade de um altar barroco resplandecendo a ouro. Era quase uma extravagância intelectual. Ter razão antes do tempo, diz o ditado, é errado" (Falcão, 2001:170).

Maria Laura Cavalcanti (2004) considera que Mário de Andrade erguese como um dos expoentes da área de estudos do folclore não apenas pelo interesse intelectual aos fatos estudados, mas também, por uma peculiar atitude existencial.

"No solo híbrido de suas pesquisas, insinuam-se também vozes próprias e distintas da sua - vozes "do povo" - captadas pelo ângulo mais universalista e humanista de sua aproximação (...) Assim, não é apenas por buscar e produzir conhecimento sobre o povo, mas também por comover-se com esse tipo de contato humano que Mário de Andrade pode ser considerado um folclorista. O folclore é, na arquitetura de sua obra, um canal privilegiado de religação com um mundo que aspira à totalidade". (Cavalcanti, 2004:)

Talvez, toda a sensibilidade, o encantamento, o olhar do poeta estavam à frente de seu tempo, por isso, de acordo com Garcia (2004), sua proposta, considerada idealista demais, não vingou em toda sua amplitude. Apesar do anteprojeto de Mário de Andrade constituir o alicerce do Decreto Presidencial $\mathrm{n}^{\circ}$. 25 de 30 de novembro de 1937, que orientou de forma jurídicoadministrativa o patrimônio e instituiu o tombamento, foi suprimida a parte relativa ao que hoje denomina-se bens culturais imateriais. $\mathrm{Na}$ época, mesmo propondo-se o Livro de Tombo Etnográfico pouca coisa foi feita neste sentido. Portanto, pode-se inferir que o Decreto $\mathrm{n}^{\circ}$. 3.551 de 4 de agosto de 2000, que hoje institui o Registro de Bens Culturais de Natureza Imaterial ressurge de uma lacuna provocada na própria origem da institucionalização do patrimônio. "Preterido diante do Decreto n'. 25 de Rodrigo Mello Franco de Andrade, que restringe o conceito de patrimônio ao conjunto de bens materiais móveis e 
imóveis, a concepção de um patrimônio imaterial enquanto semente não germina naquele momento, mas também não morre" (Medeiros, 2004:43).

Outro momento histórico-político que merece atenção são os tempos marcados pelo fim do regime militar no Brasil. De acordo com Garcia (2004), é possível perceber principalmente os tempos de "abertura" política como uma "fase axial nas políticas de cultura em geral e de patrimônio cultural, em especial", acrescentaria também o mesmo contexto ao desenvolvimento do turismo brasileiro, sendo que as duas políticas remetem sua fecundação em meio a este processo político. "Isso porque esse momento de transição democrática enseja a participação popular na formulação de políticas e, com isso, a definitiva organização e legitimidade dos movimentos sociais representativos das minorias sociais e étnicas no Brasil", conclui Garcia (2004:49). Portanto, em se tratando de políticas públicas de patrimônio imaterial e de turismo, talvez tenha sido neste período que se forjou a atual conjuntura política onde as duas encontram hoje ressonância.

\subsection{O decreto que institui o registro do patrimônio imaterial - 2000}

O Decreto $n^{\circ} 3.551$ de 4 de agosto de 2000 (anexo A), que institui o Registro de Bens Culturais de Natureza Imaterial e cria o Programa Nacional do Patrimônio Imaterial é sem dúvida a concretização do plano das idéias presentes em Mário de Andrade nos anos 30, refletidas em Luis Câmara Cascudo e Aloísio Magalhães, abarcando muitos folcloristas e antropólogos. É também resultado de um processo construído ao longo dessas 8 décadas, com especial efervescência entre os anos 70 e 80, quando encontrou maior repercussão nacional e internacional, sendo que nesse período ações mundiais bastante significativas sedimentaram uma noção mais ampla de patrimônio cultural.

No cenário internacional, essa preocupação com a preservação e a valorização das expressões da chamada cultura tradicional e popular surgiu mais fortemente logo após a Convenção da UNESCO sobre Salvaguarda do Patrimônio Mundial, Cultural e Natural, em 1972, definindo o patrimônio mundial em termos de bens móveis e imóveis, conjuntos arquitetônicos e sítios urbanos ou naturais. Em reação, um grupo de países, liderados pela Bolívia, 
solicitou junto a UNESCO a proteção às manifestações da cultura tradicional e popular como importante aspecto do Patrimônio Cultural da Humanidade. Efetivamente, somente veio uma reposta em 1989, quando a UNESCO lança a "Recomendação sobre a Salvaguarda da Cultura Tradicional e Popular" documento que aponta formas jurídicas que até hoje fundamentam as ações de preservação do que passou a denominar patrimônio cultural "imaterial" ou "intangível". Embora a percepção oriental sobre a proteção a essas expressões já fosse uma realidade nos 50, e atualmente contribua na relativização dessas questões no mundo ocidental, as primeiras iniciativas emergem mesmo após este debate (Fonte: Relatório do Grupo de Trabalho Patrimônio Imaterial (GTPI) - IPHAN, 2000).

No Brasil, o novo conceito incorporou-se legalmente à noção de patrimônio cultural a partir da promulgação da Constituição Federal de 1988, delineando uma nova instrumentalização política de toda uma produção que segundo Londres (2004:20), "nem sequer era considerada na sua dimensão cultural, como as criações científicas e tecnológicas, formas de expressão, e os modos de criar, fazer e viver". É essa conquista de espaço entre algumas preciosas linhas da legislação maior que inaugura um novo processo de valorização dos bens de natureza imaterial como patrimônio e ressalva a necessidade de outras formas de acautelamento e de preservação a formas de expressão e modos de criar, fazer e viver, às quais o tombamento é inadequado.

Conforme expresso no artigo 216 da Carta Magna:

"Constituem patrimônio brasileiro os bens de natureza material e imaterial, tomados individualmente ou em conjunto, portadores de referência à identidade, à ação, à memória dos diferentes grupos formadores da sociedade brasileira, nos quais incluem:

I - as formas de expressão;

II - os modos de criar, fazer e viver;

III - as criações científicas, artísticas e tecnológicas;

IV - as obras, objetos, documentos, edificações e demais espaços destinados às manifestações artístico-culturais;

$V$ - os conjuntos urbanos e sítios de valor histórico, paisagístico, artístico, arqueológico, paleontológico, ecológico e científico".

No plano das idéias, a discussão é retomada na década de 70 , pelo Centro Nacional de Referência Cultural (CNRC), e posteriormente pelo 
Fundação Nacional Pró-Memória (FNPM), nos anos 80, depois disso, a questão só volta ao centro dos debates patrimoniais, na segunda metade dos anos noventa. "É aqui que um renovado interesse em torno da questão a legitima e transforma, a partir de regras próprias, em um "campo", tal qual definido por Bourdieu." (Medeiros, 2004:43).

No dossiê final das atividades do GTPI, Márcia Sant'Anna (2000:11) ressalta que "o reconhecimento do papel das expressões populares na formação de nossa identidade cultural faz parte do próprio contexto de criação do IPHAN". Quase como uma forma de completar uma obra inacabada, é que coincidentemente por ocasião do $60^{\circ}$ aniversário do IPHAN, em 1997, e também no intuito de retomar essa vertente, já presente nos trabalhos do CNRC e FNPM (ambas instituições dirigidas por Aluísio Magalhães), é que se realiza o seminário internacional: PATRIMÔNIO IMATERIAL E FORMAS DE PROTEÇÃO, em Fortaleza, e com essa mesma finalidade, em 1998, institui-se a Comissão e Grupo de Trabalho que durante dois anos de pesquisa instruiu a proposta que originou o decreto.

A Carta de Fortaleza, documento final produzido pelo seminário, é considerada uma retomada histórica da discussão sobre valorização da cultura popular e tradicional. É a Carta que vislumbra o momento de uma "crescente demanda social pelo reconhecimento e preservação do amplo e diversificado patrimônio cultural brasileiro, encaminhada pelos poderes públicos e pelos segmentos sociais organizados", informa o Relatório do GTPI (2000).

Também no ano de 1997 é lançado o Programa Nacional de "Turismo Cultural", sinalizando um início da legitimação da relação e diálogo entre os "campos" (Bourdieu, 1989), possibilitando a interface das políticas. O Programa Nacional Turismo Cultural, resultou da parceria entre o Ministério da Cultura, Secretaria de Comunicação da Presidência da República, Ministério da Indústria, Comércio (e Turismo), EMBRATUR, prefeituras e iniciativa privada. Lançado em Diamantina, no dia 16 de agosto de 97, a meta principal era criar condições para o desenvolvimento do turismo em cidades históricas do interior do país.

Do decreto para cá, somam-se cinco anos, nesse período seis bens culturais de natureza imaterial foram registrados: Arte Kusiwa, Samba de Roda no Recôncavo Baiano, Ofício das Paneleiras de Goiabeiras, Círio de Nossa 
Senhora de Nazaré, Acarajé, Viola-de-cocho. Veja a situação atual dos processos no Iphan até o dia 30/05/2005, publicados no site oficial:

Tabela 1: Processos do Patrimônio Imaterial - Iphan.

\begin{tabular}{|l|r|}
\hline - Bens registrados & 6 \\
\hline - Processos de registro em andamento & 9 \\
\hline - Inventários realizados & 4 \\
\hline - Inventários em andamento & 25 \\
\hline
\end{tabular}

Fonte: Almeida (2005), a partir de dados coletados no trabalho de campo junto ao Iphan.

Segundo Garcia (2004), a atual gestão de Gilberto Gil, no Ministério da Cultura (MinC) tem se mostrado empenhada em promover a política de patrimônio imaterial, procurando desenvolver formas de apoio e de financiamento para o setor, via leis de incentivo e por meio do plano plurianual do Governo Federal. O pesquisador sublinha que há interesses do governo de colocar em evidência essa política, atendendo a agenda nacional e internacional.

No dia 16 de março de 2003, o Ministro da Cultura Gilberto Gil, empossou o novo presidente do Instituto do Patrimônio Histórico e Artístico Nacional - IPHAN, o antropólogo Antônio Augusto Arantes Neto, um dos principais expoentes do campo da cultura popular no Brasil. A posse emblemática é reveladora dessa orientação nos rumos do Governo Lula (2002atual). De forma inovadora, o MinC cria a Secretaria da Diversidade Cultural, comanda pelo ator Sérgio Mamberti, também defensor das manifestações da cultura popular. É criado também o Departamento do Patrimônio Imaterial (DPI), no IPHAN, que tem implantado uma política para os bens imateriais, como inventários, processos de registro e planos de salvaguarda sobre 0 conhecimento tradicional. Em fevereiro de 2005, o presidente do IPHAN cria a Câmara do Patrimônio Imaterial, que constituiu junto ao Conselho Consultivo a Câmara Técnica do Patrimônio Imaterial, com a finalidade de colaborar na formulação e implantação da política de registro do patrimônio cultural de natureza imaterial. Entre suas principais atribuições, a Câmara formulará critérios para avaliar a pertinência e a prioridade das propostas de registro de 
bens imateriais, além da proposta de detalhamento dos processos de registro e dos parâmetros para a realização dos registros audiovisuais que acompanham os processos, a política de conservação da documentação dos processos, os indicadores do impacto do registro sobre o bem cultural e a revisão dos processos de registro após dez anos.

Depois de 20 anos de criação do Ministério da Cultura, foi aprovada pela primeira vez, no dia 01 de Junho, no Senado Federal, a Proposta de Emenda Constitucional (PEC) que prevê a criação do Plano Nacional de Cultura, moldando mais um novo instrumento legal que resultará na Lei Geral da Cultura. A lei deve ser promulgada pelo Congresso Nacional até o final do mês de agosto. Se essas ações forem bem planejadas e dialogadas sob uma perspectiva transversal, que leve em conta a cidadania, a inclusão, a sustentabilidade e, principalmente, o respeito, muito corroborará para a construção do direito previsto no art. 215, da Constituição Federal: "O Estado garantirá a todos o pleno exercício dos direitos culturais e o acesso às fontes da cultura nacional, e apoiará e incentivará a valorização e a difusão das manifestações culturais".

Parece existir, então, um campo em construção favorável, tanto do ponto de vista de instrumentos jurídicos que estão em fase de elaboração quanto de capital humano envolvidos com a defesa e preservação das práticas culturais brasileiras, especialmente as vertentes da cultura popular. O futuro dessas questões depende deste processo que está sendo confeccionado.

\subsection{A criação do Ministério do Turismo (MTur) - 2003.}

A eleição histórica do candidato a presidente Luis Inácio Lula da Silva, em outubro de 2002, sinalizou uma arena política de mudanças para o Brasil. Um clima de ansiedades e expectativas tomou conta do país. Com o apoio de quase 53 milhões de eleitores, tornou-se o presidente da República que obteve mais votos em toda a história do Brasil e o segundo mais votado do mundo. Pela primeira vez na história do país um candidato de um partido de oposição, não indicado pelas elites brasileiras e vindo do movimento sindical foi eleito para ocupar o posto mais alto do poder público nacional. 
Na ocasião, o cientista político Túlio Velho Barreto, escreveu o artigo: As eleições de 2002 e seus significados, sentenciando que "agora, só o tempo dirá se o PT (ou seu governo) avançará na direção do Estado de bem-estar social, realizando, enfim, a tão esperada e necessária inclusão social, ou se ficará restrito a políticas sociais compensatórias de alcance apenas emergencial. Mas, aí, já se trata do governo e não do significado da vitória eleitoral". Vamos nos ater neste estudo no clima gerado pelo resultado destas eleições, sem mais aprofundamento sobre o que tem sido o governo, considerando que significado e realidade não são sinônimos. É em meio a esta rede de significados que pela primeira vez na história do país o turismo passa a ter um Ministério voltado especificamente para o desenvolvimento do setor, deixando de ser um apêndice de outros ministérios, como era anteriormente ligado Ministério do Esporte (e Turismo).

Quando ainda candidato à presidência da república, o atual Presidente Lula já manifestava publicamente a importância que daria ao turismo em sua gestão, caso fosse eleito. Segundo os pesquisadores Sansolo e Cruz (2003), a criação do Ministério do Turismo em 01/01/2003 por meio da Medida Provisória no 103 , no primeiro dia de mandato, é "emblemática do status conferido por este governo ao turismo na administração pública federal":

\section{MEDIDA PROVISÓRIA № 103, DE 30 DE DEZEMBRO DE 2003}

Publicada no D.O.U. de 1º. 01.2003 (Edição Especial)

Dispõe sobre a organização da Presidência da República e dos Ministérios, e dá outras providências.

CAPÍTULO II-

DOS MINISTÉRIOS

Seção I - Da Denominação

Art. 25. Os Ministérios são os seguintes:

XXIII - do Turismo:

Seção II - Das áreas de competência:

XXIII - Ministério do Turismo:

a) política nacional de desenvolvimento do turismo;

b) promoção e divulgação do turismo nacional, no País e no exterior;

c) estímulo às iniciativas públicas e privadas de incentivo às atividades turísticas;

d) planejamento, coordenação, supervisão e avaliação dos planos e programas de incentivo ao turismo. 
Três meses depois, lançou-se o primeiro documento de caráter generalizante voltado à organização e ao desenvolvimento do setor do turismo no Brasil, o Plano Nacional de Turismo (PNT): 2003-2007. Conforme Sansolo e Cruz (2003), considerando o curto interregno de tempo entre a criação do Ministério do Turismo, a organização da administração pública federal de um modo geral e o lançamento oficial do referido Plano, pode-se inferir a clara prioridade que tem o turismo nesta administração. "Esse novo status adquirido pelo turismo na administração pública federal é de certa forma um reflexo da crescente importância e reconhecimento desta atividade, por sua capacidade de dinamizar diversos setores produtivos, gerar riqueza, renda e empregos".

O turismo passou a ser anunciado entre o ranking das 10 prioridades do governo federal, segundo declaração do atual Ministro do Turismo, o deputado mineiro Walfrido Mares Guia, em uma sessão solene, na Câmara dos Deputados, em comemoração, ao Dia Mundial do Turismo, comemorado pela primeira vez no Brasil no dia 27 de setembro de 2004. A data passa a ser institucionalizada, sob o tema escolhido pela Organização Mundial de Turismo (OMT) "Desporto e Turismo: duas forças vitais para a compreensão mútua, a cultura e o desenvolvimento dos países".

No Brasil, a Semana do Turismo foi comemorada com uma série de eventos. Os organizadores da semana escolheram o presidente Luiz Inácio Lula da Silva como principal personalidade do turismo em 2004, pela criação do Ministério do Turismo. De acordo com o presidente da Confederação de Trabalhadores em Turismo e Hospitalidade, Moacir Tesch, o setor está recebendo um incentivo maior com a criação da nova pasta. "Para os trabalhadores em turismo e hospitalidade foi uma grande conquista a criação do Ministério do Turismo. Era uma antiga reivindicação do setor. O turismo no Brasil está voltando a se desenvolver e, com o apoio do governo, nós vamos responder com a criação de empregos, geração de renda e riquezas para o país", afirmou Tesch em entrevista a um Jornal de Turismo: Notícias FUNIBER, da Fundación Universitaria Iberoamericana. De acordo com Sansolo e Cruz (2003), "em tempos de globalização, de desemprego estrutural, de crescimento da pobreza, o setor serviços e, inserido nele, o turismo, tem jogado um papel cada vez mais importante para as sociedades". 
A atividade de turismo engloba 52 setores no Brasil. O Banco Central divulgou que, de janeiro a julho de 2004, a receita líquida no setor foi de U\$ 345 milhões. Essa receita é sete vezes maior do que a registrada no mesmo período no ano passado. Nesses sete primeiros meses do ano de 2005, por exemplo, turistas estrangeiros deixaram US\$1,84 bilhão no Brasil, cifra 40,46\% maior do que em 2003. O gasto de brasileiros no exterior também aumentou em 18,91\% para o período, quando foram desembolsados US\$1,5 bilhão em viagens internacionais. "Estes números mostram não só o resultado da promoção do turismo brasileiro no exterior, mas que a economia do Brasil está melhor, já que nós também aumentamos nossos gastos lá fora", observa Eduardo Sanovicz, atual presidente da Embratur, em entrevista para a revista eletrônica Panorama Brasil.

Por sinal, não é possível falar da história do turismo no Brasil sem retomar a história da EMBRATUR, e segundo o pesquisador Santos Filho (2005), esse entendimento não pode ser feito fora da contextualização histórica, isto é, desconsiderando o período da ditadura militar. Até a criação da EMBRATUR, em 18 de novembro de 1966, pouco havia em termos de planejamento da atividade turística, na época, o Ministro da Indústria e do Comércio, Paulo Egydio Martins, apresentou a $1^{\mathrm{a}}$ Exposição de Motivos para a criação do órgão, bem como Projeto de Lei, ao Presidente da República, Humberto de Alencar Castelo Branco. Já na exposição foi indicada a contribuição para a economia nacional que o turismo traz, enquanto fonte de geração de divisas e empregos. Antes disso, pode-se identificar apenas a elaboração de algumas leis desconexas, restritas a aspectos parciais da atividade, como a regulamentação de agências de viagem e de turismo. Aquele momento, a divisão de Turismo e Certames, então pertencente ao Ministério da Indústria e do Comércio e encarregada dos assuntos do turismo, não podia mais atender as necessidades de expansão da indústria do turismo. A EMBRATUR passou à condição de instituto em 28 de março de 1991, quando adotou a denominação atual.

O primeiro presidente da Embratur ficou à frente do órgão de 1966 a 1971, com indicação feita pela Associação Comercial do Rio de Janeiro, o carioca Joaquim Xavier da Silveira, secretário de Comércio do Ministério da Indústria e Comércio. Sua administração passou pelos governos de Humberto 
Castelo Branco (15/04/1964 a 15/03/1967), Costa e Silva (15/03/1967 a 31/08/1969) e pela junta militar, que durou dois meses, e parte do governo de Emilio G. Médici (30/10/1969 a 15/03/1974). Foi na referida gestão que o governo classificou a atividade do turismo como indústria. Segundo Santos Filho, motivos que ainda estão em fase de estudos vêm apontando que a preocupação com o turismo nesse período, estava vinculada originalmente à necessidade da divulgação de uma imagem que contrapunha a da ditadura militar, a perseguição política e ideológica à população, como também, o desrespeito aos direitos humanos. Segundo o pesquisador, foi com esse intuito que o regime político brasileiro cria imediatamente a Embratur, que em conjunto com o Ministério das Relações Exteriores, procurou mudar a imagem do país no exterior. "Tal iniciativa se manifesta por meio da criação de mensagens publicitárias, passando a idéia de um país de eterna alegria, carnaval, sol, mulheres sensuais e de país exótico, isso tudo apoiado nos disputados escritórios da Embratur nos Estados Unidos, na Inglaterra, na França e na Alemanha", identifica Santos (2005).

O instituto serviu como incubadora das principais idéias que nortearam a criação do atual Ministério do Turismo. Foram os projetos e experiências acumuladas pela EMBRATUR ao longo do tempo, que constituíram a base e o suporte técnico para a nova política de turismo no Brasil.

Nesse contexto, o Plano Nacional de Turismo, lançado oficialmente em 29/04/2003, pode ser entendido como herdeiro da experiência da EMBRATUR, no entanto, mesmo oferecendo uma ampliação e remodelação da política pública federal para o desenvolvimento do turismo, ainda carrega, pelos estudos preliminares de Santos Filho (2005) a mesma tentação de dar prioridade e privilégios para o turista estrangeiro, o que segundo o autor permanece nos planos de turismo elaborados pela Embratur desde 1966. Para isso, o autor observa que as regras e a hospitalidade exigida pelo capital são ditadas em "detrimento do turista nacional que se submete a uma hospitalidade globalizada, na qual a idiossincrasia do brasileiro não participa". O pesquisador lamenta que mais uma vez, a proposta inicial dos planos nacionais destaque 0 turismo receptivo como a ênfase principal e de importância fundamental para qualquer política de turismo. "Padronizou-se a idéia positivista de que o turismo 
só existe quando aparece o turista estrangeiro", contextualiza Santos Filho (2003).

Nessa nova configuração a EMBRATUR, passou então a cuidar exclusivamente da promoção, marketing e apoio à comercialização dos produtos, serviços e destinos turísticos brasileiros no exterior. Tudo o que concerne ao turismo doméstico (cadastros de empresas prestadoras de serviços turísticos, de guias e de bacharéis; políticas públicas; fomento; regulamentação; normatização; promoção interna etc) é de responsabilidade do Ministério do Turismo, diferenciação encontrada no site oficial do Ministério do Turismo: www.turismo.gov.br.

A valorização do turismo tem motivado uma reação especialmente positiva pela sociedade e parcialmente favorável à implementação do Plano Nacional do Turismo, porém, Sansolo e Cruz (2003) advertem que é necessário uma apreciação crítica deste momento da ação pública relativa ao turismo no Brasil e de seu principal instrumento, o PNT, no sentido de contribuir com a construção de um conhecimento crítico sobre o planejamento governamental e a política pública do turismo no Brasil, a partir de um documento central neste processo, como é Plano Nacional de Turismo. No capítulo três trataremos mais especificamente do Plano Nacional do Turismo. 


\title{
2. (Pós) modernidade (s): o presente senso de complexidade e fragmentação
}

\author{
“Como implantar um sistema sustentável de \\ proteção ao patrimônio imaterial num processo \\ onde a globalização é, ao mesmo tempo, \\ ameaça e estímulo? \\ Uma força propulsora e uma força destruidora. \\ o bem e o mal. \\ O diverso e o igual " (Joaquim Falcão, 2001:164).
}

A alusão acima exprime e sintetiza a inspiração que norteou este estudo. O capítulo procura situar a temática entre os paradigmas da pósmodernidade e da globalização. Propõe-se uma reflexão sobre a inter-relação entre conceitos fragmentados, exaltados diante da complexidade dos tempos "(pós) moderno (s)", quase como uma necessidade, imposta ou não, de segmentar, fragmentar, separar, detalhar, de contrapor a ordem (predominante), e que não deve ser entendida como unidade. Para efeitos desse estudo, unidade é aqui compreendida como o todo que une as partes, que une o igual (o eu, a homogeneidade) e o desigual (o outro, a heterogeneidade), o caos e a ordem, o nexo e o desconexo. Magnetizados por uma força que em termos relacionais acaba por arranjar o mosaico complexo, que de forma não estática, em um ambiente mutável e incerto, conduz à organização e à alteridade.

Vive-se um momento de desconstrução ${ }^{2}$ nos termos de Derrida (1971), de "desmanche" e de desfazer as unidades culturais, por Featherstone (1997).

\footnotetext{
${ }^{2}$ Desconstrução (do francês, déconstruction), conceito criado por Jacques Derrida em: A Escritura e a Diferença, São Paulo, Perspectiva , 1971 (original francês de 1967) que traz a reflexão de que tudo é uma construção ideológica, que tenta "passar por natural e inevitável o que é na verdade o produto de uma cultura ou de um sistema de pensamento particular" Trigo (2004). A desconstrução estaria em curso e toda a história do mundo se desconstrói por si mesma, o que faz com que se possa interrogar a história e, ao mesmo tempo, tentar transformá-la, contribuindo com um processo em movimento (Dias, 2004).
} 
Este pensador observa que:

"A crença confiante em uma vida social ordenada, conjugada a um progresso que se ampliava cada vez mais, parece ter alcançado seus limites e uma reversão ocorreu. Em decorrência, os teóricos pós-modernos enfatizaram a fragmentação em contraposição à unidade, a desordem em contraposição à ordem, o particularismo em contraposição ao universalismo, o sincretismo em contraposição ao holismo, à cultura popular em contraposição à alta cultura e o localismo em contraposição ao globalismo" (Feartherstone, 1997).

É a partir deste cenário dicotomizado que trilha-se o caminho teórico desta pesquisa, visitando conceitos quase sempre recortados que muito refletem o momento que vivemos, de fragmentação. No entanto, a pesquisa esforça-se em considerar na congruência e no diálogo a bússola orientadora àqueles que pretendam seguir essa senda: os acadêmicos, os técnicos, especialistas, planejadores de políticas públicas, enfim, todos os envolvidos neste processo de construção do desenvolvimento do turismo no Brasil.

Assim como o universo pressupõe uma certa organização e o equilíbrio se faz de forças complementares, por vezes contrárias, esses conceitos carregam uma atração indissociável. Global X Local, Patrimônio Imaterial $x$ Material, Cultura Popular $\times$ Cultura Erudita, Turismo X Viagem. Diante de tantas idéias fragmentadas e da reflexividade a que todas são submetidas "o que parece claro é que não é proveitoso encarar o global e o local como dicotomias separadas no espaço e no tempo. Ao que tudo indica, os processos de globalização e localização estão inextricavelmente ligados na atual fase". (Feartherstone, 1997). Se incluirmos as dicotomias citadas acima junto à observação de Feartherstone, a assertiva continuaria igualmente válida, pois é de idéias indissociáveis que se fala. E é a partir daí que este estudo fala. De um tempo pós-moderno que não é progressivo, um tempo múltiplo, superposto, transversal, onde as dicotomias são conduzidas ao diálogo e a relação, no campo de lutas simbólicas, de hibridismos, de múltiplas vozes, às vezes, até mesmo de confronto.

De acordo com Feartherstone (1997) os "processos de desdiferenciação, de reeterogeneização e de reimersão no cotidiano surgem com grande proeminência nos movimentos contraculturais, tais como 0 romantismo e o pós-modernismo". A diferença já não é mais tão demarcada, 
instaura-se uma prática mais voltada para a conexão das coisas, para uma perspectiva transversal e transdisciplinar. O turismo não está deslocado dessa realidade, está imerso, moldando suas práticas na modernidade, e assim vai sendo instaurado como prática social legitimada. "Uma das características distintivas da modernidade, de fato, é a crescente interconexão entre dois "extremos" da extensão e da intencionalidade: influências globalizantes de um lado e disposições pessoais de outro" (Giddens, 2002:9). Aqui, o autor chama a atenção à reflexividade a partir da esfera da intimidade, a teoria do "eu reflexivo" de Giddens (2002) direciona a discussão ao amplo campo relacional a que a modernidade e a globalização expõem as coisas, especialmente ao âmbito do indivíduo, que constantemente é instigado, estimulado a fazer escolhas. Tal fato, nem sempre é tranqüilo, causando, às vezes, um grande desgaste e sentimento de vazio. Seria um tipo de hiper-estimulação.

As reflexões de Featherstone (1997) pontuam uma linha tênue entre a modernidade e a pós-modernidade, no entanto, não balizam uma como fim da outro, pelo contrário, sua obra apresenta uma diversidade de referenciais teóricos, visitando grandes estudiosos da modernidade e pós-modernidade como Giddens, Habermas, Bauman, Baudelaire, Osborne, Urry, Sakai, entre outros. Com uma certa inclinação a suscitar polêmicas, o teórico tende a diferenciar um de outro contextualizando que "o projeto da modernidade passou a ser ameaçado ou exaurido por fatos ocorridos na esfera cultural, os quais testemunharam o desenvolvimento de uma aliança entre cultura de consumo e modernismo" (Feartherstone, 1997). Isso fica ainda mais claro, quando cita as idéias de Zygmunt Bauman (1991) observando que este lê a modernidade do ponto de vista da teoria pós-moderna. Featherstone sintetiza as principais idéias de Bauman, apresentando que a modernidade é uma época em que se vê, refletidos nela, o ordenamento da natureza, o mundo social e o self e as conexões entre os três.

"No entanto a busca da ordem precisa defrontar-se com o conceito daquilo que é o oposto da ordem: o caos. Nesse sentido, somos ameaçados pela incoerência, incongruidade, irracionalidade, ambigüidade, contingência, polissemia, confusão e ambivalência. A consciência moderna é governada pelo impulso de ampliar, de mapear e de classificar, o que significa que ela tem de descobrir ou revelar camadas de caos, sempre mais novas, 
por debaixo da ordem que constrói, a fim de alimentar uma inquietação..." (Bauman apud Featherstone 1997:197)

Featherstone (1997), faz uma análise interessante das discussões de Giddens sobre a questão tempo-espaço, ressaltando que a dimensão espacial da modernidade, por vezes, é subestimada. Segundo ele, precisa-se formular a indagação sobre esta dimensão em termos de uma lógica superior, que emana do centro ocidental, e em termos do relacionamento espacial do não-Ocidente com o Ocidente.

"Trata-se de termos que implicam relacionamentos de poder, não mais possíveis de descartar o desenvolvimento de modernidades globais, no plural. A modernidade não deveria então ser vista exclusivamente em termos temporais, como uma época, mas também em termos espaciais e relacionais" (Featherstone, 1997). Grifos meus.

Como o cerne principal desta discussão é outro, limita-se aqui somente pincelar o tempo e o espaço onde se insere atualmente a discussão sobre Patrimônio Imaterial e Turismo, neste contexto da pós-modernidade, quer seja entendido como uma expansão da modernidade, a qual Giddens (2002) chama de "alta modernidade" e Bauman (2001) de "modernidade líquida"; quer como um novo período, que sinaliza o fim da modernidade. Sendo importante entender o turismo como invenção legitimada e regulada pela lógica do mundo globalizado e pós-moderno, inserido neste contexto relacional contrariando de certa forma a perspectiva linear de que a modernidade do ocidente, especialmente a modernidade americana ditaria o caminho do mundo pósmoderno e globalizado. De acordo com Featherstone já não é mais fácil para as nações ocidentais manter a superioridade de adotar uma missão civilizatória em relação ao resto do mundo, na verdade esta imagem está sendo contestada e desafiada, surgindo a necessidade de o Ocidente ser cada vez mais forçado a ouvir, relacionar e dialogar com o não ocidente.

Portanto, contraditoriamente, é dentro deste contexto que ameaçava à homogeneização que a globalização revela novos níveis de diversidade e heterogeneidade, onde "os sincretismos e hibridismos constituem mais a regra do que a exceção". (Feartherstone, 1997) 


\subsection{Turismo uma invenção legitimada nos tempos modernos}

Considerado o maior fenômeno de deslocamento voluntário da história da humanidade, o turismo faz parte das necessidades inventadas pelo mundo moderno, um fenômeno histórico e social sem precedentes (Barreto:2003; Coriolano:2000; Siqueira:1998; Urry:2000, entre outros).

Para a Organização Mundial do Turismo, OMT, turismo compreende as atividades de pessoas que viajam para lugares afastados de seu ambiente usual, ou que neles permaneçam por menos de um ano consecutivo, a lazer, a negócios ou por outros motivos. Segundo dados da OMT, o turismo tornou-se um dos principais setores socioeconômicos mundiais e um dos componentes líderes do comércio internacional. Até o ano de 2020, a OMT calcula que haja cerca de 1,6 bilhão de chegadas de turistas internacionais e que a receita turística internacional atinja 2 trilhões de dólares. Por chegadas internacionais entende-se o total de viajantes de turismo internacionais. Estima-se que o turismo doméstico seja cerca de 10 vezes maior que o turismo internacional. Por doméstico, entende-se aquele turismo realizado para dentro do próprio país, perspectiva um pouco relegada pelo desenvolvimento do turismo no Brasil que tem privilegiado nas campanhas e políticas públicas o enfoque no turista estrangeiro, diferente, de países, como os EUA, que investem massivamente em seu público interno estimulando as viagens consideradas de curta distância.

No Brasil, recente pesquisa conduzida pela FGV (Fundação Getúlio Vargas, 2005) em parceria com a Embratur sustenta essa visão otimista do setor em relação ao desempenho do Plano Nacional do Turismo (mais detalhes no capítulo de análise sobre o plano). A pesquisa mostrou que o total de passageiros desembarcados em vôos internacionais alcançou, nos 12 meses terminados em abril (2005), 6,5 milhões, apontando um crescimento de $16 \%$ em 2003 e 14,2\% em 2004. (O total inclui desembarques de estrangeiros no Brasil e de brasileiros que retornam ao país). O total de passageiros em vôos domésticos também subiu de 19,2\% no ano passado e somou 38,8 milhões nos 12 meses encerrados em abril. 
A partir do séc. XIX, segundo Barreto (2003), o turismo passou a ser a forma mais procurada de lazer, e na atualidade, fazer turismo tornou-se uma aspiração de todos os incluídos na sociedade global de consumo, conferindo grande status. Em entrevista concedida para esta pesquisa, a diretora do Departamento do Patrimônio Imaterial - Iphan/MinC, Márcia Sant'Anna, observou que um novo tipo de turista vem se delineando ao longo da evolução do turismo, o turista contemporâneo, formatado por práticas globalizadas ele realiza um turismo menos atrelado ao lazer e mais relacionado a questões globais, que envolvem trabalho, relações internacionais e de intercâmbio.

Para Deis Siqueira, em seus estudos: Turismo na Encruzilhada, livro ainda no prelo é fundamental compreender a separação que se dá no capitalismo entre tempo de trabalho e tempo livre, instaurando-se aí as bases para o desenvolvimento de uma "indústria do turismo". A partir de uma reflexão sociológica, a pesquisadora afirma que "o turismo, tal como concebido na atualidade, tem sua origem na própria concepção capitalista da vida. Uma criação da sociedade de consumo, que a partir da importância do lazer na sociedade atual, passa a vender o turismo ou a comercializar a viagem como um novo produto, nos moldes de uma sociedade de consumo, atrelado, portanto às leis de mercado". Essa mesma posição encontra eco em Coriolano (1998) que define o turismo como uma forma elitizada de lazer. "É uma modalidade de entretenimento que exige viagem, deslocamento de pessoas, consumo do tempo livre" (Coriolano, 1998:115).

John Urry também direciona a discussão do turismo aos aspectos do lazer na sociedade contemporânea, o que chama de lazer enquanto turismo. Urry (2002) revela o "desinteresse" que a maioria dos estudiosos têm dado ao turismo, as férias e as viagens como fenômeno social extremamente significativo. "Conferir um sentido teórico à "diversão, ao prazer e ao entretenimento" revelou-se uma tarefa difícil para os cientistas sociais", pois existe pouca fundamentação na sociologia do turismo. O autor situa o turismo como atividade de lazer, e enquanto tal, assim como Dumazedier (2000), pressupõe seu oposto, no trabalho regulamentado e organizado. Dumazedier ressalta que o lazer tem ocupado espaço de grandes conquistas na vida, Urry faz o mesmo, ao dizer que "ser turista é uma das características da experiência moderna, não viajar é como não possuir um carro ou uma bela casa" (Urry, 
2002:19). O lazer e o viajar conferem status e carregam uma forte idéia de saúde na sociedade moderna.

Balducci (2003) recorre a Urry, Guiddens e Labate para justapor os conceitos de viagem e turismo, os autores concordam que a viagem - e sua modalidade moderna, o turismo - está cada vez mais "regulada pela lógica do mundo globalizado que, entre outros fatores, mediatiza, por meio da imagem, as culturas e a natureza, transformando-as em mercadoria".

O turismo pressupõe o não-cotidiano, o que promove um novo olhar distante das paragens conhecidas, às vezes nem mais percebidas, o olhar do turista, que conforme Urry busca um conjunto de diferentes cenários, paisagens, ou vistas de cidades, que se situam fora daquilo que é comum. "Estes lugares provocam rupturas com rotinas e práticas estabelecidas no diaa-dia".

A complexidade envolve todo o processo turístico, muitas variantes entram em jogo, conflito de interesses, fatores econômicos, sociais, ambientais, até mesmo o olhar do turista é também complexo e não existe uma experiência universal para todos.

"Não existe um único olhar do turista, ele varia de acordo com a sociedade, o grupo social e o período histórico. Tais olhares são construídos por meio da diferença. Esse olhar pressupõe um sistema de atividades e signos sociais que localizam determinadas práticas turísticas, através dos contrastes implicados com práticas não turísticas, sobretudo as baseadas no lar e no trabalho", analisa Urry (2002).

Balducci (2003) ressalta ainda que os teóricos do turismo, particularmente aqueles que analisam do ponto de vista das ciências sociais, concordam, pelo menos, com esse aspecto: "O turismo é um fenômeno extremamente complexo, mutável, que opera múltiplas formas e nas mais diversas circunstâncias, sendo difícil apreendê-lo, em sua totalidade, por meio de uma única perspectiva teórica ou mesmo de uma única ciência" (Balducci, 2003). Portanto, a interdisciplinaridade deve caracterizar a base para qualquer discussão acerca do turismo, relacionando cultura, economia, história, geografia, arquitetura, comunicação (destaque para a informação e interpretação dos bens culturais), sociologia, antropologia, administração e principalmente a comunidade, parte integrante do "lugar" onde se insere todo o 
processo de implementação turística. O presente estudo considera esse viés, mas acaba por sofrer algumas limitações dando maior ênfase aos aspectos da relação entre cultura e turismo, contudo faz-se necessário a ponderação de que o assunto é um processo em construção e exige uma abordagem transdisciplinar.

A esse respeito, destaca-se o que diz o autor a seguir:

"A cultura é sem dúvida, a mais forte representatividade de um local para que possamos conquistar uma atividade turística. $O$ turismo, na sua evolução histórica, sempre procurou retratar a cultura como base de vivência e sobrevivência do ser humano". (Beltrão, 2001:83).

Isto quer dizer que não se pode tratar o turismo de forma isolada, descolado do contexto social e cultural, é nesse sentido, que esta pesquisa caminha para a relação intrínseca entre cultura e turismo, especialmente patrimônio imaterial e turismo, e à análise de como tem sido tratada essa relação nas políticas públicas federais. No entanto, antes de entrar no âmbito da congruência dos assuntos é importante situar o conceito de cultura.

\subsection{As noções de cultura}

De acordo com Featherstone (1997), o processo de globalização sugere simultaneamente duas imagens da cultura. A primeira pressupõe a extensão de uma determinada cultura (dominante) que incorpora e integra as outras até o seu limite, o globo. O que sugere um processo de conquista e unificação do espaço global. A segunda aponta para a compreensão das culturas. Coisas que eram mantidas separadas são agora colocadas em contato e justaposição. As culturas se acumulam umas sobre as outras, se empilham, sem princípios óbvios de organização.

São muitas as noções de cultura, mas a ascendência remete a duas concepções do termo, uma de origem filosófica e alemã (Kultur), e outra de origem antropológica e anglo-americana (culture). Ambas consolidaram seu significado teórico na segunda metade do século XIX. De acordo com os estudos de Laraia (2002) o termo germânico Kultur era utilizado para simbolizar todos os aspectos espirituais de uma comunidade, enquanto a palavra francesa Civilization referia-se principalmente as realizações materiais de um povo. 
Ambos os termos foram sintetizados por Edward Tylor no vocábulo inglês Culture, consolidando a primeira definição de Cultura, formulada do ponto de vista mais antropológico, como utilizado atualmente: "Cultura ou Civilização, tomados em seu mais amplo significado etnográfico são aquela totalidade complexa que inclui conhecimento, crença, artes, moral leis e quaisquer outras capacidades e hábitos adquiridos pelo homem enquanto membro da sociedade" (Tylor, 1871:1).

Norbert Elias (1994) procura também essa diminuição de barreiras entre os conceitos de Kultur e Civilisation, tratando-os de forma a aproximá-los com menos rigidez e sem estabelecê-los como "inequivocadamente opostos". A mesma aproximação faz João Quartim de Moraes em seu artigo: As formas culturais, a arte e a técnica no horizonte do século XXI, para ele a diferença de concepção pode se resolver em diferença de objeto. "Os correlatos objetivos de cultura e civilização seriam genericamente os mesmos, mas as duas categorias aplicar-se-iam, respectivamente, a sociedades "simples", outra a sociedades "complexas". Em léxico filosófico, cultura seria civilização em si e civilização, cultura para si" (Moraes, 2004).

Segundo o pesquisador Roque Laraia (2002), o conceito antropológico de cultura é tema central das discussões antropológicas nos últimos 100 anos, mas ainda tem se demonstrado um assunto inesgotável. Ele analisa que as centenas de definições formuladas após Taylor serviram mais para estabelecer uma confusão do que ampliar os limites do conceito. A grande importância, é que definitivamente, em 1871, o conceito de cultura afastou-se da biologia, passando a ser entendido como um comportamento apreendido, que independe de uma transmissão genética.

Assim de acordo com Laraia (2002):

"O homem é o resultado do meio cultural em que foi socializado. Ele é um herdeiro de um longo processo acumulativo, que reflete o conhecimento e a experiência adquiridos pelas numerosas gerações que o antecederam. A manipulação adequada e criativa desse patrimônio cultural permite inovações e as invenções. Estas não são, pois, o produto da ação isolada de um gênio, mas o resultado do esforço de toda uma comunidade".

No entanto, por mais que na vida acadêmica o conceito tenha se distanciado da biologia, conforme Laraia (2002), ainda prevalece no senso 
comum, entre os diferentes setores da população "a crença nas qualidades (positivas e negativas) adquiridas graças à transmissão genética", o que para ele talvez seja o ponto em que a noção antropológica de cultura mais contraria o pensamento leigo. "O perigo desses tipos de explicações é que facilmente associam-se com tipos de discriminação raciais e sociais, numa tentativa de justificar as diferenças sociais" (Laraia, 2002).

Em seus estudos, Laraia (2002) mostra que uma das tarefas da antropologia moderna tem sido a constante reconstrução do conceito de cultura, fragmentado por numerosas reformulações, podendo em linhas gerais ser agrupados em correntes. Para isso, utiliza-se do esquema elaborado por Roger Keesing em seu artigo "Theorias of Culture", no qual classifica as tentativas modernas de obter uma precisão conceitual. Laraia (2002) cita Keesing que inicialmente refere-se, às teorias que consideram a cultura como um sistema adaptativo... (Antes da continuidade, faz-se necessário um parênteses, para situar que essa explanação recorre-se aos estudos de Laraia (2002) somado as interpretações de Suassuna (2004) sobre Laraia (2002), sendo os grifos referentes às citações de Laraia) Para essa tendência a cultura se constitui como um conjunto de "sistemas de padrões de comportamento que servem para adaptar as comunidades aos seus embasamentos biológicos". A esse respeito Suassuna (2004), cita o exemplo dos estudos antropológicos neo-evolucionistas - como os realizado por Leslie White, que considera que a passagem do estado animal para o humano ocorreu quando o cérebro do homem foi capaz de gerar símbolos, ou seja, para perceber o significado de um símbolo é necessário conhecer a cultura que o criou. Assim, White definiu que "todo comportamento humano se origina no uso de símbolos. Toda cultura depende de símbolos" (Laraia (2002) cita White).

Em seguida, as teorias idealistas que consideram a cultura como objeto, que conforme Suassuna (2004: 167) "apresentam diferenças em suas formas de abordar tal conceito", sendo subdividas em 3 esferas: A cultura como sistema cognitivo, no qual se entende que "a cultura é tudo aquilo que o indivíduo tem de conhecer ou acreditar para operar de maneira aceitável dentro de sua sociedade". Depois, a cultura constituída por sistemas estruturais, que define "cultura como um sistema simbólico que é uma criação cumulativa da mente humana" (Laraia, 2002: 61), nesta vertente, situa-se as contribuições do 
antropólogo francês Lévi-Strauss. Por fim, a última abordagem considera que a cultura é como sistemas simbólicos, tendência liderada pelo antropólogo norteamericano Clifford Geertz. Citando Geertz (1989) Suassuna (2004: 168) ressalta que a cultura deve ser considerada "não como um complexo de comportamentos concretos, mas como um conjunto de mecanismos de controle, planos, receitas, regras, instruções (que os técnicos de computadores chamam de programas) para governar o comportamento" (Geertz, 1989).

Laraia (2002) ainda pondera que "uma compreensão exata do conceito de cultura significa a compreensão da própria natureza humana, tema perene da incansável reflexão humana". Nesse sentido, Feartherstone (1997) argumenta que a cultura adquiriu um papel extremamente significativo na vida social e que hoje, "tudo é cultural" nos termos de Baudrillard.

O conhecido Dicionário Aurélio faz referência a diversas noções de cultura e à sua origem etimológica em "cultivo". A propósito, convém recordar Delphim (2004), que refletiu em suas aulas sobre o homem "culto" nos termos da humildade, palavra derivada de húmus, no sentido de possuir interiormente um terreno fértil para o cultivo das idéias. Segundo o pesquisador de cultivo provém, através do alemão Kultur, o vocábulo cultura, ato ou efeito de cultivar. O Aurélio registra ainda a noção antropológica de cultura: "conjunto de características humanas que não são inatas, e que se criam e se preservam ou aprimoram através da comunicação e cooperação entre indivíduos em sociedade" (2004:587). Também traz à tona o uso corrente da palavra entendida como refinamento de hábitos, modos ou gostos, apuro, esmero, elegância, desenvolvimento intelectuais; saber, instrução e ilustração, referindo-se a pessoa esclarecida, "ser culto", sentido mais atribuído à noção pelo senso comum. De certa forma, o turismo reproduz esse senso comum, conferindo status de pessoa culta a quem muito viaja. Ao mesmo tempo, que o acesso ao "turismo de massa" cada vez mais está sendo disponibilizado às classes populares, por outro lado elitiza-se o acesso ao que comumente é entendido como turismo cultural e ecoturismo. Até mesmo o que se promove como "turismo cultural" passa por essa visão equivocada e distorcida de cultura.

Quando se instaura a fragmentação entre cultura e cultura popular e a idéia de cultura passa a confundir-se com "alta" cultura ou cultura "erudita", 
desloca-se o conceito da vida cotidiana, localizando-o em outros lugares, nos bancos das escolas, nos museus, nas viagens pelo mundo; locais de status que são instituídos socialmente. No entanto, são conceitos entranhados, que a divisão polariza e discrimina. Reproduz-se assim muito mais que o senso comum, reforça-se também um modelo de sociedade calcado na própria divisão de classe e de trabalho, separando os espaços de cada um, o do trabalho manual e do intelectual (Arantes, 2004).

Concernente, Cavalcanti (2001) contextualiza que a fala sobre folclore e cultura popular inaugura-se, quando se reconhece, intelectualmente, uma distância entre os modos de vida e saberes das elites e do povo. Acredita-se, no entanto, que no plano filosófico essa dicotomia está ultrapassada sendo "importante perceber que na atualidade o modelo interpretativo de duas camadas - cultura popular/folclore versus cultura de elite - está unanimemente superado", afirma Cavalcanti (2001:72).

Essa posição encontra eco em Arantes (2004), que traduz essa convivência indissociável entre a cultura dita de elite, refinada e os modos populares de vida.

"Refletindo (...) sobre essas diferenças, alguns valores e concepções são implementados socialmente, através de complexos mecanismos de produção e divulgação de idéias, como se fossem, ou devessem se tornar, os modos de agir e de pensar de todos (...) Embora nos ensinem a ter um modo de vida refinado, civilizado e eficiente - numa palavra, "culto"- não conseguimos evitar que muitos objetos e práticas que qualificamos de "populares" pontilhem nosso cotidiano." (Arantes, 2004:10-12)

$\mathrm{Na}$ verdade as práticas populares e cotidianas estão entranhadas na vida das pessoas, refletidas nas festas como o carnaval, o samba, as festas do boi, as festas juninas, entre outros costumes cotidianos. Segundo Arantes, "por mais contraditório que possa parecer, são exatamente esses objetos e modos de pensar considerados simplórios, rudimentares, desajeitados e deselegantes os que reproduzimos religiosamente em nossas comemorações nacionais" (2002:15). Para o pesquisador esse distanciamento resulta do paradoxo construído, sobretudo no capitalismo, para justificar as desigualdades sociais, demarcando diferenças entre o conhecimento intelectual carregado de valor e o 
conhecimento popular, desvalorizado. Dessa forma, um sistema complexo de idéias dominantes direciona o modo de aceitar e pensar o que está posto como natural.

\subsection{Patrimônio: uma nova concepção}

O dicionário Aurélio (2004) ao captar o entendimento mais comum da palavra patrimônio revela um pouco do sentido atribuído ao termo e mais incorporado às pessoas, desmistificando a idéia de um conceito abstrato e, portanto, de domínio de especialistas. Derivado do latim patrimonium, o termo significa herança paterna (pater), bens de família, dote, riqueza. Partindo dessa associação mais corriqueira, o dicionário registra patrimônio como bem, ou conjunto de bens culturais ou naturais, de valor reconhecido para determinada localidade, região, país, ou para a humanidade, e que, ao se tornar(em) protegido(s), p. ex., pelo tombamento, $\operatorname{deve}(\mathrm{m})$ ser preservado(s) para 0 usufruto de todos os cidadãos. O dicionário ainda cita Maria Cecília Londres Fonseca, em "O Patrimônio em Processo", (2001:58), expondo que "a idéia de posse coletiva como parte do exercício da cidadania inspirou a utilização do termo patrimônio para designar o conjunto de bens de valor cultural que passaram a ser propriedade da nação, ou seja, do conjunto de todos os cidadãos".

Os estudos da historiadora Fernanda Severo sobre o patrimônio atraem a atenção à palavra Monere, termo latino que é raiz comum das expressões patrimoniun e monumentum, significa "lembrar", ou "aquilo que traz à lembrança". Conforme Severo o trazer à lembrança é uma espécie de exercício de evocação de um passado que compartilhamos com os que nos precederam, representado por um edifício, uma rua, um artefato, uma imagem ou mesmo uma prática social cotidiana transmitida de geração para geração pela oralidade. "É exatamente nesse sentido que os espaços arquitetônicos considerados patrimônio histórico vinculam-se à noção de monumento, uma vez que nos impelem ao exercício de reconhecimento/pertencimento, resgatando de nossa memória símbolos, imagens e vivências individuais e sociais temporalmente delimitadas" (Severo). Essa mesma perspectiva é ampliada pela abordagem sustentável, que considera ainda àqueles que irão 
nos suceder, dentro de uma ótica de continuidade entre passado-presentefuturo. Nesse sentido, para a OMT (2003) turismo sustentável significa que os recursos naturais, históricos e culturais para o turismo sejam preservados para o uso contínuo no futuro, bem como no presente.

A primeira concepção de patrimônio adotada pela política pública no Brasil relaciona-se com a criação da Secretaria do Patrimônio Artístico Nacional - SPHAN em 1937, marcada pela restauração e conservação do patrimônio edificado (igrejas, museus, cidades históricas, sedes de governo) e de arquivos. A prática preservacionista, alcunhada de patrimônio "de Pedra e Cal", acabou por desmerecer em sua gênese a dimensão imaterial, priorizando os bens materiais, imóveis e móveis, considerados mais vulneráveis e ameaçados na época. Conforme Laraia (2004:12) parece que havia "um sentido pragmático (...) e de urgência decorrente da constatação traumática da iminência de seu desaparecimento". De acordo com Santos (2001) citado por Laraia (2004):

"Sempre terá parecido aos especialistas do patrimônio cultural..., que os bens imateriais tinham, nas próprias comunidades, defensores espontâneos e intransigentes, ao contrário dos bens materiais, tragicamente condenados à violência com que o Brasil da segunda metade do século $X X$ se devotou à destruição e descaracterização sistemática da paisagem urbana e da arquitetura tradicional". (Santos apud Laraia, 2004:13)

Segundo informações trazidas no estudo sobre patrimônio cultural: "Memória, Identidade e Referências Culturais sobre o Núcleo Pioneiro Goiano" realizado pelo Instituto Goiano de Pré-História e Antropologia da Universidade Católica de Goiás o segundo período importante vincula-se a Aloísio Magalhães, a partir daí amplia-se as políticas públicas para o patrimônio cultural, de forma a redimensionar o conceito, destacando não só o patrimônio edificado, mas também outras representações de igual legitimidade da nação brasileira, como seus costumes, modos de ofício, festas e celebrações. Introduzia-se então a noção de bens culturais, representativos da diversidade cultural do país (Gonçalves, 1996). Para esta pesquisa vamos ater-se a este segundo período onde a noção de patrimônio assume a dimensão do que hoje é conhecido como imaterial ou intangível. Apesar de reforçar uma falsa dicotomia, parece um mal necessário, pois é com essa distinção, que "delimita- 
se um conjunto de bens culturais que, apesar de estar intrinsecamente vinculado a uma cultura material, não tem sido reconhecido oficialmente como patrimônio nacional" (Dossiê GTPI, 2003).

Em visita ao Departamento do Patrimônio Imaterial na sede do Iphan, em Brasília, para uma entrevista com a diretora Márcia Sant'Anna encontra-se nas paredes um banner com a seguinte definição:

"Patrimônio é aquilo que nos deixaram nossos antepassados. Patrimônio é também aquilo que nos é próprio, nosso caráter, nossa maneira de ser. O patrimônio, portanto, não são somente as coisas que demonstram nossa eficiência nas artes e nas ciências, são as maneiras que temos de manifestar nossos afetos, nosso valor ou diferenças. São nossos costumes, nossas comidas, nossas festas, nossas danças, nossas histórias, nossas músicas, são os objetos de nossa vida diária, produzidos e usados com carinho."

O original do texto acima estava em espanhol, para isso, fez-se uma tradução com uso de dicionário, o que pode trazer alguma distorção, no entanto, o interesse maior foi reter aqui o enunciado que o próprio IPHAN, um dos principais expoentes do campo no Brasil, tem apresentado aos "outros", no caso, países de origem hispânica. Uma definição reveladora, acenando as dimensões amparadas pela nova noção de patrimônio, consagradas no Decreto $n^{\circ}$. 3.551 de 4 de agosto de 2000, que trata da proteção desses valores que constituem o patrimônio dito imaterial.

$\mathrm{Na}$ vanguarda das preocupações internacionais, de acordo com LéviStrauss (2001) o Brasil dotou-se de meios jurídicos, científicos e administrativos para melhor conhecer, valorizar e favorecer a permanência de uma porção substancial do patrimônio cultural nacional, de riqueza e diversidade excepcionais. Segundo Strauss, ao instituir os 4 primeiros livros de registro o decreto propôs:

"Uma solução inovadora do problema que parecia a priori insuperável, de integrar, num mesmo dispositivo, a prodigiosa diversidade e a infinidade de aspectos das inúmeras criações culturais reunidas na denominação genérica e cômoda, mas certamente simplificadora, de patrimônio imaterial". (Strauss, 2001:26)

A inscrição dos bens culturais no Brasil, portanto, é realizada em um dos quatro livros de registro, estabelecidos na proposta de instrumento legal, com 
base nas categorias identificadas na fase da pesquisa. O decreto presidencial assim estabelece:

Art. $1^{\circ}$ Fica instituído o registro de bens culturais de natureza imaterial que constituem patrimônio cultural brasileiro.

$\S 1^{\circ}$ Esse registro se fará em um dos seguintes livros:

I - Livro de Registro dos Saberes, onde serão inscritos conhecimentos e modos de fazer enraizados no cotidiano das comunidades;

II - Livro de Registro das Celebrações, onde serão inscritos rituais e festas que marcam a vivência coletiva do trabalho, da religiosidade, do entretenimento e de outras práticas da vida social;

III - Livro de Registro das Formas de Expressão, onde serão inscritas manifestações literárias, musicais, plásticas, cênicas e lúdicas;

IV - Livro de Registro dos Lugares, onde serão inscritos mercados, feiras, santuários, praças e demais espaços onde se concentram e reproduzem práticas culturais coletivas.

Recentemente, a Convenção para a Salvaguarda do Patrimônio Cultural Imaterial, aprovada pela Unesco em 17 de outubro de 2003, definiu por Patrimônio Cultural Imaterial:

"As práticas, representações, expressões, conhecimentos e técnicas - junto com os instrumentos, objetos, artefatos e lugares que Ihes são associados - que as comunidades, os grupos e, em alguns casos, os indivíduos reconhecem como parte integrante de seu patrimônio cultural. Este patrimônio cultural imaterial, que se transmite de geração em geração, é constantemente recriado pelas comunidades e grupos em função de seu ambiente, de sua interação com a natureza e de sua história, gerando um sentimento de identidade e continuidade, contribuindo assim para promover o respeito à diversidade cultural e à criatividade humana".

Em seus estudos de mestrado na Universidade de Brasília sobre as políticas públicas de patrimônio cultural, Garcia (2004) observou que foi a partir da relação entre o conceito antropológico de cultura e as políticas culturais, que o campo semântico da cultura começa a ter conexões com o patrimônio. "Parece que assistimos os dois, à medida que "cultura", em suas mais diversas acepções passa a ser tratada como um produto a ser consumido em todos os sentidos e, por isso, dialeticamente, deve ser também preservada." Para esta análise, Garcia (2004) recorre ao enunciado de Londres: 
"Patrimônio é tudo que criamos, valorizamos e queremos preservar: são os monumentos e obras de arte, e também as festas, as músicas e danças, os folguedos e as comidas, os saberes, os fazeres e falares. Tudo enfim que produzimos com as mãos, as idéias e a fantasia." (Cecília Londres, 2004:21).

De acordo com a interpretação da reflexão de Londres, essa ampliação da noção de patrimônio cultural só foi possível mesmo a partir dessa aproximação, iniciada nos anos 70, no Brasil, entre a antropologia e as políticas culturais, sobretudo nas áreas de patrimônio. Neste âmbito, Londres (2002) cita Fonseca (1997) e mostra sua compreensão de cultura popular por meio de Cavalcanti (2001).

A mesma discussão ressoa em teóricos contemporâneos Durham (1977), Yúdice (2002) e Arantes (2004), de forma ainda mais abrangente.

"Surge, assim, entre a cultura (como sistema simbólico reconstituído) e os símbolos articulados em atividades concretas, a mediação do entrejogo de interesses políticos divergentes de segmentos sociais que frequentemente, nas sociedades complexas, possuem acesso diferenciado aos meios e recursos necessários à sua expressão. Este é o contexto teórico mais global no qual se pode pensar adequadamente a cultura como produto". (Arantes, 2004).

Faz-se aqui uma ressalva em forma de pergunta: Produto ou Recurso? Em que os planejadores e gestores de políticas públicas estão transformando a Cultura? Talvez, a questão mereça mais atenção de estudos futuros.

Marisa Veloso (2004:31) contextualiza que patrimônio cultural imaterial deve ser entendido "como o repertório das expressões culturais de um grupo social, aqui incluídos os seus acervos históricos, em permanente e inexorável dinâmica(...) que definem e estruturam sua identidade". A pesquisadora reforça que idéia de patrimônio imaterial não só permitiu uma ampliação da noção de patrimônio, como também "permitiu abandonar falsas dicotomias e falsos pressupostos" (Veloso, 2004:31). Veloso nota que a discussão sobre patrimônio imaterial permitiu a depuração da noção de referência cultural, lapidado na formulação de Antônio Augusto Arantes, o qual considera identidade e territorialidade dois requisitos fundamentais para tal definição:

"Referência é um termo que sugere remissão: ele designa a realidade em relação à qual se identifica, baliza ou esclarece algo. No caso do processo cultural, referências são práticas e os objetos por meio dos quais os grupos representam, realimentam e 
modificam a sua identidade e localizam a sua territorialidade. São referências os marcos e monumentos edificados ou natural, assim como as artes, os ofícios, as festas e os lugares a que a vida social atribui reiteradamente sentido diferenciado e especial: são aqueles considerados os mais belos, os mais lembrados, os mais queridos, os mais executados". (Arantes, 2001:130-131)

Assim, ainda destaca Veloso:

"Importa ressaltar é que o conceito de referência cultural, que é um dos pilares da concepção de patrimônio-imaterial, remete-nos a significados compartilhados, onde a convivência é pautada por um universo de valores comuns" (2004:32).

A definição mesma do que se entende por patrimônio imaterial é motor de diversas reflexões entre os pesquisadores do tema, muitas perguntas ainda sem respostas têm fomentado a discussão filosófica em construção de um conceito, portanto, inacabado.

Inúmeras são as ramificações referentes a essa dimensão do patrimônio, que no Brasil foi nomeada e legitimada pela Constituição Federal, como patrimônio imaterial. Na carta de exposição de motivos direcionada ao então Presidente da República Fernando Henrique Cardoso, o Ministro da Cultura, Francisco Weffort relata que a inclusão de bens culturais referentes aos diferentes grupos formadores da sociedade brasileira no rol do nosso patrimônio cultural constitui uma demanda histórica que foi reconhecida pela Constituição Federal de 1988 em seu Artigo 216. O texto constitucional reconheceu a dupla natureza material e imaterial e estabeleceu, além do tombamento, o registro e o inventário como outras formas de acautelamento e proteção desses bens.

É possível perceber ainda, que devido à abrangência do termo e a toda complexidade do objeto que pretende definir, distorções sobre a terminologia têm sido freqüentes. Mesmo havendo divergências entre os autores, todos concordam com a importância atual da proteção desses aspectos do patrimônio, que não eram reconhecidos oficialmente até então.

Londres (2001:189) lança questões que revelam essa preocupação, quando examina se a expressão, Patrimônio Imaterial, não constituiria contradição em termos? Outras reflexões emergem nos estudos sobre Patrimônio Imaterial, como por exemplo, se o conceito não se confunde com o 
de Cultura Popular/Folclore. A mesma inquietação é latente em Marina de Mello Souza quando faz a seguinte digressão:

"Pessoalmente, acho a expressão bastante problemática. Por que imaterial, se esse patrimônio contém expressões do que os antropólogos chamam de cultura material, como as máscaras de Cazumbá, adereços do bumba-meu-boi...? Nesse conjunto de manifestações, cabem aquelas realizadas pelas classes dominantes, ligadas à chamada cultura erudita, ou apenas as produzidas pelas camadas populares? Cabem as invenções contemporâneas, o rap, o artesanato de material industrial reciclado, o resultado de intervenções eruditas junto a grupos populares, ou apenas aquilo que se liga a tradições reconhecidas enquanto tal, seja pela longevidade, seja pela sólida aceitação dentro do grupo que a realiza? Não sei se por causa do viés da minha formação, mas no meu entender, o que hoje se chama de patrimônio imaterial é o que a vinte anos chamávamos de cultura popular" (Souza, 2001:142).

O dossiê da Comissão e Grupo de Trabalho Patrimônio Imaterial, por sua vez, retrata bem essa complexidade do termo de acordo com a análise seguinte:

"Várias expressões, todas igualmente problemáticas e simplificadoras do ponto de vista conceitual, tem sido utilizadas, sendo as mais consagradas "patrimônio intangível", "patrimônio imaterial", "cultura tradicional e popular" e, mais recentemente, "patrimônio oral". As duas primeiras procuram delimitar esse universo por meio de uma categoria de patrimônio oposta ao chamado "patrimônio material ou construído" (Dossiê, 2000: 1213)

O documento ainda diferencia as nuances que prevalecem em cada uma dessas expressões mostrando que os qualificativos "imaterial" ou "intangível" pretendem ressaltar a importância dos processos de criação e manutenção do conhecimento sobre o seu produto (festa, a dança, a peça de cerâmica, por exemplo). Nesse caso, a ênfase recai no conhecimento e no processo de criação mais do que no resultado, "embora este seja sua expressão indubitavelmente material. A principal crítica a essas expressões é que estas levam a desconsiderar o resultado das manifestações e suas condições materiais de existência" (Dossiê, 2000:13). Por sua vez, a expressão "patrimônio oral", decorre de raciocínio semelhante, mas a ênfase prevalece no modo de transmissão dessas manifestações culturais. 
"Constitui uma tentativa, não muito bem sucedida, de superar os problemas conceituais contidos nas expressões "imateriais" e "intangíveis", bem como os reducionismos aos quais os adjetivos popular e tradicional podem conduzir. De fato, a expressão "cultura popular e tradicional" possibilita interpretação que tende a excluir expressões contemporâneas ou circunscrever esse universo às manifestações de determinada classe ou camada social. Em outras palavras, ela pode conduzir a um entendimento restrito sobre esse patrimônio, vinculando-se a critérios rígidos de temporalidade, classe e autenticidade". (Dossiê, 2000:13)

As respostas exigem um debruçar e um olhar profundo em cima dessas questões, mas sinalizam que patrimônio imaterial compreende também a cultura dita popular, sendo uma das dimensões do processo cultural (que se refere aos saberes e fazeres culturais, interiorizados e guardados na alma das pessoas e dos lugares), no entanto, não se limita apenas a essas manifestações culturais. Quando essa dimensão ocupa a centralidade das discussões filosóficas e de políticas públicas culturais, amplia-se, portanto, o olhar sobre a noção de patrimônio. É como se um segredo fosse revelado. A imaterialidade sempre esteve entranhada nas expressões culturais, mesmo nos monumentos de "pedra e cal", implantada nos usos e relações das pessoas junto ao patrimônio dito material, a partir desse redimensionamento da noção de patrimônio, estende-se, portanto, o alcance do que é patrimônio entendido como patrimônio material, como bem define Lévi-Strauss (2001):

"Patrimônio material e patrimônio imaterial não aparecem mais como duas áreas separadas, mas como um conjunto único e coerente de manifestações múltiplas, complexas e profundamente interdependentes dos inúmeros componentes da cultura de um grupo social" (Strauss, 2001:24).

Nesse sentido, Jérôme Monnet (1996) em seu artigo intitulado: "O álibe do patrimônio", extremamente crítico e de tom um pouco pessimista, adverte que as intervenções nos centros das cidades e bairros antigos sob a égide de proteção ao patrimônio podem tender a apropriações exclusivas em detrimento de sua historicidade e dos usos e práticas. Na prática urbanística moderna, essas áreas, normalmente, concentram conflitos de interesses entre produtores culturais, comerciantes, turistas, habitantes, poderes públicos, defensores do patrimônio, planejadores de locais turísticos e peritos científicos. É o caso do Pelourinho, na capital da Bahia, que deixou seus usos (moradia, historicidade, 
comércio, passeio) para transformar-se em um espaço temático para turistas, onde as pessoas que ali pertenciam não se reconhecem mais. Essa análise realizada pelo pesquisador da USP, Paulo Marins, foi apresentada durante uma aula-convite para a $1^{\mathrm{a}}$. Turma do curso de pós-graduação em Turismo: Cultura e Lazer, da UnB. Marins fez um diagnóstico crítico sobre o Pelourinho. "O espaço social e a memória foram evaporados do lugar, uma situação fraudulenta do ponto de vista do gerenciamento e planejamento urbano, uma aberração, já que está direcionado só para o turista e depende só desse fluxo", disse o pesquisador.

Para Monnet (1996) a dimensão essencial desses espaços é justamente ser vivido como espaço de confronto, de contato, de mistura, o que as estratégias de proteção patrimonial, por vezes, acabam por deslocar o uso e as práticas do lugar transformando-o em um "não-lugar", nos termos de Marc Augé. Essa preocupação de alguns teóricos, evidentemente, acabou sendo mais refletida do ponto de vista dos patrimônios materiais, por sua predominância nas políticas de proteção cultural. Mas a mesma preocupação existe quanto aos bens imateriais nos desdobramentos futuros e na própria evolução da política cultural acerca do patrimônio cultural brasileiro, enfim no que será construído do resultado dessas políticas. Proteção, conservação, descaracterização, recurso turístico ou mercadoria turística, espetáculo.

Acredita-se que a qualificação do turismo não depende simplesmente de um entendimento isolado sobre determinados aspectos, principalmente se sustentado em bases de crescimento econômico, sem considerar todo o sistema complexo que envolve o processo de "turistificação", levando em conta o lugar, o que implica principalmente as pessoas que compõem o lugar. Em seus estudos de mestrado Zerbini (2005) mostra que para se ter uma compreensão plena da realidade urbana "não se pode ter uma visão monoprismática e objetiva do espaço, mas sim tentar perceber os múltiplos jogos de valores que se dão na interdependência entre o homem e seu meio", afinal "um indivíduo não é distinto do lugar: ele é o lugar" (Zerbini cita Marcel,

\footnotetext{
${ }^{3}$ Segundo BARROS, (2002:36) turistificação de espaços é o processo de mudanças precipitado sobre um dado lugar visando adequá-lo a tornar-se um espaço de atividade turística. LIMA e CANDEIAS (2000) recorrem ao mesmo conceito citando KNAFOU (1996) mostrando que as incidências do turismo nas esferas da organização sócio-espacial articulam ações que denotam a totalidade do espaço turístico ou a "turistificação".
} 
2000:22). Desse ponto de vista, o turista pode ser considerado uma espécie de morador temporário, fazendo parte do lugar momentaneamente.

Dessa forma, os estudos de Zerbini relativos à arquitetura podem também colaborar com projetos para o turismo, no sentido que a autora defende que o ideal seriam projetos de interfaces e de coexistência entre usuário, comunidade e profissional. A presente pesquisa também pondera a coexistência e interface entre essa triangulação (usuário-comunidadeprofissional) nos projetos turísticos, especialmente em projetos de interface entre proteção cultural e turismo que considere um olhar interdisciplinar. Ressalta-se assim, a necessidade de coexistência entre a comunidade, o profissional do turismo (turismólogo, empreendedor, instituições públicas de turismo e cultura, produtor cultural etc.) e o turista, permitindo uma qualificação de todo o processo, com satisfação tanto do usuário (no caso, o turista), quanto do lugar (como espaço e pessoas) e do profissional.

A esse respeito, Mendonça (2004) aponta que os planos oficiais para o incremento da atividade turística no Brasil tem considerado o desenvolvimento do turismo sustentado em duas de suas principais vertentes - o ecoturismo e o turismo cultural - como facilitadores do aumento da afluência de turista estrangeiros ao País. Ao mesmo tempo em que o turismo cultural tem sido detectado como potencial turístico inigualável para o Brasil, devido à diversidade cultural peculiar e especial do país, assunto este presente nos discursos oficiais sobre a potencialidade turística brasileira, o turismo cultural tem se desenvolvido à revelia da proteção desses bens culturais $\mathrm{e}$ manifestações. Transformados rapidamente em "produto turístico" acabam não fazendo parte de um planejamento cuidadoso que regule essa relação, principalmente no que diz respeito à proteção cultural, aspecto que deveria ocupar a centralidade e atenção do desenvolvimento das políticas públicas do turismo cultural. Nesse sentido, afirma Mendonça:

"A ausência de políticas culturais claras para o turismo no que se refere à concepção mesma de cultura (cultura como patrimônio, como folclore, coleção de objetos ou como vivência) torna as diferentes manifestações culturais rapidamente transformadas em mercadorias "turísticas". Qualquer possibilidade de alteração dessa tendência dominante deverá passar por uma nova visão não só da necessidade de um planejamento sustentável, mas por 
uma reeducação dos indivíduos no sentido de poder transformar o turista em viajante." (Mendonça, 2004)

Essa perspectiva sugere um exercício de mudança de paradigmas na própria concepção dos projetos turísticos que tendem prioritariamente a atender o turista e os interesses dos grandes investidores, deixando de lado questões importantes como a comunidade e suas particularidades culturais locais, a sustentabilidade do destino e do atrativo turístico, que neste caso, compreende os atrativos culturais. Essa reeducação do turista em viajante (que se desloca com intuito de conhecer o outro), passa pela qualificação dos projetos com concepções mais amplas que leve em conta a cidadania da comunidade envolvida no processo de turistificação, a preservação natural e cultural, a informação qualificada capaz de instruir o turista nesta viagem de conhecimento e sem dúvida projetos que considere essa triangulação entre usuário (turista), comunidade (local), profissional (incluindo empresários e projetistas), ou seja, mais do que transformar a cultura em apenas novos produtos mas como forma de valorizá-la e respeitá-la em seu contexto local.

Para isso, o próximo capítulo traz uma análise do Plano Nacional do Turismo, PNT, e da sua interface com o Programa Nacional do Patrimônio Imaterial, PNPI, políticas em vigência no atual governo. Observa-se como se dá a relação entre Patrimônio Imaterial e Turismo, por meio do PNT, principal instrumento voltado à organização e ao desenvolvimento do setor do turismo no Brasil. Procura-se identificar como esse aspecto cultural, o patrimônio imaterial, está sendo tratado na nova política pública de turismo, já que as festas, a culinária, o artesanato e as manifestações culturais têm sido apresentados como uma das principais potencialidades turísticas do Brasil, fazendo parte do então turismo cultural, entendido como influenciador no aumento da afluência de turista, principalmente do turista estrangeiro. O próprio Ministério do Turismo define Turismo Cultural ${ }^{4}$ como "atividades turísticas relacionadas à vivencia do conjunto de elementos significativos do patrimônio histórico e cultural e dos eventos culturais, valorizando e promovendo os bens materiais e imateriais da cultura". Percebe-se que conceitualmente o MTur já

4 Este conceito é resultado das discussões do Grupo de Trabalho de Turismo Cultural, organizado pela Secretaria Nacional de Políticas de Turismo, do qual fazem parte diversas instituições governamentais e privadas, com representação no Conselho Nacional de Turismo. 
considera a vivência turística dos aspectos culturais, carregando uma idéia de experiência turística e a questão da valorização e promoção dos bens culturais, já abarcando os aspectos imateriais. Portanto, pelo menos no conceito a interface entre Turismo e Cultura parece estar contemplada, o detalhamento de como essa relação está se dando no desenvolvimento das políticas públicas será verificado na análise apresentada no capítulo seguinte. 


\section{Análise do Plano Nacional de Turismo e do Programa Nacional do Patrimônio Imaterial}

Neste capítulo são apresentados os objetos de estudo desta pesquisa: o Plano Nacional de Turismo (PNT: 2003-2007) e o Programa Nacional do Patrimônio Imaterial (PNPI), seus principais objetivos, linhas de ação e diretrizes. Primeiramente, mostra-se o teor de políticas desenvolvidas com o propósito de preservação do patrimônio imaterial, no caso, o PNTI, verificando se essa ação está sendo aplicada e integrada ao desenvolvimento da atual Política Nacional de Turismo. Tal investigação procurou identificar na prática o que vem sendo apresentado nos discursos oficiais do governo federal: "a cultura como produto turístico". A palavra foi grifada por esta pesquisa ponderar o entendimento da "cultura como recurso" para o turismo, parafraseando o título e o pensamento da obra de Yúdice (2002) "EL Recurso de La Cultura: usos de la cultura em la era global", o que será abordado mais adiante.

Objetiva-se ainda promover a discussão sobre a interface entre essas políticas e seus respectivos órgãos, MTur e Iphan/MinC, levando em conta a pergunta norteadora: Patrimônio imaterial e turismo, questões incompatíveis?

Essa etapa da pesquisa centrou-se no seguinte problema: Como se dá a relação entre patrimônio imaterial e o desenvolvimento do turismo, no âmbito do governo federal?

\subsection{O Plano Nacional do Turismo (PNT: 2003-2007)}

O Plano Nacional do Turismo é o principal instrumento de planejamento do Ministério do Turismo, lançado no dia 29 de Abril de 2003, três meses depois da criação do Ministério do Turismo. Tem por finalidade expor o pensamento do governo e orientar as ações necessárias ao desenvolvimento do turismo. As bases retóricas que moldam suas principais argumentações circundam acerca do seu papel articulador, dentro de um novo modelo de 
gestão pública descentralizada e participativa, atingindo em última instância o município, focando a geração de emprego, renda, divisas e redução das desigualdades sociais. Isso é bem documentado na missão do MTur: "Desenvolver o turismo como uma atividade econômica sustentável com papel relevante na geração de empregos, divisas, proporcionando a inclusão social". Nota-se que há um enfoque econômico, mesmo que se refira a atividade econômica sustentável, é a abordagem econômica que está sendo privilegiada. $\mathrm{O}$ que pode ser mais bem verificado nas 5 metas estabelecidas no PNT para o turismo.

\section{METAS PARA O TURISMO - 2003 - 2007}

$\checkmark$ Criar condições para gerar 1.200 .000 novos empregos e ocupações

$\checkmark$ Aumentar para 9 milhões o número de turistas estrangeiros no Brasil

$\checkmark$ Gerar 8 bilhões de dólares em divisas

$\checkmark$ Aumentar para 65 milhões a chegada de passageiros nos vôos domésticos

$\checkmark$ Ampliar a oferta turística brasileira, desenvolvendo no mínimo três produtos de qualidade em cada Estado da Federação e Distrito Federal.

Para o pesquisador João dos Santos Filho (2003) estas metas só serão realidade se o país investir de forma maciça no turismo, não o entendendo mais como um item secundário e complementar ao planejamento do Estado. Nesse contexto, a diretora do Departamento de Patrimônio Imaterial do Iphan, Márcia Sant'Anna (entrevista 1:2005), levanta algumas ressalvas e cautelas à abordagem "salvacionista" anunciada nos discursos do desenvolvimento do turismo, para ela a atividade é secundária no sentido de depender de uma base social e econômica bem estruturadas para se desenvolver, enfrentando, portanto, problemas estruturais no Brasil.

Uma das principais críticas de Santos Filho (2003) ao PNT é que as políticas públicas precisam ser pensadas para o povo brasileiro e não para o estrangeiro, sendo que o PNT não privilegiou o que no jargão técnico é chamado de turismo doméstico. Segundo ele, a prioridade deve ser o turismo interno o que pode alavancar o fluxo internacional para o Brasil, "o fluxo turístico nacional é que deve dar as bases e implementar o desenvolvimento do 
turismo no Brasil, e não ao contrário, portanto, vender a imagem do país para o exterior, deve ser uma etapa que esteja abaixo do patamar do turismo nacional" (Filho, 2003). O pesquisador explica ainda que para atingir a meta dos 9 milhões de estrangeiros, "o receptivo nacional teria de ser 50\% do fluxo de estrangeiros que vão à América Latina" (Filho, 2003). Nesse sentido, a integração com a vizinhança latino-americana tem sido pouco explorada pelas políticas públicas brasileiras, o que poderia fortalecer o turismo interno latinoamericano, gerando parcerias e ampliando a recepção e emissão de turistas dentro da própria América Latina, como o é, na Europa, onde um país emite fluxo para o outro, fortalecendo o turismo europeu como um todo.

Sant'Anna, por exemplo, observa que um "equívoco básico permanece nas políticas de turismo brasileiro desde os anos 70 , o desenvolvimento concentrado na produção de destinos turísticos e de produtos turísticos e muito menos na recepção do turista e na inserção dele na vida do lugar". Segundo ela, ao contrário do pensamento moderno de desenvolvimento do turismo no mundo, mantém-se no Brasil o enfoque na "construção de grandes empreendimentos turísticos e de grandes resorts, desvinculados da realidade do lugar onde se está visitando, sendo que o turista contemporâneo quer participar da vida daquele lugar no que tem de próprio e típico" (Entrevista 1:2005).

A diretora do DPI comenta que essa concepção de turismo massificada cria lugares turísticos, que acabam sendo não-lugares, conforme Marc Augé (1994), sem vida e sem personalidade. Uma tendência internacional, pelo menos no discurso é "preparar os lugares para si próprios, para sua população, para o seu cotidiano de modo que tenham capacidade de receber o visitante sem que este precise estar numa redoma", relata Sant'Anna (Entrevista 1:2005). Infelizmente, o turismo brasileiro ainda tem preparado as cidades e os lugares para o: Turista, o que "de certa forma é falso, desassociado da realidade do local, acabando por gerar conflitos e expor o turista a todo o problema social que está em volta" (Entrevista 1:2005). Esse pensamento redimensiona o desenvolvimento do turismo a partir da comunidade local, no sentido de que o lugar será bom para o turismo se for bom para as pessoas e para o lugar onde o turismo acontece. 
3.2. O papel de articulação do MTur e a gestão descentralizada

No Plano Nacional de Turismo o papel de articulador do Ministério do Turismo é sancionado como "órgão da administração direta, que terá as condições necessárias para interagir com os demais ministérios, com os governos estaduais e municipais, com o Poder Legislativo, com o setor empresarial e a sociedade organizada, integrando as políticas públicas e o setor privado". Nesse contexto, os pesquisadores Sansolo e Cruz lançam uma preocupação: "as interfaces entre turismo e outras práticas sociais e produtivas são fortes e evidentes e daí a problemática da concentração de ações voltadas ao seu desenvolvimento em um único órgão da administração" (2003). Isso sugere uma integração muito bem estruturada entre os agentes públicos e privados, além do terceiro setor e a comunidade propriamente dita, parte integrante do lugar, "atingindo em última instância o município, onde efetivamente o turismo acontece", é assim que o plano identifica seu principal desafio de "conceber um novo modelo de gestão pública.... para solidificar uma estrutura turística integrada e duradoura, baseado na força das Parcerias e na Gestão Descentralizada", (PNT, 2003:10, negrito do documento).

A política nacional de turismo tem esboçado essa descentralização na configuração do Conselho Nacional de Turismo - CNT, no sistema de gestão do Ministério do Turismo, configurado mais tarde no Modelo da Superestrutura, como pode ser verificado por meio da figura 1, abaixo, e pelo que dispõe o trecho seguinte: "O Ministério do Turismo tem como desafio implementar um modelo de gestão pública descentralizada e participativa, estabelecendo canais de interlocução com as Unidades da Federação, a iniciativa privada e o terceiro setor. Esse novo modelo é composto por um Núcleo Estratégico, formado pelo Ministério do Turismo, através do Conselho Nacional de Turismo e as Câmaras Temáticas, o Fórum Nacional de Secretários e Dirigentes Estaduais de Turismo e os Fóruns / Conselho Estaduais de Turismo" (Documento do CNT sobre as Câmaras Temáticas, 2004). 


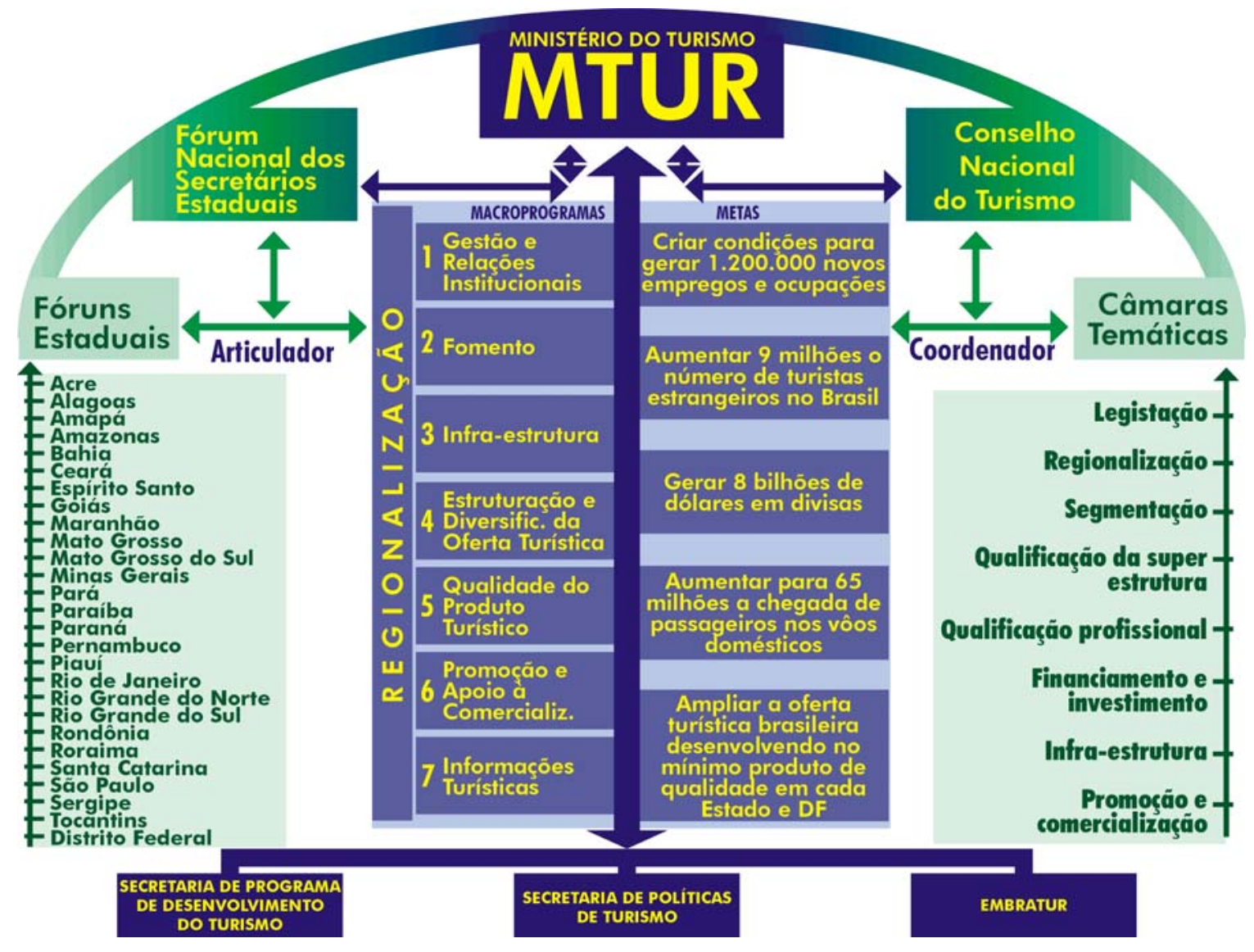

Figura 1: Modelo da Superestrutura, definido pelo Departamento de Planejamento e Avaliação do Turismo - DPAT/MTur - Agosto de 2004.

Nessa configuração, o Conselho Nacional de Turismo é um órgão colegiado de assessoramento à formulação e aplicação da Política Nacional de Turismo e dos respectivos Planos, Programas, Projetos e atividades dela derivados, vinculado à estrutura do MTur. Atualmente, composto por mais de 60 entidades, divididas entre públicas, privadas e representantes da sociedade civil organizada, com representação nacional. Presidido pelo Ministro de Estado do Turismo, Walfrido Mares Guia, o conselho reúne-se trimestralmente, nos meses de março, junho, setembro e dezembro, somando até o momento oito reuniões realizadas, no período de abril/2003 a junho/2005. Nessa configuração, a presença das comunidades e associações locais são mais possíveis na esfera dos Fóruns/Conselhos Estaduais, caso participem de uma entidade com representação estadual, ou nas próprias instâncias regionais e municipais onde estão inseridas, isto é, se se constituírem em sociedade civil organizada. 
Quando se analisa a participação do terceiro setor no documento sobre a "Composição do Conselho Nacional de Turismo - CNT", como pode ser verificado no anexo $\mathrm{C}$, as instituições representativas deste segmento, a ABONG - Associação Brasileira de Organizações Não Governamentais e o Fórum Brasileiro de Organizações Não Governamentais, que são considerados membros efetivos do Conselho Nacional do Turismo não efetivaram essa participação. Como o CNT serve de modelo base para a composição dos demais Conselhos/Fóruns nos níveis estadual, regional e municipal, percebese assim uma participação pouco expressiva do terceiro setor em toda a cadeia de descentralização. Segundo entrevista com a Coordenadora do CNT, Marta Feitosa (Entrevista 2:2005), ambas as entidades foram convidadas com insistência, entretanto nunca indicaram representantes e acabaram sendo excluídas do Conselho devido a essa não indicação. Assumindo uma postura mais distanciada, de tal modo, mais livre à crítica, acabam por omitir a força do terceiro setor na arena de interesses divergentes que formata o CNT, deixando de contribuir neste contexto com a mudança do que criticam como "turismo clássico" ou "predatório". O Grupo de Trabalho, GT Turismo Sustentável, criado no Fórum Brasileiro de Organizações Não Governamentais de 2004, comenta que o crescimento da demanda internacional de 100\% em 4 anos, previsto no Plano Nacional de Turismo causará inúmeros conflitos sócio-ambientais. Para isso, sugerem para os rumos do GT de Turismo Sustentável a aproximação com os Conselhos Titulares nas próprias cidades turísticas.

Outro problema é que nem sempre o terceiro setor representa os reais interesses das comunidades e dos grupos sociais não organizados que se encontram na linha de ponta do acontecimento turístico, recebendo o fenômeno gerado pela então política de desenvolvimento do setor. Como fazer para garantir e ampliar a participação da comunidade no centro das decisões e do planejamento governamental participativo e descentralizado, sendo que na própria missão do MTur fala-se de inclusão social?

Portanto, o desencadeamento da gestão descentralizada perpassa várias fases e choca-se com conflitos de interesses, inclusive internamente envolvendo os próprios órgãos do governo federal, quando não os próprios departamentos e instituições de um mesmo órgão; e externamente nas esferas estaduais e municipais. Esse novo pensamento estratégico moldado na 
descentralização ainda é um exercício novo na gestão pública, talvez mais do que isso, um exercício novo para cada indivíduo que compõe essa gestão, um exercício da democracia "utópica", contrário aos estímulos do individualismo e dos egos que ouriçam a disputa. Isto nos faz remeter à discussão travada por Bourdieu sobre "disputa de campos" já tratada anteriormente, percebe-se que a descentralização ainda está mais no discurso, não sendo balanceada entre a composição tripartite (setor público-setor privado-terceiro setor). Intrigante essa contradição entre o discurso e a prática, que acaba mostrando que o terceiro setor e a comunidade possuem uma representação pouco expressiva dentro dos espaços onde teriam legitimação dentro da nova política nacional de turismo, emergindo aqui, mais um ponto para estudos futuros. O que explica essa representação enfraquecida do terceiro setor e, portanto, da sociedade, por um lado a falta de se constituírem em sociedade civil organizada mas por outro lado a não tão descentralizada política pública, prevalecendo os interesses do setor público e privado.

Ë claro, que se existem dificuldades de integração e flexibilização dentro de um mesmo órgão com interesses comuns, não há como esperar que não seja difícil essa articulação entre setores com interesses tão diversos. É conhecido, exemplos, de órgãos públicos que internamente disputam entre si, não articulando de forma integrada as suas próprias ações entre os departamentos, as secretarias, os institutos e demais membros da estrutura interna. Esse enfoque exige, assim, mudança de paradigmas arraigados na administração pública e nas entranhas dos egos inflados, exigindo um aperfeiçoamento interior. Saber ouvir os diferentes pontos de vista dos envolvidos no processo turístico e administrar esses interesses divergentes contemplando principalmente a tão almejada sustentabilidade. É um desfio permanente, que nem sempre agradará a todos, mas certamente norteará um desenvolvimento cuidadoso, responsável e contínuo.

De acordo com documento do MTur que define as atribuições do Fórum Estadual, este é "uma entidade de caráter propositivo, consultivo e mobilizador, que visa a integração de todas as instituições que compõem a cadeia produtiva do turismo, em cada Unidade da Federação" (MTur, 2004), sendo sua composição tripartite - Governo, Iniciativa Privada e Terceiro Setor. Desde o final de 2003, os 27 Fóruns/Conselhos estão todos constituídos e são 
responsáveis por ampliar a gestão descentralizada e participativa na esfera estadual. "Principal instrumento no processo de descentralização da atividade turística no País, funciona como um canal entre o Núcleo Estratégico de Turismo - Ministério, Conselho Nacional de Turismo e Fórum Nacional de Secretários e Dirigentes de Turismo - e o Estado, as Regiões e os Municípios", define o documento.

Considera-se, portanto, que esse repasse de uma nova concepção de planejamento e gestão compartilhada do turismo não é simples nem automático, enfrentando entraves e dilemas desde o modelo base, no caso 0 Conselho Nacional de Turismo (nível federal), passando pelos Fóruns/Conselhos Estaduais (nível estadual) até chegar à organização de todo o setor nas regiões turísticas e no próprio município (nível municipal).

\subsection{O Programa Nacional do Patrimônio Imaterial - PNPI}

A íntegra do Programa Nacional do Patrimônio Imaterial (PNPI) encontra-se ao final deste trabalho como anexo D. O PNPI, instituído pelo Decreto $\mathrm{n}^{\circ}$ 3.551, de 4 de agosto de 2000, é um instrumento de gestão da política pública de registro dos bens culturais de natureza imaterial, sua principal atribuição é a viabilização de projetos de identificação, reconhecimento, salvaguarda e promoção da dimensão imaterial do patrimônio cultural. É um programa de fomento que busca estabelecer parcerias com instituições dos governos federal, estadual e municipal, universidades, organizações não-governamentais, agências de desenvolvimento e organizações privadas ligadas à cultura, à pesquisa e ao financiamento. O grifo teve o intuito de chamar a atenção à importância dada às parcerias entre os diversos atores sociais citados, mas principalmente a própria esfera do governo federal, que no contexto desta pesquisa, envolvem dois destes órgãos, o Ministério do Turismo e o Ministério da Cultura/Iphan, peças de um mesmo dominó. ${ }^{5}$

\footnotetext{
${ }^{5}$ Aqui a palavra dominó remete aos prédios da Esplanada dos Ministérios (onde estão o MinC e o MTur, em Brasília) a alusão figurativa de um jogo de dominó com as peças emparelhadas, já assim assimiladas pelo meu sobrinho Ricardo, de 10 anos, na primeira vez que viu a Esplanada e recentemente desenhados como um jogo de dominó por Ziraldo, um dos maiores chargistas brasileiro, famoso por captar o universo infantil.
} 
Entre os quatro objetivos apresentados, um dos principais é a própria implementação da política de inventário, registro e salvaguarda de bens culturais de natureza imaterial, de forma a contribuir para a preservação da diversidade étnica e cultural e disseminar informações sobre o patrimônio cultural brasileiro a todos os segmentos da sociedade. Outro objetivo é a captação de recursos e formação de uma rede de parceiros com vistas à preservação, valorização e ampliação dos bens que compõem o patrimônio brasileiro. Por fim, incentivar e apoiar iniciativas e práticas de preservação desenvolvidas pela sociedade. Entre os objetivos expostos, mais uma vez, ressalta-se a rede de parceiros, dentro dessa perspectiva, a política nacional de turismo pode vir a contribuir com a promoção dos bens culturais imateriais, disseminando informações, bem como, na sua preservação, valorização e salvaguarda, desenvolvendo práticas e iniciativas, inclusive de forma a somar recursos. No entanto, o documento não aponta como será a construção dessa rede ampla de parceiros, parecendo mais um indicativo de necessidade do que de desenvolvimento de um planejamento integrado e efetivo.

Quem são os parceiros potenciais, principalmente, na esfera do próprio governo federal? Que instrumentos estão sendo elaborados para regular essa relação e promover as interfaces? Qual o papel de cada um, dentro de um planejamento participativo e descentralizado? Lança-se as perguntas ao meio da trama para provocar quem sabe o tecer de uma política compartilhada, insinuada nos objetivos elencados pelo próprio programa. A apropriação dos bens culturais pelo turismo precisa ser motivo de discussões integradas e reflexões profundas, no intuito, de estabelecer conceitos, normas, recomendações e instruções éticas e sustentáveis para regular essa relação, levando em conta a participação da comunidade, principalmente dos detentores desses bens culturais, pois é lá que desemboca toda a experiência turística.

As intervenções turísticas em relação ao patrimônio material têm sido motivo de discussões patrimoniais e de recomendações documentadas em manuais, ou mesmo de desenvolvimento de programas do governo em parcerias com entidades privadas, como é o caso do Programa Monumenta, uma parceria do Ministério da Cultura com o BID. Mesmo assim, ainda se vê exemplos de descaracterização e equívocos, às vezes, modificando a própria 
essência de um local historicamente constituído, eliminado sua gente e as práticas culturais ali enraizadas, tecidas pelas relações de geração em geração. Portanto, não há dúvida, que essa relação entre turismo e cultura, principalmente no que diz respeito ao patrimônio cultural brasileiro, quer material ou imaterial, precisa ser regulada, sendo esse talvez o maior desafio do Governo Federal, o de promover as interfaces interdisciplinares e dos diversos setores, formando mesmo uma grande rede de parceiros, para fazer do turismo uma ferramenta de desenvolvimento responsável do país dentro de uma perspectiva sustentável, e não apenas econômica como tem sido criticado o desenvolvimento turístico brasileiro iniciado nos fins dos anos 60, mas sim um desenvolvimento sistêmico e equilibrado entre o social, cultural, ambiental, político e econômico, como ferramenta possível e conciliadora dos demais desenvolvimentos.

Nesse sentido, o modelo da gestão descentralizada e o pensamento estratégico do Ministério do Turismo realmente tem sido um marco na Política Nacional do Turismo. A formação do Conselho Nacional do Turismo - CNT cuja composição procura envolver diversos atores sociais do setor, inclusive representações do governo federal, incluindo o próprio Ministério da Cultura, tem sido uma conquista em andamento. Esse diálogo legitimado entre os ministérios é algo novo no cenário governamental.

Como pode ser percebido no anexo E, na Tabela de Participação das Entidades que compõem o CNT nas Câmaras Temáticas, nota-se que o Ministério da Cultura, participa pouco das Câmaras Temáticas - CT(s), as quais são instâncias importantes de discussão e instrução para orientar novas diretrizes e ações do MTur. O Ministério da Cultura participa oficialmente apenas da Câmara de Segmentação. De acordo com documento que define as Câmaras Temáticas, estas são "uma forma de agrupamento das instituições que compõem o Conselho Nacional do Turismo, segundo temas, com o objetivo de identificar e discutir as questões fundamentais do setor e propor ações para resolução dos problemas e entraves, necessários à consecução da Política Nacional do Turismo. Cada Câmara é constituída por representantes das entidades membros do Conselho Nacional, que tenham afinidade com o tema proposto e por outros indicados e referendados por esses Conselheiros. 
Com o propósito de iniciar a identificação das necessidades e promover discussões em busca de soluções para o setor" (CNT/MTur, 2004).

Até junho de 2005, foram instaladas 10 Câmaras Temáticas: 1. Câmara de Legislação, 2. de Regionalização, 3. de Qualificação Profissional, 4. de Financiamento e Investimento, 5. de Segmentação, 6. de Infra-estrutura, 7. de Promoção e Apoio a Comercialização, 8. de Qualificação da Superestrutura, 9. de Turismo Sustentável e Infância e 10. Tecnologia da Informação. Dessas Câmaras, resultam ainda os Grupos Técnicos de Trabalho, por exemplo, a Câmara de Segmentação compreende os 7 grupos: Ecoturismo, Turismo Cultural, Turismo de Aventura, Turismo de Pesca, Turismo Náutico, Turismo Rural, Turismo Social. O relatório da $3^{\mathrm{a}}$. Reunião do GTT de Turismo Cultural traz uma proposta do MTur para o turismo cultural no Brasil, utilizando a seguinte definição como marco conceitual:

"O segmento turístico denominado turismo cultural compreende atividades turísticas que se efetuam com o objetivo de vivenciar 0 conjunto de características e elementos distintivos do patrimônio histórico-cultural e eventos culturais, valorizando e promovendo os bens materiais e imateriais da cultura".

De acordo com Márcia Sant'Anna (Entrevista 1, 2005) esse documento já foi reescrito pelo Ministério da Cultura com nova abordagem e novamente reenviado ao GTT de Turismo Cultural, o que ela não sabe e se será acatado pela área de turismo.

A Câmara de Legislação está desenvolvendo o Anteprojeto da Lei Geral do Turismo, que se encontra na $7^{\text {a }}$ versão, sendo construído por meio de contribuições de vários setores e principalmente do Ministério do Meio Ambiente, alterando substancialmente o texto inicial. Essa também seria uma discussão importante de interface com o Ministério da Cultura.

O Ministério da Cultura tem estado ausente nas reuniões do Conselho Nacional de Turismo, das oito reuniões realizadas o MinC compareceu a apenas quatro, fato constatado na análise da Lista de Presença das Entidades nas reuniões do Conselho Nacional de Turismo, como pode ser averiguado no anexo F.

Durante o trabalho de campo, questionou-se sobre a ausência do MinC às reuniões do Conselho Nacional do Turismo, por entender que essa participação também é de extrema importância na construção de uma interação 
responsável entre turismo e cultura, sendo o Ministério da Cultura via Iphan, um conhecedor profundo do patrimônio cultural brasileiro e dos principais dilemas desta relação, podendo assim orientar o MTur num desenvolvimento adequado e sustentável, do ponto de vista cultural. Reveladoras foram as repostas advindas deste questionamento, o que refutou umas das hipóteses iniciais desta pesquisa, que era o conflito de linhas de pensamento, mesmo que se perceba uma relação ressabiada, resquício construído em resposta ao crescimento turístico equivocado que o Brasil promoveu desde os anos 60/70, parece que um compromisso vem se firmando entre os Ministérios, o que a Coordenadora do Conselho Nacional de Turismo, Marta Feitosa, muito bem metaforizou, o "Ministério do Turismo e o Ministério da Cultura estão se namorando, mas pode dar casamento" (Entrevista 2, 2005).

Outro problema unanimemente apontado foi o déficit de recurso humano do Iphan/MinC, principalmente no que diz respeito ao Departamento de Patrimônio Imaterial que ainda está se implantando, limitação conhecida pelos técnicos do Ministério do Turismo. A diretora do DPI, Márcia Sant'Anna (Entrevista 1, 2005) assume que a participação do Ministério da Cultura no CNT está deixando a desejar, porém considera que o conselho é um fórum importantíssimo de discussão, sendo a ausência por razão mesmo de pessoal e de inúmeras demandas e atividades sobrepostas. Segundo ela, o Iphan tem uma carga interna de trabalho e não pode se dedicar a "mudar a mentalidade da área de turismo, não podendo estar cotidianamente envolvido". Outro fato é o posicionamento do próprio Iphan de que "as políticas de preservação do patrimônio, tanto nos aspectos materiais ou imateriais, não podem estar focadas unicamente nas atividades turísticas". "Essas políticas têm de estar voltadas para uma preservação enraizada na vida cotidiana das populações, das cidades onde esse patrimônio se encontra... Preservar em primeiro lugar esse patrimônio para as pessoas que estão vivendo com ele e que o estão produzindo. É preciso que isso esteja imbricado na vida, no cotidiano social e econômico das populações, e não apenas em uma preservação para turistas", ponderou Sant 'Anna (Entrevista 1, 2005).

A questão ainda decorre de outros problemas como o desmantelamento do Estado e a "necessidade de reestruturação do Estado democrático e de direito, ampliando a capacidade de atuação do governo", como bem relata a 
entrevistada Ana Cláudia Lima e Alves (Entrevista 3, 2005) gerente de Registro do Departamento de Patrimônio Imaterial do Iphan.

Mesmo que ainda não exista efetivamente um plano conjunto e integrado, com interfaces definidas e claras, é importante ressaltar que o Ministério do Turismo tem orientado suas políticas dentro dessa configuração de parcerias, o que pode ajudar a conduzir a política pública nacional de turismo para essa direção. Por exemplo, essa existência de um planejamento com bases compartilhadas e de um mecanismo de articulação e de confluências de campos de "poder" no termos de Bourdieu (2004), garantidos pelo MTur no modelo denominado "Superestrutura do Turismo", resultante de pesquisas e de um trabalho de concepção de profissionais qualificados do Departamento de Planejamento e Avaliação do Turismo, ligado a Secretaria de Políticas de Turismo/MTur.

O modelo do Conselho Nacional de Turismo constitui a base para a formação dos Fóruns/Conselhos Estaduais de Turismo. Em última instância, os efeitos multiplicadores do modelo descentralizado e participativo devem promover essa configuração dentro das esferas regionais e municipais, com a formação dos Conselhos Regionais e dos Conselhos Municipais. Essa etapa, ainda encontra-se em fase de expansão, sendo que algumas regiões e municípios já desencadearam o processo, assumindo suas responsabilidades e realizando uma atitude pró-ativa, sem esperar a ação do Governo Federal para só então agir reativamente. É o caso, do Fórum do Turismo do Mato Grosso do Sul, que possui representação do Sindicato dos Artesãos, e os COMTUR (s) Conselhos Municipais de Turismo das cidades de Aquidauana, de Campo Grande, de Corumbá, de Bonito, de Dourados e Miranda e ainda as Câmaras Regionais: Câmara Técnica de Turismo da Região Norte - COINTA, a Câmara Técnica de Turismo da Região da Costa Leste - UNIPAR e a CONTURB Serra da Bodoquena, todos integrantes do Fórum. A maioria dos Fóruns ainda não tem essa disseminação do modelo dentro do estado, formando os conselhos regionais e conselhos municipais, nas cidades e regiões identificadas como turísticas ou com potencial para desenvolver.

Sem dúvida, o modelo propõe uma articulação inovadora e de vanguarda estabelecendo uma composição tripartite, unindo iniciativa pública, privada e terceiro setor, um grande mérito do MTur, legitimando seu papel 
articulador, definido no Plano Nacional de Turismo. No entanto, como já visto, a prática depende de processos mais amplos, envolvendo sensibilização, articulação, mobilização e participação efetiva e principalmente flexibilização e vontade política dos diversos setores, inclusive de parcerias da própria esfera federal, estadual e municipal. Se fizermos uma análise atenta à composição dos 27 Fóruns/Conselhos Estaduais, no que diz respeito à participação do terceiro setor, espaço teórico de inclusão da comunidade local, das associações de artesanato, dos representantes dos saberes, fazeres, das celebrações e dos lugares, verifica-se que o setor ainda está preterido. Segundo entrevista com a coordenadora do Conselho Nacional de Turismo, Marta Feitosa (Entrevista 2, 2005), muito dessa ausência de representação nos estados e municípios resultam da falta de entidades organizadas.

Essa análise sobre a participação do terceiro setor nos Estados e das associações representativas das comunidades seria motivo de um novo estudo, até porque, existe uma grande confusão do que é entendido como terceiro setor, incluindo na composição dos Fóruns em alguns estados o sistema S (Sebrae, Senai, Senac e etc) e Universidades Federais, como terceiro setor. Para tanto, vamos redimensionar essa análise apenas aos 6 casos de registro de Patrimônio Imaterial e às respectivas associações que representam os detentores desses conhecimentos em seus estados. Em posse da composição dos Fóruns/Conselhos Estaduais dos Estados onde estas práticas estão inseridas, nenhuma das associações representativas desses saberes participa diretamente da composição dos respectivos Fóruns/Conselhos, ou seja, não estão no centro das decisões e construções de planos/programas/ações e atividades desenvolvidas para o Estado sob a orientação do Governo Federal, via Ministério do Turismo.

Como exemplo, ao abrir a página oficial que promove o turismo no Estado do Espírito Santo, a imagem das panelas seculares de barro saltam aos olhos dos internautas/turistas, carregada de significados e valores, as panelas de goiabeiras permeiam à cultura capixaba, considerada um conhecimento indígena milenar daquela região. O sítio arqueológico de Goiabeiras guarda os cacos de cerâmica que contam essa história da nossa terra bem mais velha que 500 anos. Nesse sentido, Ariano Suassuna, em uma palestra na UnB em 1999, registrada no vídeo documentário "aula espetáculo" faz uma crítica a um 
cartaz das comemorações dos 500 anos do Brasil, intitulado "Arte no Brasil uma história de 5 séculos", de acordo com ele todo o passado indígena e rupestre do Brasil tem sido ignorado, como é assim, os sinais rupestres marcados na serra da Capivara, que só recentemente têm sido valorizados.

Em uma das campanhas publicitárias do Estado do Espírito Santo, denominada: Rota da Moqueca, o maior símbolo é a própria panela. Mesmo assim, a Associação das Paneleiras de Goiabeiras não faz parte da Composição do Conselho Estadual de Turismo - CONTURES (confira no anexo G). Tudo bem que não seja uma associação estadual, que represente amplamente outras associações de artesões, mas também não há na composição nenhuma associação de artesãos que as representem diretamente. No entanto, sua imagem é utilizada como símbolo do turismo capixaba, gerando movimentação de turistas e impactos diretos para essa comunidade, exigindo uma ampliação de produção e interferindo no seu cotidiano e processos culturais. Será que essa comunidade não deveria mesmo fazer parte desse modelo descentralizado, inclusive como forma de garantir a expressão dessas pessoas, orientando políticas que possam desenvolver essa associação do ponto de vista social? As panelas são confeccionadas em um ambiente com condições difíceis de trabalho, por vezes, insalubres, como registram as fotos no anexo $H$, feitas pelas Especialistas do Ministério do Turismo/Coordenação de Produção Associada ao Turismo, Tatiana Petra e Bruna Neiva, durante visita técnica e de inventariado à Associação das Paneleiras de Goiabeiras.

O Ofício das Paneleiras de Goiabeiras foi o primeiro bem cultural brasileiro reconhecido como Patrimônio Imaterial, registrado no Livro dos Saberes, em 20 de dezembro de 2002. O Registro foi feito a pedido da Associação das Paneleiras de Goiabeiras e pela Secretaria Municipal de Cultura de Vitória, Espírito Santo.

O Registro de Bens Culturais de Natureza Imaterial também instituído pelo mesmo Decreto $n^{\circ} 3.551$, de 4 de agosto de 2000, é o instrumento legal para o reconhecimento e a valorização do patrimônio cultural imaterial brasileiro. Os bens registrados são inscritos em algum dos 4 Livros de Registro, de acordo com os aspectos e dimensões que necessitem de proteção: os Saberes, as Celebrações, as Formas de Expressão e os Lugares. Atualmente, 
três registros estão inscritos no Livro dos Saberes: o Ofício das Paneleiras de Goiabeiras, o Modo de Fazer da Viola-de-Cocho e o Ofício das Baianas de Acarajé. No Livro das Formas de Expressão estão dois, a Arte Kusiwa Pintura Corporal e Arte Gráfica Wajãpi e o Samba de Roda no Recôncavo Baiano. No Livro das Celebrações somente o Círio de Nazaré.

O livro dos lugares é destinado a garantir a preservação de práticas sociais legitimadas nos lugares, não necessariamente lugares edificados, sendo mais adequado para estes o instrumento do tombamento. Essa dimensão sutil dos lugares ainda está em fase de aperfeiçoamento pelo IPHAN, considerado de grande importância para preservar um lado mais fragilizado dos "lugares" instituído em seus significados, usos e práticas, que se eliminados do local são completamente perdidos, como é o caso dos usos de praças, de espaços públicos, de feiras públicas, ou mesmo de outros espaços, parafraseando o poeta Carlos Drumond de Andrade, como o é "uma pedra no meio do caminho", carregada de significados e história. Segundo a diretora de registro do Iphan, Ana Claúdia (Entrevista 3, 2005), um dos exemplos "é o caso do Mercado do Recife, que foi transformado em um mercado de artesanato, com outra dinâmica completamente diferente, onde possivelmente se perderam muitas práticas culturais, muitos saberes daquela gente que comercializavam ali alimentos e produtos relacionados ao mercado e foram expulsos de lá". Esse movimento de higienização, clean, de forte influência americana, é o que a pesquisadora nota que muitas vezes acontece com as prefeituras que resolvem limpar e organizar uma praça e acabam por destruir relações construídas ao longo do tempo naquele lugar.

O registro do modo de fazer o acarajé foi requerido pela Associação de Baianas de Acarajé e Mingau do Estado da Bahia, juntamente com o Centro de Estudos Afro-Orientais da Universidade Federal da Bahia e o Terreiro llê Axé Opô Afonjá. O Samba de Roda no Recôncavo Baiano, pela Associação Cultural do Samba de Roda Dalva Damiana, pelo Grupo Cultural Filhos de Nagô e pela Associação de Pesquisa em Cultura Popular e Música Tradicional do Recôncavo. No Mato Grosso e Mato Grosso do Sul, o registro da Viola-decocho foi encaminhado por interessados e comunidades residentes nos Estados de Mato Grosso e Mato Grosso do Sul e, em especial, por instrumentistas e artesãos detentores da arte de fazer a Viola-de-Cocho. No 
Amapá, a Arte Kusiwa - Pintura Corporal e Arte Gráfica Wajãpi, foi proposta pelo Conselho das Aldeias Wajãpi - Apina; pelo Núcleo de História Indígena e do Indigenismo da Universidade de São Paulo; pelo Núcleo de Educação Indígena do Governo do Estado do Amapá; e pelo Museu do Índio da Funai. Em Belém do Pará, o registro do Círio de Nossa Senhora de Nazaré, foi requerido pela Arquidiocese de Belém, pela Diretoria das Festividades de Nazaré e Obras Sociais da Paróquia de Nazaré.

Segundo Ana Claúdia ao palestrar na UnB sobre culinária como patrimônio imaterial, em junho de 2005, "trata-se de dar conta de descrever, identificar e documentar o bem cultural como um fato cultural completo, com todas as suas articulações e associações". Envolve etapas e práticas culturais complexas, onde todo o processo faz parte do registro associado à expressividade daquele objeto de representação, que não é apenas o "modo de fazer o acarajé" ou "o acarajé", "são todos os saberes e fazeres envolvidos nas práticas das baianas de acarajé, em associação com a religiosidade do candomblé", que é origem desta culinária, nota a pesquisadora. O mesmo refere-se ao registro do modo de fazer a viola-de-cocho, no MT e MS, "que está associado às formas de expressão do Cururu, que é música e o siriri, que é a dança, elementos referidores de identidade de ambos os estados", contextualiza.

Segue um breve resumo do processo complexo que envolve o bem registrado, informações sintetizadas retiradas do Programa Nacional do Patrimônio Imaterial disponível pela internet.

A panela de barro de goiabeiras: A fabricação artesanal de panelas de barro utiliza-se de uma técnica de cerâmica de origem indígena, possivelmente das tradições Tupi-Guarani e Una, caracterizada pela modelagem manual, queima a céu aberto e aplicação de tintura de tanino. É o suporte físico indispensável para fazer e servir a moqueca capixaba - referência obrigatória da culinária e ícone da identidade cultural regional, mas as ações destinadas a manter a continuidade deste ofício levam em conta também todo o processo que envolve esse objeto representativo, desde a organização comunitária, a prospecção de mercados e a preservação do ambiente que guarda suas matérias-primas 
essenciais: a jazida de argila ou barreiro e o mangue de onde é extraída a tintura de tanino.

A Arte Kusiwa: é uma técnica de pintura e arte gráfica própria da população indígena Wajãpi, do Amapá. Em 2003, no ano seguinte ao registro, recebeu da Unesco o título de Obra-prima do Patrimônio Oral e Imaterial da Humanidade. Constitui um sistema de comunicação e linguagem única. Os grafismos podem ter como suporte o corpo humano, mas também cestos, cuias, tecelagem, bordunas e objetos de madeira. Os múltiplos significados nos níveis sociológico, cultural, estético, religioso e metafísico indicam que a importância da Arte Kusiwa extrapola o seu lugar de arte gráfica e, efetivamente, engloba 0 vasto e complexo sistema que envolve sua maneira específica de compreender, perceber e interagir com o universo. O apoio à continuidade dessa forma de expressão está sendo feito por meio de diversas ações: elaboração de campanhas de sensibilização e informação; difusão, seletiva e controlada por seus detentores, da Arte Kusiwa; diagnóstico permanente do processo de revitalização da cultura oral; implantação de um Centro de Referências da Cultura Wajãpi; e, finalmente, a formação de professores indígenas, responsáveis pela alfabetização das crianças em sua língua materna.

O Círio de Nazaré: é uma celebração religiosa de Belém do Pará, que apresenta uma estrutura complexa agregando diferentes celebrações e festividades, antes e depois do evento principal - a procissão do Círio. Essas práticas têm desdobramentos regionais e congregam, anualmente, no segundo domingo de outubro, em torno de um milhão e meio de pessoas na cidade de Belém, devotos, romeiros ou promesseiros, além de turistas e curiosos de todas as partes do Brasil e até de países estrangeiros. A festa instituída em 1793 é marcada pelo sentido da rememoração do encontro da imagem de Nossa Senhora de Nazaré pelo caboclo Plácido. A celebração, desde a origem, está envolta por práticas profanas, entre elas a montagem de um arraial dedicado historicamente ao comércio de alimentos e produtos regionais. 
O Samba de Roda baiano: é uma expressão musical, coreográfica, poética e festiva das mais importantes e significativas da cultura brasileira, o samba envolve religião, culinária e festa. Presente em todo o estado da Bahia, ele é especialmente forte e mais conhecido na região do Recôncavo. Seus primeiros registros, já com esse nome e com muitas das características que ainda hoje o identificam, datam dos anos 1860, e influenciou a fase pioneira do samba no Rio de Janeiro. O Samba de Roda pode ser realizado em associações festivas, rituais para caboclos em terreiros de candomblé, mas também em qualquer momento, como uma diversão coletiva, pelo prazer de sambar.

O ofício do acarajé: consiste em uma prática tradicional de produção e venda em tabuleiro das chamadas comidas de baiana ou comidas de azeite, em que se destaca o acarajé, um bolinho de feijão fradinho, frito no azeite de dendê. A feitura do acarajé foi trazida pelas escravas negras libertas no período colonial, proporcionando a sobrevivência após a abolição da escravatura. No decorrer dos séculos essa comida, que teve uma origem sagrada, associada ao culto de divindades do candomblé, passou a marcar toda a sociedade baiana como um valor alimentar integrado à culinária regional. Os elementos essenciais do Ofício das Baianas de Acarajé compreendem os rituais envolvidos na produção do acarajé, na arrumação do tabuleiro e na preparação do lugar onde as baianas se instalam; os modos de fazer as comidas de baiana; o uso do tabuleiro para venda das comidas; a comercialização informal em logradouros, feiras e festas de largo; o uso da indumentária própria das baianas, como marca distintiva de sua condição social e religiosa, presente especialmente nos panos da costa, nos turbantes, nos fios de contas e outras insígnias.

Viola-de-cocho: é um instrumento musical singular quanto à forma e sonoridade, produzido exclusivamente de forma artesanal, com a utilização de matérias-primas existentes na Região Centro-Oeste do Brasil. O instrumento integra o complexo musical, coreográfico e poético do cururu e do siriri juntamente com o ganzá (reco-reco de taquara) e o tamborim ou mocho (banco cujo assento de couro é percutido com baquetas de madeira) - cultivado por segmentos das camadas populares como diversão ou devoção a santos católicos. Como bem cultural corresponde a um modo de fazer único e 
especial, caracterizando um ofício com suas formas de produção e de execução artístico-musical, geralmente associadas a formas de expressão específicas, dentre as quais se destacam o cururu e o siriri.

Como explica o presidente do Iphan, Antônio Augusto Arantes (entrevista 4, 2005) "o registro é apenas um ponto de partida: a formalização do compromisso do governo federal com o desenvolvimento de ações de salvaguarda. Em si mesmo, apenas como ato administrativo, ele pode ser inócuo. O importante são os compromissos e responsabilidades que se criam a partir dele, colocando lado a lado, o Estado e a sociedade, diante da responsabilidade por sua salvaguarda e proteção". Portanto, o registro significa o reconhecimento da importância do "bem" para identidade cultural do povo.

Porém, além do registro, a política de preservação do patrimônio cultural imaterial conta com outros instrumentos, o INRC - Inventário Nacional de Referências Culturais e os Planos de Salvaguarda, envolvendo oficinas e discussões com os grupos. Nesse sentido, outras ações complementares estão sendo dirigidas à salvaguarda dos bens registrados, como as ações que "financia, apóia e estimula, prioritariamente, projetos inseridos nas seguintes linhas": 1. Pesquisa, documentação e informação, 2. Sustentabilidade, 3. Promoção e 4. Capacitação, bem como as ações de fomento, previstos no PNPI. Ao enumerar suas principais diretrizes, a política de fomento reforça a idéia de que os produtores e detentores do patrimônio cultural imaterial devem ser os maiores beneficiados pela proteção, de forma a promover a cidadania e o desenvolvimento social desses grupos, estendendo os benefícios gerados pela preservação das coisas às pessoas, no caso, coisas não tão concretas, como os saberes e fazeres, os significados das celebrações e dos lugares, que se encontram incrustados nas almas das pessoas, sendo elas os seus verdadeiros guardiões, merecedores de condições mais dignas de vida e de respeito.

O que pode ser reforçado pelas diretrizes que norteiam a política de fomento do PNPI como segue:

- Promover a inclusão social e a melhoria das condições de vida de produtores e detentores do patrimônio cultural imaterial. 
- Ampliar a participação dos grupos que produzem, transmitem e atualizam manifestações culturais de natureza imaterial nos projetos de preservação e valorização desse patrimônio.

- Promover a salvaguarda de bens culturais imateriais por meio do apoio às condições materiais que propiciam sua existência, bem como pela ampliação do acesso aos benefícios gerados por essa preservação.

- Implementar mecanismos para a efetiva proteção de bens culturais imateriais em situação de risco.

- Respeitar e proteger direitos difusos ou coletivos relativos à preservação e ao uso do patrimônio cultural imaterial.

A tramitação dos processos de registro obedecem a critérios próprios, a instauração do processo tem início com a abertura de um Dossiê de Estudos. Após a conclusão da instrução técnica, o dossiê é encaminhado ao Conselho Consultivo do Patrimônio Cultural e só então recebe um número de processo, atendendo a uma série de requisitos de abertura e de tramitação técnica.

3.4. Patrimônio imaterial: protagonização nos discursos e imagens do turismo

Que imagem do Brasil tem sido ilustrada pelo setor do turismo? Atualmente, para aquém de um país exótico e erótico, de florestas, índios, turismo sexual fácil, especialmente, o infantil, de "bundas" e "peitos", outras imagens do país têm conquistado espaço e atraído um novo turista estrangeiro. Nossa gente, nossa cultura, nossa culinária, nossas festas, nossas tradições, nosso patrimônio cultural, nossos saberes e fazeres, nossa diversidade natural e cultural, nossas caras: japonesas (maior colônia), árabes (maior colônia), italianas, portuguesas, francesas, africanas, nossa "cara brasileira", um país onde todo o mundo se reconhece, de cultura híbrida, formada pela mistura desde a sua formação. Os discursos sobre a biodiversidade e a diversidade cultural brasileira como um recurso único para o desenvolvimento do turismo tem sido um enunciado que encontra receptividade nos fóruns internacionais.

O reposicionamento da imagem do turismo brasileiro é uma das grandes conquistas do Plano Nacional do Turismo, essa ação faz parte do Programa de Promoção Nacional e Internacional do Turismo Brasileiro e do Programa de 
Reposicionamento da Imagem Brasil, ligados ao Macroprograma-6, de Promoção e Apoio à Comercialização. "A promoção do turismo brasileiro no mercado internacional terá como conceito estratégico a diversificação da imagem do país... Os programas de promoção e marketing terão como essência a qualidade e a diversidade da produção cultural brasileira, além de nossa diversidade étnica, social e natural" (PNT, 2003:42).

Ressalta-se então, que no plano das imagens e dos discursos oficiais apresentados pelo governo federal, a cultura brasileira tem sido direcionada aos holofotes da fala e dos cartões postais como um dos principais atrativos e diferenciais para o desenvolvimento do turismo brasileiro (Ver anexos 7 e 8). No campo das aparências e das elocuções, portanto, pode-se perceber que o patrimônio imaterial vem ocupando a cena das atrações turísticas, as exuberantes baianas e seu acarajé, as panelas seculares de barro, a artesanal Viola-de-cocho, os traços da Arte Kusiwa - Pintura Corporal e Arte Gráfica Wajãpi, o contagiante Samba de Roda no Recôncavo Baiano e a festa do Círio de Nazaré, de Belém do Pará.

À medida que se muda o foco, as ações de promoção começam a "orientar a construção do Brasil como destino turístico", calcada em um "país moderno, com credibilidade, alegre, hospitaleiro, capaz de proporcionar lazer de qualidade, novas experiências aos visitantes, realização de negócios, eventos e incentivos" objetivando um país competitivo internacionalmente. As festas, a cultura popular, o povo brasileiro, suas tradições e patrimônio também começam a estampar a cara do Brasil nos cartões postais, diminuindo assim o apelo ao erotismo da mulher brasileira, que apesar de menor intensidade ainda tem sido divulgado no exterior, talvez, povoadas no imaginário mundial desde os tempos das primeiras impressões relatadas na carta de Pero Vaz de Caminha:

"Ali andavam entre eles três ou quatro moças, bem novinhas e gentis, com cabelos muito pretos e compridos pelas costas; e suas vergonhas, tão altas e tão cerradinhas e tão limpas das cabeleiras que, de as nós muito bem olharmos, não se envergonhavam... E uma daquelas moças era toda tingida de baixo a cima, daquela tintura e certo era tão bem feita e tão redonda, e sua vergonha tão graciosa que a muitas mulheres de nossa terra, vendo-lhe tais feições envergonhara, por não terem as suas como ela... Outra trazia ambos os joelhos com as curvas assim tintas, e também os colos dos pés; e suas vergonhas tão 
nuas, e com tanta inocência assim descobertas, que não havia nisso desvergonha nenhuma..."

Ao longo da história, parece que essa imagem foi sendo reforçada por campanhas de marketing e políticas equivocadas de desenvolvimento turístico internacional, não somente pela Embratur, mas como órgão máximo, critica Santos Filho nesta citação: "a idéia de vender uma imagem de fetiche sobre o Brasil para os estrangeiros fez a Embratur desenvolver e priorizar uma publicidade focada na mulher brasileira e sua beleza estética, estampados em posters da entidade, de 1966 até 1986". (Santos, 2005)

\subsection{Interfaces na atuação entre os "campos" de poder}

Os mais novos registros de Patrimônio Imaterial: a Viola-de-Cocho e o Ofício da Baiana de Acarajé, coincidentemente foram anunciados no âmbito do I Fórum Mundial de Turismo para a Paz e Desenvolvimento Sustentável Movimento Brasil de Turismo e Cultura, realizado em dezembro do ano passado, na cidade de Salvador, Bahia/Brasil, uma sinalização da congruência, mesmo que tímida da inter-relação dessas políticas e seus campos de poder. Isso sugere que uma parte importante dos processos culturais brasileiros estão sendo conduzidos ao desenvolvimento do turismo, nem que sejam, no campo do discurso e da representação visual. Essa interface entre patrimônio imaterial e turismo exposta em um evento de alcance internacional, como foi o caso do I Fórum Mundial de Turismo, muito é reveladora, do ponto de vista da representação simbólica que à cultura brasileira tem adquirido na esfera do turismo.

Segundo Pierre Burdieu (2004), o poder simbólico é um poder invisível, que pode ser exercido com a cumplicidade daqueles que não querem saber que lhe estão sujeitos ou mesmo que o exercem, permitindo obter o equivalente daquilo que é obtido pela força (física e econômica), mas só se exerce se for reconhecido. Interpretando Bourdieu, Lara Santos de Amorim em seu artigo "O registro de manifestações culturais tradicionais" diz que: "a legitimidade e reconhecimento, bem como a produção e manutenção de determinado objeto ou valor cultural, só pode se dar dentro desta rede que interliga os diferentes campos, sem esquecer, que o princípio de legitimidade 
do campo de poder (field of power) costuma estar baseado no poder do capital econômico ou do capital político" (Amorim, 2004). Lara observa que alguns estudiosos acreditam que o folclore é uma das raras práticas que estaria fora do campo de poder, admitindo que o campo cultural, em geral, está intimamente relacionado ao campo de poder. Neste caso, essas práticas culturais atingiram os campos de poder exercendo seu poder simbólico reconhecido como nunca antes o foi, legitimadas nos discursos oficiais e entre muitos profissionais que estão à frente de algumas decisões políticas.

Recentemente, novo evento sobrepôs esses campos. No Salão do Turismo - Roteiros do Brasil, realizado pelo Ministério do Turismo, no mês de Junho de 2005, na cidade de São Paulo, o IPHAN esteve presente, com a exposição Patrimônio Imaterial - Primeiros Registros, ocupando 155, 32 metros quadrados dentro dos 3 mil metros do espaço "Vitrine Brasil", projeto da Secretaria de Programas de Desenvolvimento do Turismo do Ministério do Turismo. O projeto concebido pela arquiteta Ana Zerbini, consultora da Unesco junto à Coordenação de Produção Associada ao Turismo do MTur ilustra bem essa sobreposição de espaços de poder, podendo ser observando no anexo I, ao final deste trabalho. Daí, a importância de profissionais com qualificação e saber especializado que possam promover essas interfaces como foi o caso do projeto "Vitrine Brasil", que contou com a parceria do Ministério da Cultura/IPHAN e de outros 9 parceiros, apresentando assim 9 ambientes cenográficos com os patrimônios brasileiros da humanidade, bem como, os 6 bens registrados como patrimônio imaterial brasileiro, por meio de 24 painéis informativos. Para isso, a diretora de registro do IPHAN (Entrevista 3, 2005) defende que todo profissional do turismo precisa se preocupar com um olhar transversal sobre as coisas, bem como com o conhecimento especializado, tendo "a obrigação e o dever de se informar sobre os bens culturais locais, devendo procurar ter uma aproximação com os grupos produtores e detentores desses saberes, por meio de um olhar sensibilizado para a manutenção e a continuidade desses bens" (Entrevista 3, 2005). O objetivo do Salão do Turismo foi promover e incentivar a organização e comercialização dos Roteiros do Brasil, programa lançado em abril de 2004.

Em um exercício de abstração para localizar onde está o Patrimônio Imaterial dentro da estrutura atual do Ministério do Turismo arrisca-se dizer que 
esta questão tem sido tratada dentro do Departamento de Qualificação, Certificação e de Produção Associada ao Turismo (DQCPAT), mais especificamente pela Coordenação-Geral de Produção Associada ao Turismo (CGPAT).

Figura 2: Estrutura do Departamento de Qualificação e Certificação e de Produção Associada ao Turismo, ligado a Secretaria de Programas de Desenvolvimento do Turismo/MTur.

Para realizar suas ações o DQCPAT definiu o seguinte conceito de Produção Associada: "Produção artesanal, agropecuária ou industrial, que detém atributos naturais e/ou culturais de uma determinada localidade ou região capazes de agregar valor ao produto turístico".

O conceito apesar de reforçar uma identificação da cultura como produto turístico, começa a trabalhar a perspectiva de associação de valor ao produto, o que pode a longo prazo, encaminhar uma relação da cultura como recurso turístico, sendo um meio e não propriamente um fim, transformado em mercadoria.

Foi nesse departamento também que em fevereiro de 2005 foi criado o GTT do Artesanato, um Grupo Técnico de Trabalho, que de certa forma promove a interface entre $\mathrm{o}$ artesanato enquanto patrimônio imaterial e 0 desenvolvimento do turismo, reunindo um grupo de especialistas do Ministério 
do Turismo, do Ministério da Cultura/IPHAN, do Ministério de Desenvolvimento Indústria e Comércio, do CNFCP - Conselho Nacional de Folclore e Cultura Popular, UNESCO, da AECI - Agência Espanhola de Cooperação Internacional e SEBRAE. Dentro de uma ótica transversal somando conhecimentos do Governo Federal e entidades internacionais, procurando romper paradigmas e somar responsabilidades dentro de uma perspectiva compartilhada.

\subsection{A cultura como recurso político, econômico e turístico}

O tema desta breve abordagem é título-síntese da teorização pioneira do diversificado papel da cultura na era global, desenvolvida pelo escritor George Yúdice (2002), que mostra que a globalização revigorou o conceito de cidadania cultural, enunciado este que encontrou receptividades nos fóruns internacionais. Para ele, as novas relações da globalização "deram à esfera cultural, especialmente ao multiculturalismo, um protagonismo maior que em qualquer outro momento da história da modernidade", onde o papel da cultura se expandiu para as esferas política e econômica, "ao mesmo tempo em que as noções convencionais de cultura se esvaziaram" (Yúdice, 2002). Nesse contexto, a cultura se tornou um pretexto para a melhoria sociopolítica e para o crescimento econômico nos atos discursivos dos fóruns internacionais referentes à cultura e ao desenvolvimento locais, operando assim uma transformação para satisfazer o resultado final, o que o autor denomina de "economia cultural", referindo-se ao que Blair intitulou "economia criativa".

Ao citar um exemplo de desenvolvimento cultural no Brasil, no caso, o grupo musical Olodum, conhecido mundialmente, o autor faz uma análise sobre a renovação do Pelourinho, de local histórico para local turístico, marcado pelo deslocando de seus residentes pobres. Recorre-se aí, à "economia criativa, que evidentemente favorece a classe profissional gerenciadora, mesmo quando ela vende seu produto baseado na retórica da inclusão multicultural", observa.

O autor destaca nos discursos do Banco Mundial as idéias da cultura como geradora de renda, por meio do artesanato e do turismo e outros empreendimentos culturais e o patrimônio cultural como gerador de valor. De acordo com Yúdice (2002) quando as poderosas instituições e fundações 
internacionais, como o Banco Interamericano de Desenvolvimento - BID e Banco Mundial, começam a compreender a cultura como uma esfera para investimentos; a cultura e as artes passam a ser tratadas como recurso. "Em outras palavras, a nova fase do crescimento econômico, a economia cultural, também é uma economia política", define Yúdice. A cultura então se transforma "num recurso à medida que é instrumentalizada, tanto por razões econômicas quanto sociais", conclui o autor.

Neste sentido, as regulações governamentais são instrumentos que não devem ser interpretados como "província exclusiva dos governos...,as questões comerciais e as iniciativas não-governamentais demonstram, pelo contrário, que a política cultural também é feita pelas corporações, pela mídia, pelas fundações, pelos políticos e, em alguns casos, até pelos cidadãos" (Yúdice, 2002). Para os principais representantes do Iphan entrevistados nesta pesquisa os cidadãos deveriam ser conduzidos à centralidade dessas discussões, o que infelizmente raramente ocorre na prática, substituídos pela figura dos mediadores, os chamados gestores públicos, são quem decide por eles.

Yúdice (2002) considera que os usos convenientes da cultura é um caminho irreversível, entendendo conveniência no contexto dado à palavra em inglês expediency no Oxford english dictionary, como adaptabilidade às circunstâncias ou condições do caso. A obra do autor traduzida no Brasil traz o título "A Conveniência da Cultura - Usos da Cultura na Era Global". Para isso, ele aponta possíveis caminhos como alguns movimentos demonstram que é possível apropriar-se dos avanços tecnológicos e da globalização e cultivar uma comunidade interativa e de oposição. Cabendo às instituições e ao terceiro setor evitar a transformação dos bens públicos em propriedade privada, sendo importante para tanto uma alfabetização crítica.

Ao defender a idéia de uma América Latina mais organizada e fortalecida Yúdice (2002) cita o projeto da Associação Internacional Arte Sem Fronteiras (ASF), uma organização brasileira com o propósito de integrar os povos latino-americanos, defendendo a importância de entidades como esta, que sirvam como um fórum onde diferentes atores possam falar uns com os outros e debater os méritos ou inconveniências relativos à sua interpretação de cultura e seus usos, ao mesmo tempo que garanta a representação das populações marginalizadas. 
Por último, Yúdice (2002) mapeia uma série de ações que estão acontecendo, mas observa que não tem havido articulação efetivas e suficientes nas regiões e países em jogo. Citando Getino (2001) assinala que as demandas das culturais regionais e locais estão crescendo, e Gohn (2000) acrescenta que os movimentos como o dos zapatistas em Chiapas e o dos sem-terra no Brasil começaram a utilizar a mídia para tornar mais notórios os seus atos. Trata-se de entender o mecanismo da globalização e da economia cultural e apropriar-se de forma favorável aos interesses do local. Nesse contexto, o processo de globalização insere-nos a novos níveis de diversidade emergindo como nunca o local, "em conseqüência, a globalização nos torna conscientes do próprio volume, da diversidade e das muitas facetas da cultura", esclarece Featherstone. Para ele "se existir uma cultura global, seria melhor concebê-la não como uma cultura comum, mas como um campo no qual se exerçam as diferenças, as lutas de poder e as disputas em torno do prestígio cultural" (Featherstone, 1997). É desse campo relacional invisível que muito tratou esta pesquisa, que considera que no ato discursivo as culturais locais ocuparam a centralidade, ainda estando por vir, a centralidade das decisões, que reivindicam processos mais amplos e mudanças substanciais na forma impositiva que as políticas públicas foram conduzidas no Brasil até hoje. 
Da mesma forma que a economia cultural é um caminho sem volta nos usos da cultura em tempos de globalização, o desenvolvimento do turismo no Brasil também parece irreversível. Algumas localidades estão sujeitas mesmo a essas intervenções, que promovem uma miscelânea de estímulos, confrontos e reações, sendo que a cultura do lugar, portanto, a alma do lugar, se envolve nesse processo, podendo se beneficiar ou não dele. Essa interface responsável pode ocorrer se o desenvolvimento do turismo for bem planejado, articulado entre os diferentes setores, sob uma perspectiva transversal e interdisciplinar, focado principalmente no respeito às comunidades envolvidas e na sustentabilidade do processo, aspectos frisados por todos os entrevistados desta pesquisa e reforçados como possibilidade positiva como visto nas noções de pós-modernidade e globalização trazidas por esta pesquisa. Encarar esse impacto de uma vez por todas, já que esta relação entre cultura e turismo é inevitável, pode mudar os rumos do desenvolvimento do turismo no Brasil, fortalecendo o local diante da globalização, o que pode contribuir para imprimir uma nova prática, calcada em novos aprendizados e rompimento de barreiras e padrões arraigados nas políticas e nas pessoas que as conduzem.

Verificou-se por meio da pesquisa realizada que o objetivo principal deste estudo foi alcançado: identificar e analisar o teor de políticas de preservação do patrimônio imaterial. Observou-se que esses bens culturais já estão ocupando os discursos e imagens do turismo, caminhando para o diálogo entre os órgãos do governo federal, mas ainda não como políticas integradas e efetivas, com vistas a um desenvolvimento da política nacional de turismo como instrumento de preservação real do patrimônio cultural. Para tanto, não existe um programa/plano ou atividade sendo desenvolvidos para melhor regular essa relação, no sentido de criar recomendações, orientações sobre intervenções turísticas relativas ao patrimônio imaterial, normas, projetos interpretativos, avaliações de impactos e monitoramento, enfim novas práticas conjuntas de preservação, que reúnam recursos, conhecimento e políticas. O 
objetivo secundário desta pesquisa pretendeu promover a discussão sobre a interface entre as duas políticas, e por conseqüência, entre os dois órgãos federais: Ministério da Cultura e Ministério do Turismo, o que também foi alcançado por meio das entrevistas que promoveram o diálogo acerca do Patrimônio Imaterial e o Turismo, entre especialistas expressivos dos dois órgãos, identificando assim os principais dilemas desta relação.

A relação entre Patrimônio Imaterial e o desenvolvimento do turismo no âmbito das políticas públicas do Governo Federal se dá de forma ressabiada por meio de uma aproximação cautelosa e cuidadosa por parte do Ministério da Cultura, que ainda vê no desenvolvimento do turismo no Brasil vícios estruturais, herdados da política de turismo desde os anos 60/70 advindos dos rumos adotados pela EMBRATUR, transformando os lugares para "O Turista". Verificou-se por meio desta pesquisa que o desenvolvimento do turismo no Brasil ainda carrega resquícios de políticas voltados prioritariamente para 0 turista, enfocando no turista o desenvolvimento de novos destinos e produtos, contrário ao pensamento internacional de associar cada vez mais o desenvolvimento cultural, ao social e ao econômico.

A primeira hipótese levantada de que o patrimônio imaterial já vinha emergindo no cenário do turismo, mas muito mais nas fases de agenda, discussão e preocupação do que de construção de práticas e políticas efetivas e integradas foi totalmente confirmada. Nesse aspecto, mesmo que o discurso do governo federal atual seja de gestão participativa e descentralizada, percebe-se que o terceiro setor, as comunidades e a sociedade civil organizada ainda não estão fortalecidos no novo modelo, que tem privilegiado o setor privado. A segunda hipótese de que a política de patrimônio imaterial pode encontrar no turismo um aliado, tanto para a proteção do bem registrado como divulgação e promoção, previstos no art. 6 do Decreto n 3.551 de 4 de Agosto de 2000, foi confirmada também com devidas ponderações feitas pelos técnicos do IPHAN, que acreditam que essa relação deve ser baseada na manutenção dos bens, devendo ser evitada quando esses bens são colocados em risco. Sendo que alguns patrimônios imateriais, como a arte Kusiwa, não devem ser objetos diretos de intervenções turísticas, indicados para estes outras abordagens criativas, como projetos interpretativos, exposição de fotos ou utilização de outras tecnologias que promovam o conhecimento sem, no 
entanto, transformá-lo em "destino turístico" e "produto turístico". Pode-se até derivar novos produtos, como livros, "centro de promoção e referência", mas não sendo aquele povo um produto em si. Foram reveladoras as repostas advindas das entrevistas, o que refutou a última hipótese, pois acreditava-se que a interface entre Turismo e Patrimônio Imaterial era isolada, de silêncio e não de diálogo, sendo mais de conflito entre linhas de pensamento, mas verificou-se ao longo deste estudo que esse diálogo e as ações estão sendo encaminhadas para a integração. Mesmo que se perceba uma relação ressabiada, resquício construído em resposta ao crescimento turístico equivocado que o Brasil vinha promovendo, parece que um compromisso vem se firmando entre os Ministérios do Turismo e da Cultura.

O caminho de uma política pública passa por várias etapas, configuradas em planos/programas/ações e atividades. A promoção é uma delas, talvez uma da mais exploradas no governo federal, não que não seja importante, promover-se, é a partir daí que uma política é disseminada e, portanto, implantada, mas não deve ser a mais importante das etapas, as políticas deveriam estar em constante construção e monitoramento, privilegiando uma perspectiva de continuidade e redirecionamento, de acordo com os impasses identificados podendo reverter caminhos de risco para a sustentabilidade do destino turístico.

Nesse contexto, as interfaces entre patrimônio imaterial e turismo, sempre existiram, e atualmente destacaram-se muito no plano das idéias e imagens, ou seja, no ato discursivo e no apelo das imagens, carregando uma força sedutora aqueles que vêem e ouvem sobre os rumos do turismo brasileiro. Mas essa interação ainda não é pautada por uma política integrada e efetiva, que regule mesmo essa relação, norteada pelo respeito e a promoção da cidadania. Alguns patrimônios imateriais na sua dimensão material podem ser "experienciados" pelos turistas, como o sabor do acarajé, o contagiante samba de roda, o som único da viola-de-cocho, mas outros desses bens não devem virar "produtos", "mercadorias", como já dito, a arte Kusiwa, sendo que nem os detentores desse saber querem essa aproximação. Alguns patrimônios imateriais, conforme ressaltado, tem suas dimensões por demais sensíveis e frágeis, não sendo a melhor promoção transformá-los em produtos. A cultura não é um produto à venda, mas pode ser um "recurso" para um 
desenvolvimento turístico responsável, recurso no sentido de potencialidade. Nem todo bem cultural poderá ser transformado em produto a ser consumido ou exposto nas prateleiras, mas será recurso a ser compreendido, interpretado e conhecido. Transformando o turista consumidor em conhecedor. Ou quem sabe, alternativas que criaram produtos indiretos, como os traços da arte Kusiwa estampados em objetos suveniers para serem lembrados por seu significados e valores, como são hoje as letras japonesas, para ser contada em livros, vídeos documentários, registrados em cartões postais, em exposições de fotos, ou quem sabe, nesse contexto, a performance seja adequada. $O$ contato com a tribo não necessariamente é a única forma de contato com essa realidade. Como promover a proteção, a informação e promoção desses saberes sem destruí-los? Sem pretensões de apontar como deve ser feito, mas sim levantar que essas questões devem ser pensadas para instrução das políticas públicas do turismo, no sentido da continuidade e preservação desses valores, onde a promoção agregue valor e não um preço.

Um turismo que dê lugar a experiência turística, que não se resuma a um turista consumidor de mercadoria, mas consumidor de conhecimento, emoções, valores, capazes de transformar uma relação estimulada como predatória em uma relação harmônica, onde ambos, comunidade e turista, saiam acrescidos dessa experiência aprofundados na alquimia do respeito mútuo. Necessito fazer aqui um parêntese. Recordo-me de uma aula neste curso de pós-graduação em Turismo: Cultura e Lazer com o professor Carlos Delphim, especialista em jardins e arquiteto do IPHAN. Em uma aula aberta, no Jardim Botânico de Brasília, conduziu os alunos a uma experiência de cheiros, cores, texturas e novas percepções e emoções, por meio de informações interpretativas, combinando conhecimento especializado e conhecimento popular, despertando um novo olhar para aquele lugar. Ao pôr do sol, já na saída do Jardim Botânico, estávamos no mesmo carro, três alunas e o professor, quando ele se aproximou de uma cerca amontoada de um tipo de trepadeira e colheu três flores, que na minha memória hoje, tinha uma forma de taça, retirando-lhes os talos, orientou-nos que apreciássemos o mel que aquela flor escondia, revelando um sabor imensurável. Essa experiência única ficou na memória de cada uma de nós, somando um valor especial àquela aula. $\mathrm{O}$ turismo também pode oferecer essas emoções, exigindo qualificação dos 
profissionais, sensibilidade e especialização de conhecimentos, para acompanhar o turista pós-moderno que cada vez mais está se transformando em turista especializado, em busca da profundidade das coisas e dos lugares por onde viaja. Fecho o parênteses...

O presente estudo pretendeu contribuir para o preenchimento de uma brecha de pesquisas entre as relações sobre Turismo e Cultura, principalmente sobre o patrimônio imaterial e o desenvolvimento do turismo no Brasil no atual governo, mas considera essa pequena contribuição como uma pontinha de um iceberg, imenso e em movimento. Longe de considerá-lo um fechamento de discussão, reconhece o campo de estudo e os respectivos conceitos por onde peregrinaram essa monografia um caminho a ser aprofundado por outros estudiosos a fim de contribuir e fomentar com o avanço e construção de políticas com concepções mais abrangentes e participativas.

Acredito que o pensamento acadêmico e crítico podem também se debruçar na construção de um desenvolvimento turístico melhor, que promova a cidadania e dignidade das pessoas envolvidas e não seja mais um setor a reforçar a má distribuição de renda, as desigualdades e a exclusão. Deixemos claro, que o turismo não é nenhuma tábua de salvação, mas pode ser um instrumento político, social, econômico, ecológico e cultural, se bem planejado e conduzido.

Todas as entrevistadas que municiaram esta pesquisa, destacaram que o turismo pode ser um aliado ao desenvolvimento cultural e social se "bem planejado", como que insinuando que uma série de ações está acontecendo, mas ainda não é uma realidade pronta e por assim dizer, bem planejada e desenvolvida de forma cuidadosa. Então, avancemos, deixando o discurso para a prática, considerando que o bom planejamento não possui "receita de bolo", que para cada situação e cada comunidade o processo deve ser pensado de forma única e em conjunto, privilegiando a participação daqueles que formam o lugar turístico. Pois o turismo brasileiro é único, como o é o da Espanha. Não precisamos copiar nada de ninguém, dentro de nossa diversidade somos únicos, e é essa a nossa maior competitividade, como já enuncia o Governo Federal. O que deslocaria uma pessoa lá do outro lado do planeta para viajar até o Brasil? Diriam os japoneses e chineses, já confirmados em pesquisas, que o nosso futebol. Yes! Nós temos Futebol, mas 
não temos só isso, mesmo o futebol é mal explorado enquanto potencial turístico, como turismo segmentado, capaz de atrair estudantes, levantar museus, dinamizar os estádios, criar novas práticas, gerar um projeto interpretativo, provocar experiência que deflagre outras, como um passeio pela nossa culinária, nossa música, nossos costumes.

Através de um planejamento cuidadoso, da implementação sistemática desse planejamento, de uma ordenação e do gerenciamento efetivo e contínuo do turismo, os benefícios podem ser maximizados e os problemas minimizados, como assim prevê parte do Plano Nacional de Turismo, ao dizer "maximizando resultados e racionalizando gastos", infelizmente deixando de lado a minimização dos impactos. "Entretanto, como em qualquer tipo de desenvolvimento, e o turismo não é uma exceção, algumas incertezas são inevitáveis. Cada comunidade deve decidir se pode maximizar os benefícios e minimizar os problemas e aceitar as incertezas dos benefícios e problemas que resultares do desenvolvimento do turismo" (OMT, 2003).

A globalização e o pós-modernismo podem ser utilizados a favor dos conhecimentos locais, que nesse contexto ganharam expressividade e valorização, para isso, torna-se imprescindível garantir o real espaço da comunidade nas decisões. De forma a construir um novo tipo de relação que não exija que produtos locais se transformem em produtos industriais, sujeito à banalização para atender o turista, entendido apenas como um consumidor desenfreado de produtos. Conduzir o turista de mero consumidor a um conhecedor, capaz de promover a preservação.

Segue algumas linhas de ações sugeridas ao longo deste trabalho:

$\checkmark$ A informação como instrumento - desenvolvimento de projetos interpretativos do patrimônio cultural brasileiro. Abordagens transversais e busca de informação com órgãos competentes.

$\checkmark$ Avançar e romper práticas enraizadas no turismo brasileiro em busca da construção de políticas públicas integradas, desenvolvendo parcerias e unindo recursos principalmente entre o governo federal. Peças do mesmo dominó. Sair do discurso para a prática.

$\checkmark$ Efetivar as sugestões dadas pelo Ministério da Cultura de organização 
de Centros de Referência, onde se possa ter informação qualificada para o turista, transformando o turista consumidor em conhecedor, portanto, consciente da preservação ambiental e cultural.

$\checkmark$ Criar políticas que regulem essa relação entre turismo e patrimônio, com vistas à proteção do bem cultural e de sua permanência, inclusive dos seus usos e práticas.

$\checkmark$ Ampliar o espaço de participação da comunidade nas decisões e fortalecimento do Terceiro Setor e da Sociedade Civil Organizada.

$\checkmark$ Propor um desenvolvimento com uma ótica invertida que beneficie primeiramente a comunidade, desenvolvendo o turismo de vizinhança, entre as cidades vizinhas, os estados vizinhos, os países vizinhos, fortalecendo o turismo da América Latina. Invertendo a idéia de que o turismo acontece quando aparece o estrangeiro, principalmente o bem distante e de outras línguas.

O turismo para se desenvolver de forma correta há um longo caminho a percorrer, no entanto, positivamente se inicia um diálogo possível e legítimo, capaz de impulsionar a relação entre patrimônio imaterial e turismo como questões compatíveis se assim for planejado de forma cuidadosa e sustentável. 


\section{Referências Bibliográficas}

AMORIM, Lara Santos. O registro de manifestações culturais tradicionais. XXVIII Encontro da ANPOCS, 2004.

ANDRADE, Mário, O turista aprendiz. 2ª . Ed, São Paulo: Duas Cidades, 1983.

ARANTES, Antonio Augusto, O que é Cultura Popular, 14ª. ed., São Paulo: Brasiliense, 2004.

, O espaço da Diferença, Campinas, São Paulo:

Papirus, 2000.

, "Patrimônio Imaterial e referências culturais",

Rio de Janeiro, in Revista: Tempo Brasileiro nº 147, 2001.

ARENDT, Hannah, Entre o passado e o futuro, São Paulo: Perspectiva, 2000.

AUGÉ, Marc, Não-Lugares: Introdução a uma antropologia da supermodernidade, trad. Maria Lucia Pereira, Campinas, São Paulo: Papirus, 1994.

BOURDIEU, Pierre. Economia das trocas simbólicas. Série estudos, trad. Sergio Miceli. São Paulo: Perspectiva, 1998.

. O Poder Simbólico. $7^{\mathrm{a}}$. ed., trad. Fernando Tomaz. Rio de

Janeiro: Bertrand Brasil, 2004.

BARRETTO, Margarita. Turismo e Legado Cultural. São Paulo: Papirus, 2000. . In Turismo e Identidade local - uma visão

antropológica, Campinas, São Paulo: Papirus, 2003.

BALDUCCI, Álvaro Balducci, in Turismo e Identidade local - uma visão antropológica, Campinas, São Paulo: Papirus, 2003.

BAUMAM, Zygmunt, Modernidade Líquida. Trad. Plínio Dentzien. Rio de Janeiro: Zahar, 2001.

CANCLINI, Nestor Garcia. Culturas híbridas, São Paulo: Edusp, 1998. CORIOLANO, Luzia Neide M. T. (Org.) "Lazer e turismo em busca de uma sociedade sustentável", in: . Turismo com ética. Fortaleza: UECE, 1998.

CAVALCANTI, Maria Laura Cavalcanti. "Cultura e Saber do Povo: Uma nova perspectiva". Rio de Janeiro, in Revista: Tempo Brasileiro nº. 147, 2001.

DERRIDA, Jacques, Torres de Babel. Trad. Junia Barreto, Belo Horizonte: UFMG, 2002. 
DUMAZEDIER, Joffre. Lazer e Cultura Popular. Trad. Maria de Lourdes S. Machado, São Paulo: Perspectiva, 2000.

DURHAM, E. R. "A dinâmica cultural na sociedade moderna", in Ensaios de Opinião, Rio de Janeiro: Enubia, 1977.

ELIAS, Norbert. O processo civilizador. $2^{\mathrm{a}}$. Ed., Rio de Janeiro, Ed. Zahar, 1994.

FALCÃO, J. Patrimônio Imaterial: um sistema sustentável de proteção, Rio de Janeiro, in Revista: Tempo Brasileiro n. 147, 2001.

FEATHERSTONE, M. O Desmanche da cultura: globalização, pós-modernismo e identidade. São Paulo: Nobel/Sesc, 1997. , Cultura de Consumo e pós-modernidade. São Paulo: Nobel, 1998.

FERREIRA, AURÉLIO Buarque de Holanda. Novo dicionário da língua portuguesa. $3^{a}$. ed., Curitiba: Positivo, 2004.

GARCIA, MVC. De "O belo e o Velho" ao mosaico do intangível. Aspectos de uma poética e de algumas políticas de patrimônio. Dissertação de mestrado, DAN/UnB, 2004.

Del Rio, V., Duarte, C. e Maciel, T. Psicologia e projeto do ambiente construído. Rio de Janeiro: Seminário Internacional, Programação e resumos de trabalhos, UFRJ, 2000.

GIDDENS, Anthony. Modernidade e Identidade. Rio de Janeiro, Ed. Zahar, 2002.

KNAFOU, Remi. Turismo e Território: por uma abordagem científica do turismo. In: RODRIGUES, Adyr B. (org.), Turismo e Geografia: reflexões teóricas e enfoques regionais. São Paulo: Hucitec, 1996.

LARAIA, Roque de Barros. Cultura: um conceito antropológico. 15ª ed, Rio de Janeiro: Jorge Zahar Ed., 2002.

, "Patrimônio Imaterial: conceito e implicações", in

Patrimônio Imaterial, performance cultural e (re)tradicionalização. Brasília: ICSUNB, 2004.

LÉVI-STRAUSS, Laurent. "Patrimônio Imaterial e Diversidade Cultural: O novo decreto para a proteção dos bens imateriais". Rio de Janeiro, in Revista: Tempo Brasileiro n. 147, 2001.

LONDRES, Cecília. et al (org.). Patrimônio Imaterial, Rio de Janeiro, in Revista: Tempo Brasileiro n. 147, 2001. 
, Referências Culturais: base para novas políticas de patrimônio. Campinas, 1995.

Patrimônio e performance: uma relação interessante in

Patrimônio Imaterial, performance cultural e (re)tradicionalização. Brasília: ICSUNB, 2004.

MEDEIROS, Ana Elisabete de Almeida. "Imaterialidade criadora", in Patrimônio Imaterial, performance cultural e (re)tradicionalização. Brasília: ICS-UNB, 2004. MONNET, Jérôme. O álibe do patrimônio. In Revista do Patrimônio - 24 Cidadania, 1996, IPHAN/MinC.

MONTORO, Tânia Siqueira, et al (org). Cultura do Turismo, desafios e práticas socioambientais, Brasília: UNB, 2004.

ORTIZ, R. Mundialização e cultura, 2a ed. São Paulo: Brasiliense, 1994.

,Cultura Brasileira e Identidade Nacional, São Paulo: Brasiliense.

PEARCE, Douglas G. e BUTLER, Richard W., et al (org). Desenvolvimento em turismo - temas contemporâneos. São Paulo: Contexto, 2002.

SIQUEIRA, Deis, Turismo na Encruzilhada, Livro no prelo, Brasília, 2004.

SOUZA, Marina de Mello. "Patrimônio Imaterial, Turismo Cultural e Identidade Nacional: uma tentativa de refletir acerca de Parati", Rio de Janeiro, in Revista: Tempo Brasileiro n. 147, 2001.

SUASSUNA, Dulce M. F. de Almeida. "Uma incursão no universo da Cultura. $O$ caso das técnicas corporais", in Patrimônio Imaterial, performance cultural e (re)tradicionalização. Brasília: ICS-UNB, 2004.

TEIXEIRA, João Gabriel L.C., et al (org). Patrimônio Imaterial, performance cultural e (re)tradicionalização. Brasília: ICS-UNB, 2004.

URRY, John. O Olhar do turista. São Paulo, Studio Nobel, 2002.

VELOSO, Mariza. "Patrimônio Imaterial, memória coletiva e espaço público" in Patrimônio Imaterial, performance cultural e (re)tradicionalização. Brasília: ICSUNB, 2004.

YÚDICE, George, El Recurso de la Cultura, Barcelona, Gedisa, 2002. , A convivência da Cultura - Usos da cultura na era global. Trad. Marie-Anne Kremer, Belo Horizonte: UFMG, 2004.

ZERBINI, Ana Suely, A relação entre a estética imaginada e o uso de praças na cidade de Porto Alegre. Tese de Mestrado, Rio Grande do Sul: UFGRGS/PROPUR, 2005. 
Manuais e Programas:

Guia de desenvolvimento do turismo sustentável. Organização Mundial de Turismo - OMT, trad. Sandra Netz, Porto Alegre: Bookman, 2003.

Plano Nacional do Turismo - Diretrizes, Metas e Programas (2003-2007), $2^{\mathrm{a}}$. Edição - Ministério do Turismo, 2003

Programa Nacional do Patrimônio Imaterial - IPHAN, Ministério da Cultura, 2000. Acessado em maio/2005 em www.iphan.gov.br.

Registro do Patrimônio Imaterial. Dossiê final das atividades da Comissão e do grupo de Trabalho Patrimônio Imaterial. Ministério da Cultura. Instituto do Patrimônio Histórico e Artístico Cultural, 2003.

Sites consultados:

www.turismo.gov.br.

www.iphan.gov.br

www.cultura.gov.br

Artigos disponíveis pela internet:

Instituto Goiano de Pré-História e Antropologia (IGPA) - Universidade Católica de Goiás - "Memória, Identidade e Referências Culturais sobre o Núcleo Pioneiro de Goiânia". Acessado em maio/2005 em http://www.ucg.br/projetogoiania/Biblio.html

BARRETO, Túlio Velho. "As eleições de 2002 e seus significados". Acessado em março/2003 em www.fundaj.gov.br/observanordeste/obed003m.html

CAVALCANTI, Maria Laura Viveiros de Castro. "Cultura popular e sensibilidade romântica: as danças dramáticas de Mário de Andrade", REVISTA BRASILEIRA DE CIÊNCIAS SOCIAIS - VOL. 19 №. 54. Acessado em maio/2005 em www.anpocs.org.br/rbcs/rbcs54.htm

DIAS, Susana. Resenha do livro de Jacques Derrida: "A universidade sem condição". Acessado em Junho/2005 em www.comciencia.br/resenhas/2004/09/resenha1.htm

FILHO, João dos Santos. "Por que a ação da Embratur se torna preocupante para a formulação de Políticas Públicas internas em Turismo?" Revista Espaço Acadêmico, No. 48, Maio/2005. Acessado em maio/2005 em http://www.espacoacademico.com.br 
FILHO, João dos Santos. "Turismo brasileiro: equívocos, retrocessos e perspectivas - o balanço que nunca foi feito". Revista Espaço Acadêmico, №. 25, Junho/2003. Acessado em maio/2005 em http://www.espacoacademico.com.br

FILHO, João dos Santos. "Alguns comentários ao Plano Nacional do Turismo Diretrizes, Metas e Programas 2003-2007 - Um breve ensaio sociológico". Revista Espaço Acadêmico - No 27- Agosto/2003. Acessado em maio/2005 http://www.espacoacademico.com.br/027/27jsf.htm

MORAES, João Quartim. "As formas culturais, a arte e a técnica no horizonte do século XXI". Acessado em maio/2005 em www.sescsp.org.br/sesc/Conferencias

SANSOLO. Davis Gruber e CRUZ, Rita de Cássia Ariza. "Plano Nacional do Turismo: uma análise crítica". Acessado em fevereiro/2005 em www.ivtri.net/caderno/anteriores/10/

SEVERO, Fernanda. "Patrimônio histórico e artístico brasileiro e o turismo". Acessado em Junho/2005 em www.acontecendoaqui.com.br/artigos.php

TESCH, Moacir. Em entrevista para o Jornal Notícias FUNIBER - Fundación Universitaria Iberoamericana (FUNIBER). Acessado em Maio/2005 em http://www.funiber.org.br/noticias

TRIGO, Luciano. "O pensador sem fronteiras". Artigo do Jornal O Globo, seção Prosa \& Verso, de 14 de agosto de 2004. Acessado em Junho/2005 em http://www.estacaoliberdade.com.br/clip/globopapier.htm 
Anexo A

Decreto $n^{\circ} 3.551$ de 4 de agosto de 2000. 


\title{
DECRETO Nº 3.551 DE 4 DE AGOSTO DE 2000.
}

\author{
Institui o Registro de Bens Culturais de Natureza \\ Imaterial que constituem patrimônio cultural brasileiro, \\ cria o Programa Nacional do Patrimônio Imaterial e dá outras providências.
}

O PRESIDENTE DA REPÚBLICA, no uso das atribuições que lhe confere o art. 84, inciso IV, e tendo em vista o disposto no art. 14 da Lei $\mathrm{n}^{\circ}$ 9.649, de 27 de maio de 1998, DECRETA:

Art. $1^{\circ}$ Fica instituído o registro de bens culturais de natureza imaterial que constituem patrimônio cultural brasileiro.

$\int 1^{\circ}$ Esse registro se fará em um dos seguintes livros:

I - Livro de Registro dos Saberes, onde serão inscritos conhecimentos e modos de fazer enraizados no cotidiano das comunidades;

II - Livro de Registro das Celebrações, onde serão inscritos rituais e festas que marcam a vivência coletiva do trabalho, da religiosidade, do entretenimento e de outras práticas da vida social;

III - Livro de Registro das Formas de Expressão, onde serão inscritas manifestações literárias, musicais, plásticas, cênicas e lúdicas;

IV - Livro de Registro dos Lugares, onde serão inscritos mercados, feiras, santuários, praças e demais espaços onde se concentram e reproduzem práticas culturais coletivas.

$\int 2^{\circ} \mathrm{A}$ inscrição num dos livros de registro terá sempre como referência a continuidade histórica do bem e sua relevância nacional para a memória, a identidade e a formação da sociedade brasileira.

$\int 3^{\circ}$ Outros livros de registro poderão ser abertos para a inscrição de bens culturais de natureza imaterial que constituam patrimônio cultural brasileiro e não se enquadrem nos livros definidos no parágrafo primeiro deste artigo.

Art. $2^{\circ}$ São partes legítimas para provocar a instauração do processo de registro:

I - o Ministro de Estado da Cultura;

II - instituições vinculadas ao Ministério da Cultura;

III - Secretarias de Estado, de Município e do Distrito Federal;

IV - sociedades ou associações civis.

Art. $3^{\circ}$ As propostas para registro, acompanhadas de sua documentação técnica,

serão dirigidas ao Presidente do Instituto do Patrimônio Histórico e Artístico Nacional IPHAN, que as submeterá ao Conselho Consultivo do Patrimônio Cultural.

$\int 1^{\circ} \mathrm{A}$ instrução dos processos de registro será supervisionada pelo IPHAN.

$\int 2^{\circ}$ A instrução constará de descrição pormenorizada do bem a ser registrado, acompanhada da documentação correspondente, e deverá mencionar todos os elementos que lhe sejam culturalmente relevantes.

$\int 3^{\circ} \mathrm{A}$ instrução dos processos poderá ser feita por outros órgãos do Ministério da Cultura, pelas unidades do IPHAN ou por entidade, pública ou privada, que detenha conhecimentos específicos sobre a matéria, nos termos do regulamento a ser expedido pelo Conselho Consultivo do Patrimônio Cultural.

$\int 4^{\circ}$ Ultimada a instrução, o IPHAN emitirá parecer acerca da proposta de registro e enviará o processo ao Conselho Consultivo do Patrimônio Cultural, para deliberação.

$\int 5^{\circ} \mathrm{O}$ parecer de que trata o parágrafo anterior será publicado no Diário Oficial da União, para eventuais manifestações sobre o registro, que deverão ser apresentadas ao Conselho Consultivo do Patrimônio Cultural no prazo de até trinta dias, contados da data de publicação do parecer.

Art. $4^{\circ} \mathrm{O}$ processo de registro, já instruído com as eventuais manifestações apresentadas, será levado à decisão do Conselho Consultivo do Patrimônio Cultural. 
Art. $5^{\circ}$ Em caso de decisão favorável do Conselho Consultivo do Patrimônio Cultural, o bem será inscrito no livro correspondente e receberá o título de "Patrimônio Cultural do Brasil".

Parágrafo único. Caberá ao Conselho Consultivo do Patrimônio Cultural determinar a abertura, quando for o caso, de novo Livro de Registro, em atendimento ao disposto nos termos do $\int 3^{\circ}$ do art. $1^{\circ}$ deste Decreto.

Art. $6^{\circ}$ Ao Ministério da Cultura cabe assegurar ao bem registrado:

I - documentação por todos os meios técnicos admitidos, cabendo ao IPHAN manter banco de dados com o material produzido durante a instrução do processo.

II - ampla divulgação e promoção.

Art. $7^{\circ}$ O IPHAN fará a reavaliação dos bens culturais registrados, pelo menos a

cada dez anos, e a encaminhará ao Conselho Consultivo do Patrimônio Cultural para decidir sobre a revalidação do título de "Patrimônio Cultural do Brasil".

Parágrafo único. Negada a revalidação, será mantido apenas o registro, como referência cultural de seu tempo.

Art. $8^{\circ}$ Fica instituído, no âmbito do Ministério da Cultura, o "Programa Nacional

do Patrimônio Imaterial", visando à implementação de política específica de inventário, referenciamento e valorização desse patrimônio.

Parágrafo único. O Ministério da Cultura estabelecerá, no prazo de noventa dias, as bases para o desenvolvimento do Programa de que trata este artigo.

Art. $9^{\circ}$ Este Decreto entra em vigor na data de sua publicação.

Brasília, 4 de agosto de 2000; $179^{\circ}$ da Independência e $112^{\circ}$ da República.

FERNANDO HENRIQUE CARDOSO

FRANCISCO WEFFORT 
Anexo B

Plano Nacional do Turismo - Diretrizes, Metas e Programas (PNT: 2003-2007),

$2^{\mathrm{a}}$. Edição - Ministério do Turismo, 2003. 


\title{
PLANO NACIONAL DO TURISMO Diretrizes, Metas e Programas
}

\author{
$2003-2007$
}

Brasilia, 29 de abril de 2003. 
Ministério do Turismo

\section{PLANO NACIONAL DO TURISMO}

\section{DIRETRIZES, METAS EPROGRAMAS}

1. Mensagem do Senhor Presidente da República

2. Mensagem do Senhor Ministro do Turismo

3. Gestão do Turismo

4. Estruturação do Plano Nacional do Turismo

a) Apresentação

b) Diagnóstico

c) Principios Orientadores para o Desenvolvimento do Turismo

- Vetores de Governo

- Pressupostos

d) Visão

e) Objetivos Gerais e Objetivos Especificos

5. Metas para o Turismo-2003-2007

6. Macro-Programas

7. Entidades que contribuíram com propostas para elaboração do texto básico do Plano Nacional do Turismo

8. Documentos consultados 


\section{Mensagem doSenhor Presidente da República}

Muito tem-se falado dos desafios colocados ao novo governo no campo do desenvolvimento econômico e da área social.

A necessidade de criar empregos, gerar divisas para $\circ$ pais, de reduzir as desigualdades regionais e distribuir melhor a renda são questões que devem ser enfrentadas de imediato.

O Brasil indubitavelmente é um lugar único pela sua riqueza natural, cultural, econômica e histórica. Isto faz de nosso pais um espaço maravilhoso com inúmeros atrativos turísticos, tendo na diversidade nosso instrumento principal de sua potencialização

É inegável a nossa vocação para o turismo. Dispomos de todas as condições para cativar nossos visitantes - praias, florestas, montanhas, rios, festivais, culinária diferenciada, parques nacionais, cidades históricas e a tradicional hospitalidade brasileira, assim como, os equipamentos, as empresas, e a qualidade dos serviços já encontrados em muitas regiōes do pais.

Receber bem é o traço marcante do nosso povo. A mistura de nossas raças gerou uma gente alegre, solidária, onde todos se encontram nas diferenças, num ambiente de convivência pacifica. Somos um país de todos.

Por outro lado, o crescimento de nossa economia aliado a posição estratégica do país no continente americano torna-nos um ponto nodal de atração de eventos técnicos, comerciais ou associativos que articulados com as ofertas de lazer caracterizam o Brasil 
como um país especial em oferecer múltiplas possibilidades de viagens. Os eventos são conquistas onde o dever é de todos. Nesse sentido conclamo os brasileiros a adotarem o lema " Nosso Próximo Evento é no Brasil".

A vocação natural do nosso pais deve ser transformada em fonte permanente de riqueza, através do turismo.

O turismo, pela natureza de suas atividades e pela dinâmica de crescimento dos últimos dez anos é o segmento da economia que pode atender de fo rma mais completa e de maneira mais rápida os desafios colocados. Especialmente se for levada em conta a capacidade que o Turismo tem de interferir nas desigualdades regionais, amenizandoas , visto que, destinos turísticos importantes no Brasil estão localizados em regiöes mais pobres, e, pelas vias do Turismo, passam a ser visitadas por cidadãos que vêm dos centros mais ricos do pais e do mundo.

O turismo quando bem planejado, dentro de um modelo adequado, onde as comunidades participam do processo, possibilita a inclusão dos mais variados agentes sociais. Os recursos gerados pelo turista circulam a partir dos gastos praticados nos hotéis, nos restaurantes, nos bares, nas áreas de diversões e entretenimento. Todo comércio local é beneficiado.

Jornaleiros, taxistas, camareiras, cozinheiras, artesãos, músicos, barqueiros, pescadores e outros profissionais, passam a ser agentes do processo de desenvolvimento. $\mathrm{O}$ envolvimento abrange toda a comunidade receptiva.

Neste modelo, a grande maioria do setor é constituído de pequenas e médias empresas, fazendo com que o desenvolvimento da atividade possa naturalmente contribuir como fator de distribuição de renda. 
A criação de postos de trabalho no setor de turismo exige investimentos de menor vulto se comparados com outros setores da atividade econômica; ao mesmo tempo a agilidade com que se processa a qualificação dos recursos humanos, a impossibilidade da substituição da prestação de serviços por máquina e equipamentos, faz do turismo um setor fundamental para o cumprimento das metas estabelecidas pelo governo.

A geração de novos empregos no Brasil transitará via a promoção de investimentos no setor turístico. Ciente destas necessidades o Governo Federal vem cumprindo o seu papel de buscar maior transversalidade entre o Ministério do Turismo e outros órgãos afim de proporcionar as ferramentas necessárias para cumprir suas metas. Entendendo a importância do turismo como atividade estratégica de autosustentabilidade, com efeitos sociais evidentes os ministérios do Turismo, Trabalho e Emprego e da Integração Nacional em parceria com o Banco do Brasil e a Caixa Econômica Federal estão colaborando com recursos no montante de $\mathrm{R} \$ 1,4$ bilhăo para serem investidos no setor turístico nos próximos doze meses. Estas novas linhas de financiamento objetivam uma maior democratização do crédito no Brasil, induzindo e incentivando investimentos de pequeno e micro empreendedores e ajudando a desonerar o lazer do trabalhador.

Além dessas perspectivas, o turismo pode cumprir um papel importante no equilibrio da balança comercial, com o ingresso de novas divisas, por meio do aumento no fluxo de turistas estrangeiros e da atração de investimentos para a construção de equipamentos turísticos.

Por todos esses motivos, já em campanha haviamos assumido o compromisso de criarmos o Ministério do Turismo e de profissionalizarmos a EMBRATUR, voltando o seu foco para a promoção, marketing e o apoio a comercialização do produto turístico brasileiro no mundo. 
A concretização deste compromisso coloca o setor como uma das grandes prioridades do governo, estando integrado à macro estratégia do país e cumprindo papel fundamental no desenvolvimento econômico e na redução das desigualdades sociais.

Dentro desta nova realidade estrutural a proposta do Plano Nacional do Turismo vem consolidar o Ministério como articulador do processo de integração dos mais diversos segmentos do setor turístico.

O Plano Nacional deve ser o elo entre os governos federal, estadual e municipal; as entidades năo govemamentais; a iniciativa privada e a sociedade no seu todo. Deve ser fator de integração de objetivos, otimização de recursos e junção de esforços para incrementar a qualidade e a competitividade, aumentando a oferta de produtos brasileiros nos mercados nacional e internacional.

Estamos apresentando uma proposta de construção coletiva de um plano com uma visão compartilhada. A perseverança na busca da unidade na nossa diversidade será constante. Estamos convencidos de que essa atividade está destinada a constituirse em fator decisivo para ampliação de oportunidades e para utilização sustentável de nossos recursos naturais e culturais, proporcionando um desenvolvimento conseqüente e equilibrado em todo território nacional. 


\section{MENSAgem do SENHOR MINISTRO do TURISMO}

A apresentação à sociedade do Plano Nacional do Turismo reforça o compromisso assumido pelo $\mathrm{Sr}$. Presidente da República quando da criaçăo do Ministério, de priorizar o turismo como elemento propulsor do desenvolvimento sócioeconômico do país.

O Plano Nacional foi concebido de forma coletiva, com uma ampla consulta às mais diversas regiões brasileiras e a todos os setores representativos do turismo e constitui-se em um processo dinâmico de construção permanente. Traduz uma concepção de desenvolvimento que, além do crescimento, busca a desconcentração de renda por meio da regionalização, interiorização e segmentação da atividade turistica.

Estamos propondo um novo modelo de gestão descentralizada com a reformulação do Conselho Nacional do Turismo e dos Fóruns Estaduais que estabelecerão permanente comunicação com as necessidades advindas das regiōes, municípios e destinos turísticos.

Ressaltamos a importância da inovação na forma e no conteúdo das relações e interações de toda a cadeia produtiva. Entendemos que estas interações devem se pautar em uma visão sistêmica e cooperada entre os diversos atores no que resultará em maior competitividade empresarial e proporcionará maior inclusão social.

Para tanto é necessário inovar na condução das políticas públicas, romper as inércias e os empecilhos que têm limitado o potencial desta atividade como agente de transformaçōes e como fonte verdadeira de riqueza econômica e desenvolvimento social. Ao colocar o Plano Nacional em execução, permitimo-nos reorientar esforços e eliminar obstáculos de tal forma que se realize o nosso compromisso de fazer do turismo 
uma prioridade nacional. Assim sendo, temos que preparar o futuro, olhar para frente e construir o que deverá ser esta atividade nos anos vindouros, com base em um pensamento estratégico, a partir do reconhecimento do turismo como atividade econômica relevante que requer planejamento, análise, pesquisa e informações consistentes.

Devemos diversificar nossos mercados assim como os produtos e destinos que oferecemos. O governo federal, os governos estaduais e municipais, instituiçōes e associações de classe, universidades, empresários, trabalhadores, organizações não governamentais e todos os demais que compöem o setor devem realizar um esforço para incrementar a qualidade e a competitividade do turismo brasileiro, neste momento em que muitos outros países estão competindo para conquistar mercados turísticos.

Destacamos ainda a atenção que devemos dirigir ao incremento do turismo interno, que deve ser fortalecido pelo consumo da sociedade brasileira, permitindo a todos o acesso ao lazer e às férias, respondendo a uma aspiração legitima dos nossos cidadãos e tendo no turismo um fator de construção da cidadania e de integração social.

Desta forma, estamos apresentando à sociedade brasileira o Plano Nacional do Turismo, cuja construção, consolidação e execução deverão ocorrer ao longo dos próximos anos, tendo presente que o turismo:

- deverá se transformar em fonte geradora de novos empregos e ocupações, proporcionando uma melhor distribuiçăo de renda e melhorando a qualidade de vida das comunidades;

- ao contribuir para multiplicar os postos de trabalho no território nacional poderá interferir positivamente no âmbito da violência urbana, fortalecendo a segurança da população; 
- deverá transformar-se em um agente da valorização e conservação do patrimônio ambiental (cultural e natural), fortalecendo o princípio da sustentabilidade;

- tornar-se-á um instrumento de organização e valorização da sociedade, articulando seus interesses econômicos, técnicos, cientificos e sociais, com o lazer, a realização de eventos, feiras e outras atividades afins;

- poderá, por meio de programas de qualificação profissional, elevar a qualidade da oferta turistica nacional, fator essencial para inserir o pais competitivamente no mercado internacional;

- atuará como mecanismo instigador de processos criativos, resultando na geração de novos produtos turísticos apoiados na regionalidade, genuinidade e identidade cultural do povo brasileiro, fortalecendo a autoestima nacional e a de nossas comunidades;

- a partir das novas politicas sociais, poderá configurar-se como uma das mais eficazes expressőes do uso do tempo liberado do trabalhador, contribuindo para a sua saúde física e mental;

- ao ser fortalecido internamente pelo exercício contínuo e sistêmico de consumo pela sociedade brasileira, deverá criar as condições desejáveis para a estruturação de uma oferta turística qualificada capaz de atender melhor o mercado internacional; 
Ministério do Turismo

- para alcançar as metas desejáveis no balanço de pagamentos, exigirá normatização e legislação adequadas com vistas à facilitação e o aumento da entrada de turistas estrangeiros:

- por sua dinâmica, necessita de uma constante troca de informaçōes entre os destinos turísticos, a oferta, e os mercados consumidores, o que requer investimentos constantes em marketing.

Por fim, é importante salientar que as metas desafiadoras para o período 20032007 requerem entusiasmo e determinação, cujo atingimento somente será possivel por meio de um esforço conjunto entre agentes públicos e privados para solidificar uma estrutura turística integrada e duradoura, baseada na força das Parcerias e na Gestão Descentralizada. 


\section{GESTÃO DOTURISMO}

A criação do Ministério do Turismo atende diretamente a uma antiga reivindicação do setor turístico. O Ministério, como órgão da administraçăo direta, terá as condiçōes necessárias para articular com os demais Ministérios, com os governos estaduais e municipais, com o poder legislativo, com o setor empresarial e a sociedade organizada, integrando as políticas públicas e o setor privado. Desta forma o Ministério cumprirá com determinação um papel aglutinador, maximizando resultados e racionalizando gastos.

A estrutura do Ministério é composta por órgãos de assistência direta e imediata ao Ministro, além dos seguintes órgãos finalisticos:

a) Secretaria de Politicas de Turismo: compete precipuamente " a formulação, elaboração avaliação e monitoramento da Política Nacional do Turismo, de acordo com as diretrizes propostas pelo Conselho Nacional do Turismo", bem como articular as relações institucionais e internacionais necessárias para a condução desta Politica.

b) Secretaria de Programas de Desenvolvimento do Turismo: compete realizar açōes de estimulo às iniciativas públicas e privadas de incentivos, de fomento, de promoção de investimentos em articulação com os Programas Regionais de Desenvolvimento, bem como apoiar e promover a produção e comercialização de produtos associados ao turismo e a qualificação dos serviços.

c) Instituto Brasileiro de Turismo - EMBRATUR: Autarquia que tem como área de competência a promoção, divulgação e o apoio à comercialização dos produtos, serviços e destinos turísticos do país no exterior. 
d) Conselho Nacional do Turismo: órgão colegiado de assessoramento, diretamente vinculado ao Ministro do Turismo que tem como atribuições " propor diretrizes e oferecer subsídios técnicos para a formulação e acompanhamento da Política Nacional do Turismo". Esse Conselho é formado por representantes de outros Ministérios e Instituições Públicas que se relacionam com o turismo e das entidades de caráter nacional, representativas dos segmentos turísticos.

O Ministério tem como desafio œnceber um novo modelo de gestão pública, descentralizada e participativa, atingindo em última instância o município, onde efetivamente o turismo acontece.

Desta forma estamos propondo um sistema de gestão composto no seu nivel estratégico (união), o Ministério, o Conselho Nacional de Turismo e o Fórum Nacional de Secretários e Dirigentes Estaduais de Turismo.

O Fórum Nacional de Secretários é um órgão informal, consultivo, constituído pelos Secretários e Dirigentes Estaduais de Turismo, que auxiliará no apontamento de problemas e soluçōes, concentrando as demandas oriundas dos Estados e Municípios.

Desta forma o núcleo estratégico estabelecerá canais de interlocução com os Estados da Federação, que por sua vez estarão conectados às necessidades advindas dos Municípios e regiões turisticas, tendo como atribuições :

- contribuir para construção das politicas e do Plano Nacional do Turismo, atuando como fórum facilitador e articulador para a formação das parcerias necessárias;

- elaborar os programas, projetos e açöes estratégicas, aportando recursos e capacidade gerencial, co-responsabilizando-se para a construção de uma nova realidade; 
- criar as parcerias e articular com os diversos atores, para executar e avaliar os programas e projetos concebid os:

Outro instrumento do processo de descentralização será a constituição de 27 fóruns estaduais com a finalidade de integrar a cadeia produtiva nos Estados e Distrito Federal, facilitando a implantação do Plano Nacional do Turismo.

O Fórum Estadual será composto pelo Secretário ou Dirigente Estadual, de um representante designado pelo Ministério do Turismo, pelas entidades públicas e privadas participantes do Conselho Nacional, por intermédio de suas representações regionais, pela representação dos Municípios, pelas Instituições de Ensino Superior/Turismo, e demais entidades de relevância estadual vinculadas ao turismo.

O Fórum estadual terá como atribuiçăo o cumprimento de um papel fundamental para a operacionalização das politicas formuladas pelo núcleo estratégico, constituindo-se em um canal de ligação entre o Governo Federal e os destinos turisticos.

Ainda como parte da política de descentralizaçăo, os Municipios serão incentivados a criar os Conselhos Municipais de Turismo e organizarem-se em consórcios para formar Roteiros Integrados, ofertando um conjunto de produtos turisticos, completando-se assim o sistema de gestão do turismo brasileiro.

Apresentando a seguir o diagrama das relações entre os diversos atores que compõe o sistema de Gestão: 


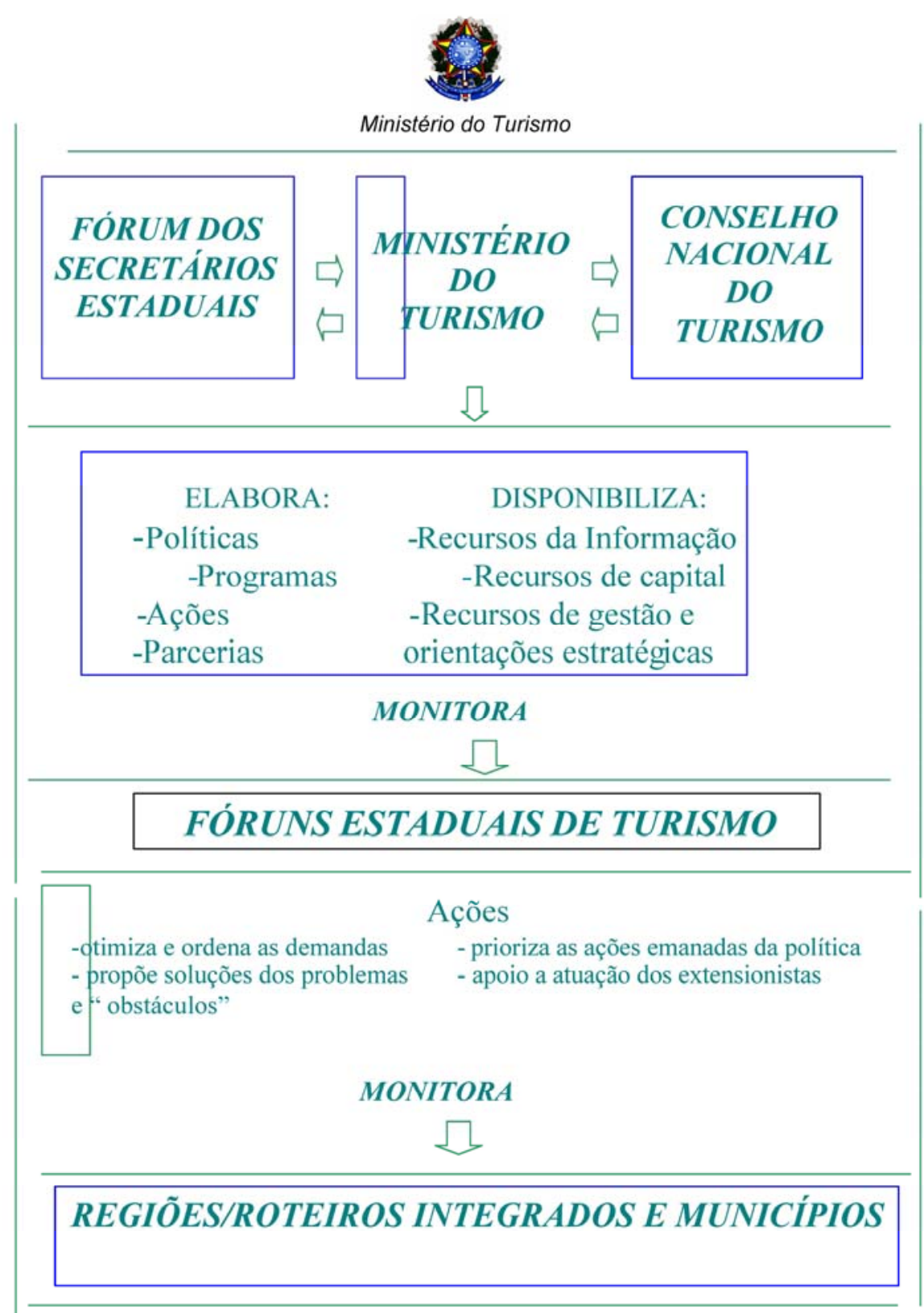




\section{ESTRUTURAÇÃO do PLANO NACIONAL DO TURISMO}

\section{a) Apresentação}

O Plano Nacional do Turismo é o instrumento de planejamento do Ministério do Turismo que tem como finalidade explicitar o pensamento do governo e do setor produtivo e orientar as ações necessárias para consolidar o desenvolvimento do setor do Turismo.

Este documento está sendo elaborado de forma participativa dentro de um processo permanente de discussão e atualizaçăo, de acordo com ๘ necessidades inerentes à dinâmica do setor.

Iniciamos o processo de construção do Plano com duas reuniões coordenadas pelo Ministro do Turismo, onde explicitamos nossas idéias iniciais e solicitamos o envio das sugestões e apontamento dos principais problemas, buscando obter um amplo espectro de opiniões sobre as dificuldades do turismo no Brasil e as alternativas de solução destes problemas.

A primeira reunião contou com a participação de todas as entidades, instituiçōes e empresas de porte nacional e representativas no segmento turistico. A segunda reunião contou com a presença dos secretários e dirigentes estaduais de turismo e presidentes de empresas públicas de turismo. Após ouvirmos todas as entidades individualmente ou em grupos afins.

Esta ação inicial resultou num enorme volume de contribuições que foram sistematizadas e agrupadas em eixos temáticos de interesse, sobre os quais assentamos inicialmente o Plano Nacional do Turismo. 
A análise destas sugestões nos permitiu ampliar o entendimento dos grandes desafios a enfrentar e a consolidar uma proposta inicial para o turismo brasileiro contendo:

- Sistema de Gestão.

- Visão de futuro.

- Os objetivos que devemos perseguir.

- As metas que necessitamos alcançar.

- Os eixos estruturantes do turismo.

Apresentamos a proposta inicial do Plano nas diferentes regiōes brasileiras. As reuniōes ocorreram em Belém, com representantes da região norte; em João Pessoa, com representantes dos estados nordestinos; em Săo Paulo, com representantes do sudeste; em Curitiba, com os estados do sul, e em Brasília com o centro-oeste.

A presença e participação maciça de dirigentes estaduais de turismo, de entidades não governamentais e representantes do setor privado referendou a proposta inicial do Plano.

O Plano foi ainda apresentado nesta fase ao conjunto de dirigentes de turismo, reunidos em Natal, no Fórum Nacional de Secretários Estaduais de Turismo. A partir destas reuniōes organizamos o Plano em 7 macro-programas estratégicos que serăo desdobrados em programas.

Iniciamos uma segunda rodada de reuniōes com 34 instituiçōes representativas do turismo, no âmbito nacional, para apresentar os macro-programas e a dinâmica de construção dos programas. Esses programas serão concebidos em parceria com o Conselho Nacional do Turismo por intermédio de suas Câmaras Temáticas, que por sua vez, se constituem em um espaço de debates e contribuições que conduzirá à solução dos problemas apontados. 


\section{b) Diagnóstico}

O Brasil, apesar dos avanços obtidos nos últimos anos, está longe de ocupar um lugar no cenário turístico mundial compativel com suas potencialidades e vocações. A falta de articulaçōes entre os setores governamentais tem gerado politicas desencontradas, fazendo com que os parcos recursos destinados ao setor se percam em açőes que se sobrepőem ou que não estão direcionados para objetivos comuns. $\mathrm{A}$ falta de articulação também se faz presente entre os setores público e privado, agravando os problemas descritos a seguir:

- $\quad$ ausência de um processo de avaliação de resultados das políticas e planos destinados ao setor,

- insuficiência de dados, informações e pesquisas sobre o turismo brasileiro,

- qualificaçăo profissional deficiente dos recursos humanos do setor, tanto no âmbito gerencial quanto nas habilidades especificas operacionais,

- inexistência de um processo de estruturação da cadeia produtiva impactando a qualidade e a competitividade do produto turístico brasileiro,

- regulamentação inadequada da atividade e baixo controle de qualidade na prestaçăo de serviços com foco na defesa do consumidor,

- superposição dos dispositivos legais nas várias esferas públicas, requerendo uma revisão de toda legislação pertinente ao setor,

- oferta de crédito insuficiente e inadequada para o setor turístico, 
Ministério do Turismo

- deficiência crônica na gestão e operacionalização de toda infra-estrutura básica (saneamento, água, energia, transportes) e turistica,

- baixa qualidade e pouca diversidade de produtos turísticos ofertados nos mercados nacional e internacional,

- insuficiência de recursos e falta de estratégia e articulação na promoção e comercialização do produto turístico brasileiro.

A criação do Ministério do Turismo, o direcionamento da Embratur para a promoção e apoio à comercialização, a elaboração do Plano Nacional do Turismo com ampla participação da sociedade, são sinais claros de que o turismo é uma das grandes prioridades desse governo e que os problemas acima apontados serão verdadeiramente enfrentados. 


\section{c) Princípios orientadores para o Desenvolvimento do Turismo}

A importância do Turismo no processo de desenvolvimento de um país não depende somente da existência dos recursos naturais e culturais transformados em Produtos Turísticos.

Devemos incorporar um conjunto de fatores estruturantes que elevem o nivel de atratividade e competitividade dos nossos Produtos de maneira a garantir o crescimento dos fluxos turisticos.

A multidisciplinariedade do setor, os impactos econômicos, sociais, ambientais, políticos e culturais gerados pelo Turismo exigem um processo de Planejamento e Gestão que orientem, discipline e se constitua em um poderoso instrumento de aceleração do desenvolvimento nos niveis municipal, regional e nacional.

Buscamos, por intermédio do Turismo, contribuir para o desenvolvimento do país gerando um amplo processo de mudanças que envolvem o cidadão, o estado e o setor produtivo.

Desejamos um novo modelo para o Turismo que contemple e harmonize a força e o crescimento do mercado com a distribuição da riqueza.

Isto pressupõe a integração de soluções nos campos econômico-social, politico e ambiental.

O aumento da competitividade do setor, o seu impacto na melhoria das condiçōes de vida da população, a descentralização das decisões e o respeito ao meio ambiente, são pilares para a construção de um novo padrão de desenvolvimento, no qual todas as regiōes possam crescer de forma integrada. 
Com o Turismo poderemos desconcentrar o crescimento econômico, reduzir desigualdades e criar novas oportunidades para a construção de um Brasil melhor, guiados por principios universais da ética.

Uma vez que estes princípios se aplicam a todos os individuos, comunidades e sociedades, eles devem transparecer durante o desempenho especifico das atividades de todos os agentes do turismo.

O comportamento e a prática do turismo devem ser pautados por padrōes éticos concretos e obedecer os principios gerais contidos no Código Mundial da Ética no Turismo - Organização Mundial do Turismo - 2000.

Desta forma podemos afirmar que todos os Programas, Projetos e Ações do Plano Nacional do Turismo terão como pressupostos básicos a ética e a sustentabilidade e como princípios orientadores os seguintes vetores de governo:

\section{Vetores de Governo}

REDUÇÃO DAS DESIGUALDADES REGIONAIS E SOCIAIS GERAÇÃO E DISTRIBUIÇÃO DE RENDA GERAÇÃO DE EMPREGO E OCUPAÇÃO

EQUILIBRIO DO BALANÇO DE PAGAMENTOS 
Ministério do Turismo

\section{d) Visão}

O turismo no Brasil contemplará as diversidades regionais, configurando-se pela geração de produtos marcados pela brasilidade, proporcionando a expansão do mercado interno e a inserção efetiva do País no cenário turístico mundial. A geração do emprego, ocupação e renda, a redução das desigualdades sociais e regionais, e o equilibrio do balanço de pagamentos sinalizam o horizonte a ser alcançado pelas ações estratégicas indicadas. 
Ministério do Turismo

e) Objetivos Gerais e Objetivos Especificos

O Plano Nacional do Turismo está estruturado a partir dos seus objetivos à partir dos quais derivam os Macro Programas, Programas e Açőes.

Cada um desses objetivos que perseguimos, representa uma área espec ífica que sugere na sua essência os resultados que desejamos atingir, a saber :

\section{e.1) Objetivos Gerais}

- Desenvolver o produto turístico brasileiro com qualidade, contemplando nossas diversidade regionais, culturais e naturais.

- Estimular e facilitar o consumo do produto turístico brasileiro nos mercados nacional e internacional.

\section{e.2) Objetivos Especificos}

- Dar qualidade ao produto turístico.

- Diversificar a oferta turística.

- Estruturar os destinos turísticos.

- Ampliar e qualificar o mercado de trabalho

- Aumentar a inserção competitiva do produto turístico no mercado internacional.

- Ampliar o consumo do produto turístico no mercado nacional.

- Aumentar a taxa de permanência e gasto médio do turista 


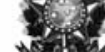

Ministério do Turismo

\section{METAS PARA O TURISMO-2003- 2007}

\section{1 - Criar condiçöes para gerar 1.200 .000 novos empregos e ocupaçōes}

5.2 - Aumentar para 9 milhões o número de turistas estrangeiros no Brasil

5.3 - Gerar 8 bilhões de dólares em divisas

5.4 - Aumentar para 65 milhões a chegada de passageiros nos vôos domésticos

5.5 - Ampliar a oferta turistica brasileira, desenvolvendo no mínimo três produtos de qualidade em cada Estado da Federação e Distrito Federal 
Ministério do Turismo

5.1 - Criar condições para gerar 1.200.000 novos empregos e ocupações no turismo

O problema do desemprego é um dos maiores desafios a serem enfrentados pelo Governo Federal. O baixo desempenho da economia brasileira dos últimos anos, agravou este problema em nosso país.

Observamos, ao longo dos últimos anos, que o turismo foi um dos setores que mais colaborou com a geração de novos empregos e para o reaproveitamento da mãode-obra de outros setores.

Segundo a Organização Mundial de Turismo, o turismo é responsável por 1 em cada 9 empregos gerados no mundo.

Para atingir a meta desejada, implementaremos açōes prioritárias dentro do plano, quais sejam: a oferta de crédito aos empreendedores do turismo e açöes de captação de investimentos, no Brasil e no Exterior, para novos empreendimentos turísticos. O resultado deste trabalho deve gerar investimentos na economia de aproximadamente 12 bilhões de reais até 2007 . 
Ministério do Turismo

5.2 - Aumentar para 9 milhões o número de turistas estrangeiros no Brasil

Após 7 anos de crescimento contínuo, o número de turistas estrangeiros no Brasil caiu consideravelmente nos 2 últimos anos.

A crise econômica mundial, em especial a crise Argentina, o baixo crescimento do Brasil e os atentados de 11 de setembro, contribuíram para que tivéssemos em 2002 apenas 3,8 milhões de turistas visitando o Brasil, o pior resultado dos últimos 5 anos

Atingir a meta desejada é um enorme desafio, que vai exigir uma promoção diferenciada para o mercado internacional, de maneira contínua, difundindo uma nova imagem de país moderno, com credibilidade e com produtos de qualidade, que, além de propiciar o turismo de lazer aos visitantes, deve oferecer oportunidades de negócios, eventos e incentivo.

Temos que integrar à esta imagem a essência brasileira, sua cultura, sua diversidade étnica, social e as diferentes regiőes do país.

Vamos definir com clareza nossos mercados alvos, priorizando os mercados sul americanos de curta distância e os de longa distância com afinidade cultural com o Brasil.

Para podermos crescer significativamente é necessário dispormos de algumas condições fundamentais. 
Ministério do Turismo

Devemos estimular as articulações entre agentes públicos e privados para realizar ações consistentes de promoção, disponibilizarmos recursos e ainda desenvolver os canais de comercialização.

Desta forma alcançaremos taxas de crescimento acima de $15 \%$ ao ano, atingindo 9 milhões de turistas em 2007.

Ressaltamos que esta meta parte de condições ótimas de mercado e de infra-estrutura necessária de receptivo. Em uma conjuntura que chamariamos de boa nossos estudos indicam, aplicado este Plano, a possibilidade de chegada de 7,5 milhōes de turistas estrangeiros em 2007. 


\section{3 - Gerar 8 bilhões de dólares em divisas}

Após 7 anos de crescimento na receita cambial gerada pelo turismo no Brasil, registramos nos 2 últimos anos uma curva de decréscimo, acompanhando a queda no fluxo de turistas estrangeiros.

A crise econômica mundial, fez com que encerrássemos o ano de 2002, com 3,8 milhōes de turistas, gerando uma receita de 3,12 bilhões de dólares.

Atingir a meta desejada vai depender não só do aumento do fluxo de turistas, estimado em 9 milhöes até 2007, mas de outras variáveis, como o tempo de permanência e o aumento do gasto médio per capita do turista.

Precisamos aumentar, ainda os 12,2 dias de permanência média e os US $\$ 81,21$ de gasto médio per capita registrado em 2001.

A mudança do foco da promoção, contemplando a diversidade cultural e regional brasileira, o incremento à comercialização de novos produtos de lazer, negócios, eventos e incentivos; vão proporcionar ao visitante estrangeiro um leque ampliado de opçöes. O fortalecimento destes segmentos cria as condições para o aumento do tempo de permanência do turista no Brasil.

A disponibilização para o consumo de um número maior de serviços turísticos qualificados, o incremento da produção artesanal, o produto típico com a marca brasileira 
Ministério do Turismo

e a integração destes produtos com o turismo, são ações que se somam para atingirmos os 8 bilhões de divisas desejados.

Ressaltamos que esta meta está relacionada com as condiçōes ótimas de entrada de 9 milhöes de turistas estrangeiros. Para uma conjuntura boa estamos projetando gerar US\$7,1 bilhões em divisas até o ano de 2007. 


\section{4 - Aumentar para 65 milhões a chegada de passageiros nos} vôos domésticos

O número de desembarques nacionais de passageiros vem crescendo continuamente nos últimos 7 anos.

Este crescimento se acentuou nos últimos 2 anos em função da alta do dólar, que fez com que uma maior quantidade de brasileiros, optasse por viajar pelo Brasil em detrimento de outros des tinos internacionais.

Ao final de 2001 atingimos 32,6 milhöes de desembarques, com incremento de $14,3 \%$ em relação ao ano anterior.

Mesmo que se mantenha a atual relaçőes cambial, dólar / real, novas açōes se fazem necessárias para atingirmos a meta desejada.

Destacamos abaixo os principais eixos de intervenção:

- oferta de novos produtos, contemplando nossa diversidade cultural e regional;

- fortalecimento dos segmentos, em especial os segmentos de negócios e eventos;

- melhoria nos aeroportos de menor porte, facilitando os vôos regionais;

- normatização da atividade e capacitação profissional, aumentando a oferta de produtos de qualidade. 


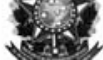

Ministério do Turismo

O fortalecimento do mercado interno vai impactar também positivamente os números do deslocamento rodoviário, que só não foram quantificados em metas, em função da confiabilidade dos registros existentes. 
5.5 - Ampliar a oferta turística brasileira, desenvolvendo no mínimo três produtos de qualidade em cada estado da Federação e Distrito Federal

A oferta turística do Brasil, tem se configurado pela promoção de poucos destinos em áreas pontuais, gerando produtos de apelo repetitivo.

Os produtos atualmente ofertados não contemplam a pluralidade cultural e a diversidade regional brasileira. Existe um potencial a ser revelado e trabalhado no interior do pais, e uma urgente necessidade de encontrar alternativas de desenvolvimento local e regional.

Desejamos desenvolver o turismo com base no principio da sustentabilidade, trabalhando de forma participativa, descentralizada e sistêmica, estimulando a integração e a consequente organização e ampliação da oferta.

O efetivo envolvimento dos governos estaduais, dos parceiros estratégicos, do setor privado, dos municípios e da comunidade é fundamental neste processo. Dessa forma cria-se o ambiente para alcançar a qualidade, a diversidade e competitividade do produto turistico brasileiro.

Com a meta estipulada teremos no minimo 81 produtos ofertados proporcionando condições para o aumento do fluxo doméstico e internacional de turistas e melhorando as condições socio-econômicas dos municipios e regiöes. 


\section{MACRO PROGRAMAS}

Os Macro Programas são desdobramentos temáticos que foram escolhidos pelo seu potencial de contribuição para atingir os compromissos estabelecidos nos OBJETIVOS e METAS para o turismo no período 2003 - 2007, bem como, resultado das contribuiçőes de todas as entidades do setor ouvidas e manifestas.

Os Macro Programas são construídos por um conjunto de programas que visam por seu intermédio, resdver os problemas e obstáculos que impedem 0 crescimento do Turismo no Brasil, identificados por um processo de consulta ao setor.

Esses Programas serāo detalhados em conjunto com as Câmaras Temáticas cujos Projetos e Ações seräo posteriormente executados, utilizando-se de um planejamento, da definição de prioridades, do orçamento e da avaliação de resultados 
$6.1-$ MACRO PROGRAMA 1 : GESTÃO E RELAÇÕES INSTITUCIONAIS

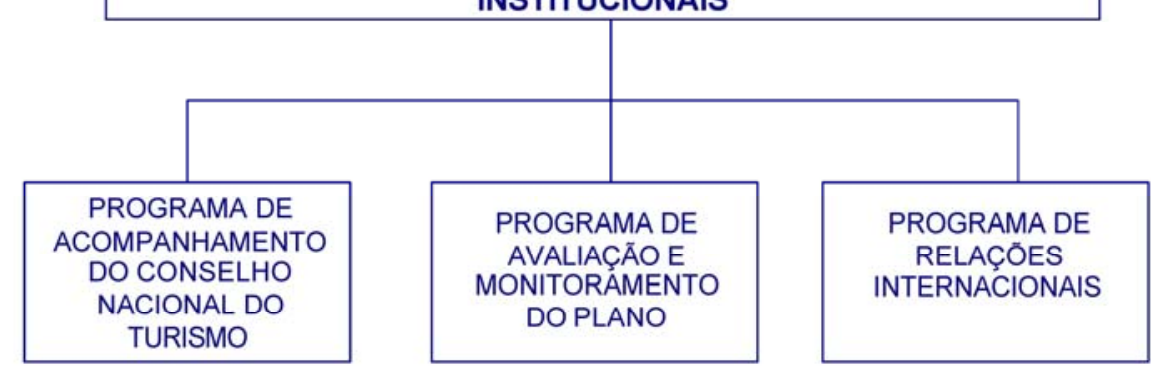

\section{a) Descrição}

As várias interfaces para o desenvolvimento do turismo necessitam de uma permanente articulação entre os diversos setores públicos e privados, no sentido de agilizar soluções, eliminar entraves burocráticos, compartilhar decisões e facilitar a participação de todos os envolvidos no processo de crescimento do setor.

Cabe ao Ministério do Turismo estabelecer as diversas interfaces com os distintos Ministérios e órgãos governamentais dos quais o turismo depende, direta e indiretamente.

Por outro lado é necessário fortalecer os canais representativos da iniciativa privada para solidificar a interlocução com o poder público.

A necessidade de existência de instrumentos de Gestão e Articulação com base nas relações de interesses institucionais levou-nos a criação do Conselho Nacional 
do Turismo cuja finalidade é auxiliar a elaboração e implantar o Plano Nacional do Turismo.

Serăo criados também os Fóruns Estaduais, com o objetivo de aglutinar os interesses, apresentar diagnósticos e propor soluçōes para as questōes que afetam o desenvolvimento do turismo.

Além das questões de natureza de articulação interna entre os setores públicos e privado é fundamental e necessário a participação efetiva do Brasil junto aos organismos internacionais do turismo.

Por meio desta ação devemos ampliar a cooperação técnica internacional e a implementação de acordos e tratados bilaterais e multilaterais que permitem a adequação das legislações e normas que afetam o incremento do turismo e visam um melhor aproveitamento da capacidade negociadora entre países e blocos econômicos.

No âmbito deste Macro Programa será estruturado um processo de avaliação e monitoramento de resultados dos projetos e açōes a serem implementadas pelo Plano Nacional de Turismo.

\section{b) Objetivos}

- Integrar os governos federal, estadual e municipal, descentralizando o processo de decisão no Turismo Brasileiro;

- integrar os setores público e privado e demais instituições otimizando recursos e dando eficiência às ações;

- monitorar e avaliar o resultados do plano nacional do turismo;

- participar dos fóruns internacionais de interesse do turismo. 
6.2

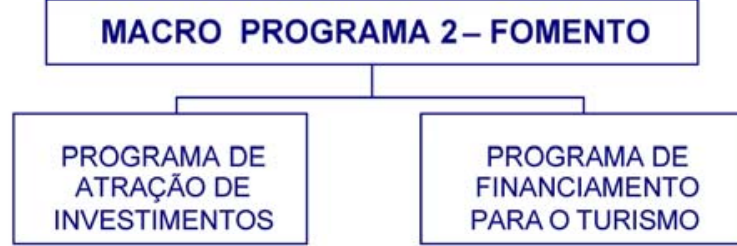

\section{a) Descrição}

A atividade turística é executada fundamentalmente pela iniciativa privada e envolve um amplo leque de oportunidades para a realização de empreendimentos e oferta de serviços. Para o crescimento do setor é necessário rever a ampliar a disponibilidade de linhas de crédito e financiamentos adequados à realidade de cada segmento, atendendo principalmente a pequena e média empresa que não tem tido facilidade de acesso ao crédito.

O financiamento ao consumidor final será o outro instrumento utilizado para fortalecer o mercado interno, facilitando as viagens no território brasileiro. Outro necessidade é a ampliação da infra estrutura turística. $O$ incentivo para construção de equipamentos turísticos dar-se-á, não só por meio da oferta de novas linhas de crédito, mas também pela identificação e cadastramento de projetos atrativos nos roteiros e destinos turísticos, para divulgação a potenciais investidores no Brasil e no exterior.

\section{a) Objetivos}

- Ampliar e melhorar a infra-estrutura turística em todo país;

- $\quad$ aquecer o mercado interno através do financiamento ao consumidor final;

- gerar divisas promovendo captação de investidores para o Brasil;

- incentivar a pequena e média empresa facilitando o acesso ao crédito;

- captar investidores para projetos localizados em regiōes potenciais remotas, ainda não desenvolvidas;

- gerar novos postos de trabalho por meio do aquecimento da atividade e da construção de novos equipamentos turísticos. 
$6.3-$

MACRO PROGRAMA 3- INFRA - ESTRUTURA

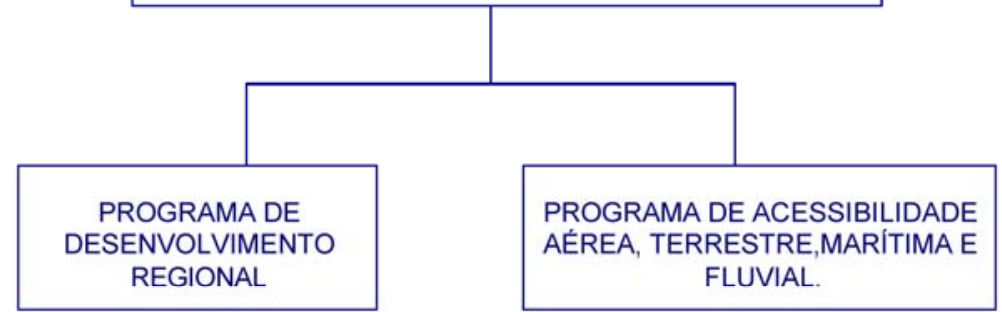

\section{a) Descrição}

A expansão do Parque Hoteleiro, dos equipamentos de lazer e entretenimento e a diversificação dos produtos turísticos, só podem ocorrer em um cenário onde a infra estrutura básica esteja disponível, garantindo não só a viabilidade dos investimentos, como a sua sustentabilidade ao longo do tempo.

As cidades, onde efetivamente o turismo acontece, necessitam de água, energia, transporte público, segurança, coleta e destino do lixo, tratamento de esgoto, comunicação, vias públicas e facilidade nos acessos.

Estas necessidades atingem os moradores e os turistas que visitam a localidade. A implementação do Prodetur Nordeste II , Sul, Centro, Proecotur Amazônia, Programa Pantanal; projetos financiados pelo Banco Interamericano de Desenvolvimento irão suprir em parte estas necessidades.

\section{b) Objetivos}

- melhorar a qualidade de vida nas cidades turísticas;

- criar condições para implantação de equipamentos turísticos;

- facilitar o acesso do fluxo de turistas;

- $\quad$ equilibrar o desenvolvimento das regiões brasileiras. 


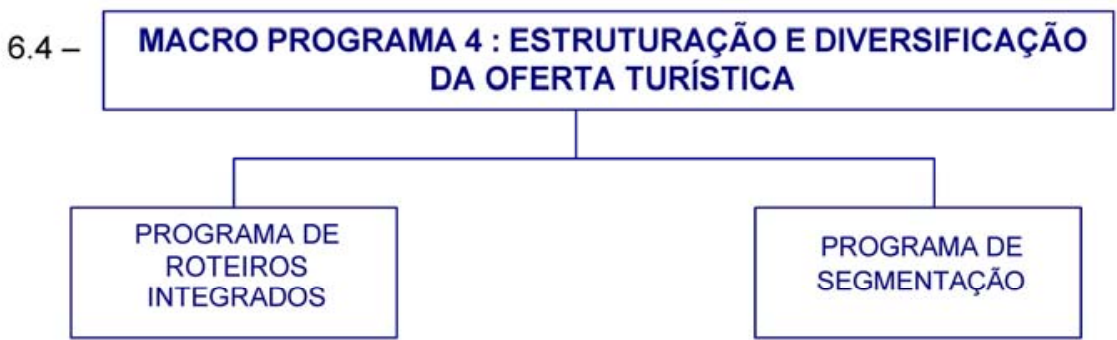

\section{a) Descrição}

A oferta do produto turístico Brasileiro tem se caracterizado pela pouca diversidade. Muito do que se tem hoje, colocado para comercialização é dentro de um número restrito de segmentos e em algumas regiões brasileiras

Estruturar e aumentar esta oferta, colocando no mercado, novos produtos de qualidade, compativeis com diversidade cultural e contemplando as diferentes regiöes brasileiras se constituem um grande desafio.

Tendo como fundamental a participação dos governos estaduais e de parceiros estratégicos do setor privado, realizaremos um consistente planejamento e executaremos as ações necessárias para estruturar e qualificar os roteiros Turísticos Integrados que serão constituídos pelos municípios organizados em consórcios.

O fortalecimento dos segmentos turísticos dar-se-á à partir da normatização e ordenamento destas práticas, objetivando torná-las competitivas no mercado internacional, principalmente no que tange aos aspectos de qualidade e segurança. 
Ministério do Turismo

A organização destes segmentos vêm no sentido de atender as demandas especificas de mercado, maximizando o aproveitamento das potencialidades e as diferenças de cada região brasileira.

\section{b) Objetivos}

- Aumentar o número de produtos turísticos de qualidade colocados para comercialização;

- diversificar os produtos turísticos contemplando nossa pluralidade cultural e diferença regional;

- diminuir as desigualdade regionais, estruturando produtos em todos os estados brasileiros e Distrito Federal;

- aumentar o fluxo de turistas nacional e internacional;

- aumentar o tempo de permanência do turista internacional com um leque maior de serviços ofertados. 


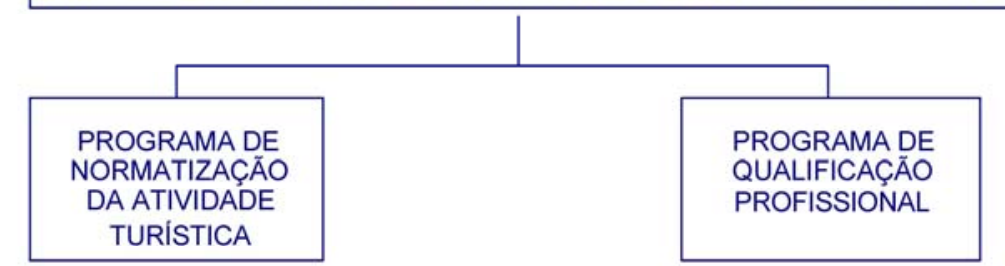

\section{a) Descrição}

A qualidade do produto turístico, mais do que uma vantagem competitiva é pressuposto fundamental para o sucesso dos destinos.

Num mundo onde centenas de destinos turísticos competem pela preferência dos turistas, se tornam fundamental a proposição de ações que levem à qualidade.

O estado tem papel importante a cumprir na regulamentação do setor, normatizando e fiscalizando segmentos e a atividade turística e orientando a formação profissional. É necessário aperfeiçoar os mecanismos para o aprimoramento dos serviços como também aplicar métodos para qualificar e difundir os níveis atingidos por meios de processos de certificação.

O grande número de empregos que gera o turismo e a alta rotatividade nos postos de trabalho, requerem um enorme esforço para a qualificação dos recursos humanos.

Da mesma forma, a incorporaçăo de novas tecnologias em cada uma das áreas de negócios turísticos exigem atualizações e adaptações às novas condições.

$\mathrm{Na}$ formação dos recurso humanos há de se considerar também uma dinâmica social e cultural do destino turístico bem como suas diferenciações regionais. 
O setor turístico se beneficiará ao contar com quadros melhores preparados, no que redunda um melhor serviço para o turista.

Atenção particular merecem as instituiçōes educativos, porque sobre elas recai o enorme compromisso de formar profissionais em todos os niveis para o setor.

Para garantir a confiabilidade nas relaçōes entre os prestadores de serviços turísticos e os consumidores faz-se necessários o estabelecimento de normas e padrões que sirvam de parâmetros para harmonizar as práticas relativas à comercialização dos produtos.

É necessário fornecer ao consumidor nacional e estrangeiros um referencial de qualidade, de modo a garantir os seus direitos quando da aquisição de um produto ou serviço turístico.

Neste sentido, este macro- programa busca desempenhar um papel de indutor da qualificação dos serviços prestados e a estimular os mecanismos de Fiscalização para evitar a prática de abusos, tanto nas ralaçōes internas do setor quanto na venda ao consumidor.

\section{b) Objetivos}

- $\quad$ Promover a qualidade dos produtos turísticos no Brasil;

- $\quad$ apoiar programação de certificação da qualidade para as empresas setor;

- estabelecer em cooperação com as entidades representativas dos segmentos turísticos, normas padrōes e regulamentos relativos aos serviços prestados para referenciar os programas de qualificação profissional e orientar a melhoria da qualidade e segurança dos serviços prestados ao turista;

- descentralizar e fortalecer o sistema de fiscalização delegada dos serviços turísticos; 
Ministério do Turismo

- intensificar esforços voltados para o cumprimento das normas e regulamentos para os serviços facilitando a garantia da defesa do consumidor turista;

- promover a capacitação, qualificação e a re-qualificação dos agentes atuantes em toda cadeia produtiva do turismo, nos diversos níveis hierárquicos, tanto do setor público quanto do setor privado visando ocupar os novos postos de trabalho gerados. 


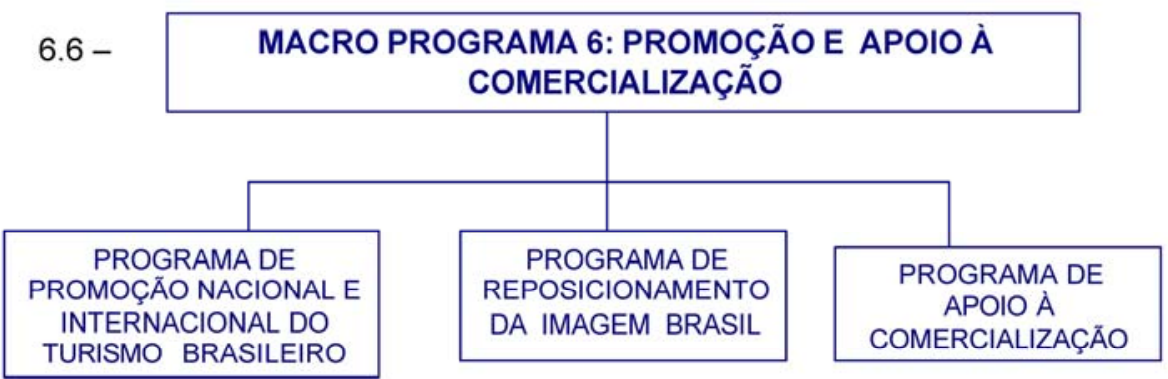

\section{a) Descrição}

A promoção do turismo brasileiro no mercado internacional terá como conceito estratégico a diversificação de imagem do país. As ações de promoção e marketing irão orientar a construção do Brasil como destino turístico de um país moderno, com credibilidade, alegre, jovem, hospitaleiro, capaz de proporcionar lazer de qualidade, novas experiências aos visitantes, realizar negócios, eventos e incentivos e ser competitivo internacionalmente. Os programas de promoção e marketing terão como essência a qualidade e a diversidade da produção cultural brasileira, além de nossa diversidade étnica, social e natural.

No mercado interno, o turismo deverá possibilitar o aumento das viagens por diversas motivações, preços e produtos acessíveis, de qualidade e que proporcionem experiências positivas de conhecimento, integração e valorização das riquezas culturais do país. Da mesma forma, o acesso ao turismo deverá ser democratizado, possibilitando que novas camadas sociais se integrem à realização de viagens.

Com profissionalismo, as ações terăo planejamento, continuidade e, sobretudo, se traduzirão em formas criativas e inovadoras de comunicação e distribuição nos principais paises emissores do mercado internacional e doméstico. Os mecanismos de apoio à comercialização dos produtos turísticos irão fortalecer os mercados já existentes 
Ministério do Turismo

e, a médio e longo prazos, incorporar novos mercados. Internamente, o turismo deverá possibilitar as viagens às diversas camadas sócio-econômicos, informando e incentivando o conhecimento da diversidade dos produtos nacionais.

\section{b) Objetivos}

- Aumentar o fluxo de turistas estrangeiros no Brasil realizando intensa promoção nos grandes mercados emissores internacionais e no mercado sul-americano;

- aquecer o mercado interno, promovendo um número maior de produtos de qualidade;

- $\quad$ promover a diversidade cultural e regional brasileira;

- promover as diferentes regiōes brasileiras diminuindo as suas desigualdades;

- fortalecer o segmento de negócios, captando uma quantidade maior de eventos para o Brasil. 


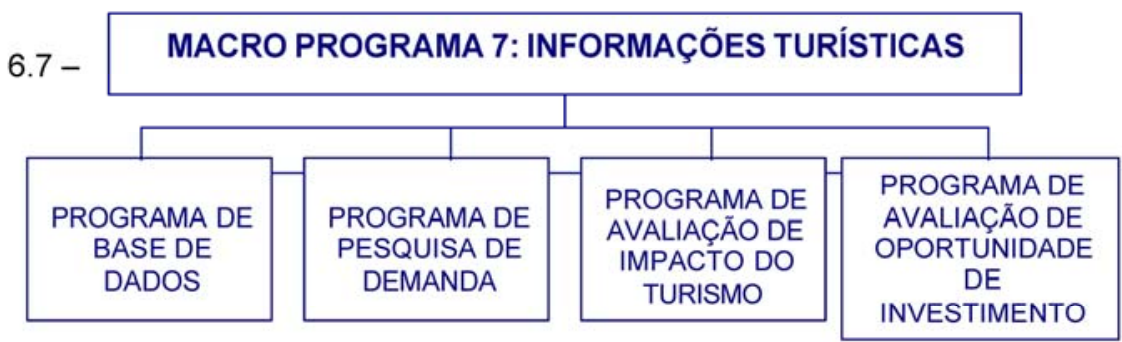

a) Descrição

A atividade turística depende intensamente de informações que facilitem o seu desenvolvimento.

É necessário um programa contínuo, que não só pesquise a oferta, mas também a demanda. Um sistema que avalie o impacto da atividade na economia, criando condiçőes para o fortalecimento do setor junto à sociedade.

Os dirigentes públicos e privados necessitam de informações essenciais para a tomada de decisão gerencial e para a captação e implementação de novos empreendimentos turísticos.

A produção e disseminação das informaçōes văo proporcionar o aparecimento de uma nova cultura, referencial no setor, baseado em números e pesquisas contínuos e confiáveis, facilitando a profissionalização e otimizando a aplicação dos recursos públicos e privados.

\section{b) Objetivos}

- Conhecer a oferta turística do mercado nacional;

- $\quad$ avaliar o impacto da atividade turística na economia;

- dar suporte as ações de promoção, marketing e apoio à comercialização do produto Brasil; 


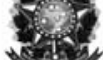

Ministério do Turismo

- dar suporte à tomada de decisão de dirigentes públicos e privados do turismo;

- conhecer a demanda do mercado internacional;

- dar suporte a decisão de potenciais investidores no setor de turismo. 


\section{ENTIDADES QUE CONTRIBUIRAM COM PROPOSTAS PARA} ELABORAÇÃO DO PLANO NACIONAL DO TURISMO

ABAV - Associação Brasileira de .Agências de Viagem.

ABBTUR - Associação Brasileira dos Bacharéis em Turismo.

ABCMI - Associação Brasileira dos Clubes da Melhor Idade.

ABEOC - Associação Brasileira de Empresas de Eventos.

$A B I H$ - Associação Brasileira da Indústria Hoteleira.

ABLA - Associação Brasileira de Locadoras de Automóveis

ABRACCEF - Associação Brasileira dos Centros de Convenções e Feiras.

ABRASEL - Associação Brasileira de Restaurantes e Empresas de Entretenimento.

ABRATURR - Associação Brasileira de Turismo Rural.

ABRESI - Associação Brasileira das Entidades de Hospedagem, Alimentação e Turismo.

ADIBRA - Associação das Empresas de Diversão do Brasil.

AMPRO - Associação de Marketing Promocional.

ANTTUR - Associação Nacional de Transportadores de Turismo.

Banco do Brasil

BITO - Brazilian Incoming Tour Operator.

BRAZTOA - Associação Brasileira das Operadoras de Turismo.

Caixa Econômica Federal

CBTS - Conselho Brasileiro de Turismo Sustentável.

CNC-Confederação Nacional do Comércio.

CONTRATUH - Confederação Nacional dos Trabalhadores em Turismo e Hotelaria.

Dunnas Off-Road Expedições.

FBAJ - Federação Brasileira dos Albergues da Juventude.

FBC \& VB - Federação Brasileira de Convention \& Visitors Bureaux.

FENACTUR - Federação Nacional do Turismo.

FENAGTUR - Federação Nacional dos Guias de Turismo. 
Ministério do Turismo

FHBRS - Federação Nacional de Hotéis, Restaurantes, Bares e Similares.

FORNATUR - Fórum Nacional de Secretários e Dirigentes Estaduais de Turismo.

IH - Instituto de Hospitalidade

Ministério da Integração Nacional.

Ministério do Trabalho e Emprego.

PARLATUR - Frente Parlamentar do Turismo.

São Paulo Convention \& Visitors Bureaux.

SEBRAE - Serviço Brasileiro de Pequenas e Médias Empresas

SECOM - Secretaria de Comunicaçăo da Presidência da República Federal.

SENAC - Serviço Nacional de Aprendizagem Comercial.

SENAI - Serviço Nacional de Aprendizagem Industrial.

SENAR - Serviço Nacional de Aprendizagem Rural.

SESC - Serviço Social do Comércio.

SNEA - Sindicato Nacional das Empresas Aeroviárias.

Sub-Comissão de Turismo da Câmara dos Deputados.

UBRAFE - União Brasileira de Promotores de Feiras.

Urlaub Viagens e Turismo Ltda. 
Ministério do Turismo

\section{DOCUMENTOS CONSULTADOS}

- Evolução do Turismo no Brasil - 1992/2001 - EMBRATUR.

- Subsídios a Formulação da Política Nacional de Turismo ( Carta de Turismo ANHEMBI - MORUMBI ).

- $\quad$ Carta de Goiás - Agenda Única do Turismo Nacional - Ano 2000 - Frente Parlamentar de Turismo.

- $\quad$ EMBRATUR - Plano de Trabalho - 2003 - 2007.

- $\quad$ Programa Brasileiro da Atividade Turística - 2002

- CNC - Sub-Comissão Permanente de Turismo da Câmara dos Deputados.

- Programa Nacional de Turismo - 2001-2006 - México.

- Política Nacional de Turismo - 2002 - França. 
Anexo C

Composição do Conselho Nacional de Turismo - CNT, cedido pela

Coordenação do CNT 


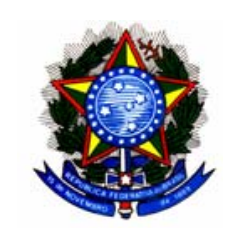

MINISTÉRIO DO TURISMO

Conselho Nacional de Turismo

RELAÇÃo de ConselHeiros Titulares E SUPLENTES

Atualizada 27/06/05

\begin{tabular}{|c|c|c|}
\hline ENTIDADE & CONSELHEIRO TITULAR & CONSELHEIRO SUPLENTE \\
\hline $\begin{array}{c}\text { ABAV } \\
\text { Associação Brasileira de } \\
\text { Agências de Viagens }\end{array}$ & JOÃO PEREIRA MARTINS NETO & EUGÊNIO ANTINORO \\
\hline $\begin{array}{c}\text { ABBTUR } \\
\text { Associação Brasileira dos } \\
\text { Bacharéis em Turismo }\end{array}$ & NOSLIN DE PAULA ALMEIDA & SÉRGIO FERNANDES MARTINS \\
\hline $\begin{array}{c}\text { ABCMI NACIONAL } \\
\text { Associação Brasileira dos } \\
\text { Clubes da Melhor Idade } \\
\end{array}$ & GENILDA CORDEIRO BARONE & $\begin{array}{l}\text { DECY BRUM VIGIOLE DE } \\
\text { CACICOLI. }\end{array}$ \\
\hline $\begin{array}{c}\text { ABEOC } \\
\text { Associação Brasileira de } \\
\text { Empresas de Eventos }\end{array}$ & $\begin{array}{l}\text { JUAREZ AUGUSTO DE } \\
\text { CARVALHO FILHO }\end{array}$ & SIMONE SACCOMAN MARQUES \\
\hline $\begin{array}{c}\text { ABETA } \\
\text { Associação Brasileira das } \\
\text { Empresas de Turismo de } \\
\text { Aventura } \\
\end{array}$ & $\begin{array}{l}\text { FELIPE AUGUSTO ARAGÃO } \\
\text { EVANGELISTA JÚNIOR }\end{array}$ & GUSTAVO FRAGA TIMO \\
\hline $\begin{array}{c}\text { ABETAR } \\
\text { Associação Brasileira das } \\
\text { Empresas Aéreo Regional }\end{array}$ & ÁTILA YURTSEVER & $\begin{array}{l}\text { APÓSTOLE LAZARO } \\
\text { CHRYSSAFIDIS }\end{array}$ \\
\hline $\begin{array}{c}\text { ABIH } \\
\begin{array}{l}\text { Associação Brasileira da } \\
\text { Indústria Hoteleira }\end{array}\end{array}$ & ERALDO ALVES DA CRUZ & $\begin{array}{c}\text { ALEXANDRE SAMPAIO DE } \\
\text { ABREU }\end{array}$ \\
\hline $\begin{array}{c}\text { ABLA } \\
\text { Associação Brasileira das } \\
\text { Locadoras de Automóveis }\end{array}$ & $\begin{array}{c}\text { ALBERTO DE CAMARGO } \\
\text { VIDIGAL }\end{array}$ & $\begin{array}{l}\text { CARLOS ROBERTO PINTO } \\
\text { FAUSTINO }\end{array}$ \\
\hline $\begin{array}{c}\text { ABR } \\
\text { Associação Brasileira de } \\
\text { Resorts }\end{array}$ & $\begin{array}{l}\text { ALEXANDRE ADILSON } \\
\text { ZUBARAN DE OLIVEIRA }\end{array}$ & RUBENS AUGUSTO REGIS \\
\hline $\begin{array}{c}\text { ABRACAMPING } \\
\text { Associação Brasileira de } \\
\text { Campismo }\end{array}$ & LUIZ EDGAR PEREIRA TOSTES & $\begin{array}{l}\text { LUIZ ANTONIO PINTO } \\
\text { MATHEUS }\end{array}$ \\
\hline $\begin{array}{l}\text { ABRACCEF Associação } \\
\text { Brasileira de Centros de } \\
\text { Convenções e Feiras }\end{array}$ & $\begin{array}{l}\text { MARGARETH SOBRINHO } \\
\text { PIZZATO }\end{array}$ & MÁRIO LIBERALLI DE GÓES \\
\hline $\begin{array}{c}\text { ABRAJET Associação } \\
\text { Brasileira de Jornalistas de } \\
\text { Turismo } \\
\end{array}$ & CLÁUDIO MAGNAVITA CASTRO & RICARDO GUERRA \\
\hline $\begin{array}{l}\text { ABRASEL Associação } \\
\text { Brasileira de Restaurantes e } \\
\text { Empresas de Entretenimento }\end{array}$ & PAULO SOLMUCCI JÚNIOR & MARIA DE FÁTIMA HAMBÚ \\
\hline $\begin{array}{c}\text { ABRASTUR } \\
\text { Associação Brasileira de } \\
\text { Cooperativas e Clubes de } \\
\text { Turismo Social } \\
\end{array}$ & PAULO DE BRITO FREITAS & $\begin{array}{c}\text { EDUARDO JOSÉ FERREIRA } \\
\text { BARNES }\end{array}$ \\
\hline $\begin{array}{c}\text { ABRATURR Associação } \\
\text { Brasileira de Turismo Rural }\end{array}$ & CARLOS ROBERTO SOLERA & $\begin{array}{c}\text { PAULO EDUARDO JUNQUEIRA } \\
\text { DE ARANTES }\end{array}$ \\
\hline $\begin{array}{c}\text { ABRESI } \\
\text { Associação Brasileira das } \\
\text { Entidades de Gastronomia, } \\
\text { Hospitalidade e Turismo }\end{array}$ & NELSON DE ABREU PINTO & RONALD STARLING SOARES \\
\hline $\begin{array}{c}\text { ADIBRA } \\
\text { Associação das Empresas de } \\
\text { Parques de Diversões do } \\
\text { Brasil }\end{array}$ & ALAIN JEAN PIERRE BALDACCI & ARMANDO PEREIRA FILHO \\
\hline
\end{tabular}




\begin{tabular}{|c|c|c|}
\hline $\begin{array}{c}\text { ANTTUR } \\
\text { Associação Nacional dos } \\
\text { Transportadores de Turismo }\end{array}$ & $\begin{array}{c}\text { MARTINHO FERREIRA DE } \\
\text { MOURA }\end{array}$ & SHIGUEO MATSUNAGA \\
\hline $\begin{array}{c}\text { BASA } \\
\text { Banco da Amazônia S.A. }\end{array}$ & $\begin{array}{l}\text { JOÃO BATISTA DE MELO } \\
\text { BASTOS }\end{array}$ & $\begin{array}{l}\text { EVANDRO BESSA DE LIMA } \\
\text { FILHO }\end{array}$ \\
\hline $\begin{array}{c}\text { BB } \\
\text { Banco do Brasil } \\
\end{array}$ & $\begin{array}{l}\text { RICARDO ALVES DA } \\
\text { CONCEIÇÃO }\end{array}$ & JOÃO CARLOS DE MATTOS \\
\hline $\begin{array}{c}\text { BITO } \\
\text { Associação Brasileira de } \\
\text { turismo Receptivo }\end{array}$ & ROBERTO ALMEIDA DUTRA & $\begin{array}{l}\text { VERA MARIA MENDONÇA } \\
\text { POTTER }\end{array}$ \\
\hline $\begin{array}{c}\text { BNB } \\
\text { Banco do Nordeste do Brasil }\end{array}$ & ROBERTO SMITH & $\begin{array}{c}\text { PEDRO EUGÊNIO DE CASTRO } \\
\text { TOLEDO CABRAL }\end{array}$ \\
\hline $\begin{array}{c}\text { BNDES } \\
\text { Banco Nacional de } \\
\text { Desenvolvimento Econômico } \\
\text { e Social }\end{array}$ & $\begin{array}{l}\text { ALBERTO DE OLIVEIRA } \\
\text { CONSTANTINO }\end{array}$ & $\begin{array}{c}\text { CARLOS EDUARDO CASTELO } \\
\text { BRANCO }\end{array}$ \\
\hline $\begin{array}{c}\text { BRAZTOA Associação } \\
\text { Brasileira das Operadoras de } \\
\text { Turismo }\end{array}$ & JOSÉ ZUQUIM & $\begin{array}{l}\text { RODOLPHO CARLOS } \\
\text { GERSTNER }\end{array}$ \\
\hline $\begin{array}{c}\text { CAIXA } \\
\text { Caixa Econômica Federal }\end{array}$ & $\begin{array}{l}\text { JORGE EDUARDO LEVI } \\
\text { MATTOSO }\end{array}$ & FÁBIO LENZA \\
\hline $\begin{array}{l}\text { Casa Civil da Presidência da } \\
\text { República }\end{array}$ & SHEILA RIBEIRO FERREIRA & VINÍCIUS TEIXEIRA SUCENA \\
\hline $\begin{array}{c}\text { CNC } \\
\text { Confederação Nacional do } \\
\text { Comércio }\end{array}$ & ANTONIO OLIVEIRA SANTOS & NORTON LUIZ LENHART \\
\hline $\begin{array}{c}\text { CNM } \\
\begin{array}{c}\text { Confederação Nacional dos } \\
\text { Municípios }\end{array} \\
\end{array}$ & PAULO ROBERTO ZIULKOSKI & $\begin{array}{l}\text { ANNA MARIA MARCONDES } \\
\text { MACHADO }\end{array}$ \\
\hline $\begin{array}{c}\text { CONTRATUH Confederação } \\
\text { Nacional dos Trabalhadores } \\
\text { em Turismo e Hotelaria }\end{array}$ & $\begin{array}{c}\text { MOACYR ROBERTO TESCH } \\
\text { AUERSVALD }\end{array}$ & $\begin{array}{l}\text { ROGÉRIO JOSÉ GOMES } \\
\text { CARDOSO }\end{array}$ \\
\hline $\begin{array}{c}\text { EMBRATUR } \\
\text { Instituto Brasileiro de } \\
\text { Turismo }\end{array}$ & EDUARDO SANOVICZ & GERALDO LIMA BENTES \\
\hline $\begin{array}{c}\text { FBAJ } \\
\text { Federação Brasileira dos } \\
\text { Albergues da Juventude }\end{array}$ & $\begin{array}{l}\text { CARLOS AUGUSTO SILVEIRA } \\
\text { ALVES }\end{array}$ & MARIA JOSÉ GIARETTA \\
\hline $\begin{array}{c}\text { FBC\&VB } \\
\text { Federação Brasileira de } \\
\text { Convention \& Visitors Bureau }\end{array}$ & $\begin{array}{c}\text { JOÃO LUIZ DOS SANTOS } \\
\text { MOREIRA }\end{array}$ & $\begin{array}{l}\text { PAULO CÉSAR BOECHAT } \\
\text { LEMOS }\end{array}$ \\
\hline $\begin{array}{c}\text { FENACTUR Federação } \\
\text { Nacional de Turismo }\end{array}$ & MICHEL TUMA NESS & $\begin{array}{l}\text { MÁRIO EDMUNDO J. LOBO } \\
\text { FILHO }\end{array}$ \\
\hline $\begin{array}{c}\text { FENAGTUR Federação } \\
\text { Nacional de Guias de Turismo }\end{array}$ & CREUSA DE SOUSA SOARES & IACY DA MATA VASCONCELOS \\
\hline $\begin{array}{c}\text { FNHRBS } \\
\text { Federação Nacional de } \\
\text { Hotéis, Restaurantes, Bares e } \\
\text { Similares } \\
\end{array}$ & NORTON LUIZ LENHART & $\begin{array}{l}\text { ALEXANDRE SAMPAIO DE } \\
\text { ABREU }\end{array}$ \\
\hline $\begin{array}{c}\text { FOHB } \\
\text { Fórum de Operadores } \\
\text { Hoteleiros no Brasil. }\end{array}$ & ROLAND DE BONADONA & RAFAEL GASPARI \\
\hline $\begin{array}{c}\text { FORNATUR } \\
\text { Fórum Nacional de } \\
\text { Secretários e Dirigentes de } \\
\text { Turismo }\end{array}$ & $\begin{array}{l}\text { MARCELO DE OLIVEIRA } \\
\text { SAFADI }\end{array}$ & $\begin{array}{c}\text { SERGIO RICARDO MARTINS DE } \\
\text { ALMEIDA }\end{array}$ \\
\hline $\begin{array}{c}\text { Fórum Nacional dos Cursos } \\
\text { Superiores de Turismo e } \\
\text { Hotelaria }\end{array}$ & $\begin{array}{c}\text { JUREMA MARCIA DANTAS DA } \\
\text { SILVA }\end{array}$ & EDUARDO FLÁVIO ZARDO \\
\hline Indicação Presidente & GUILHERME PAULUS & $\begin{array}{l}\text { VIRGÍLIO NELSON DA SILVA } \\
\text { CARVALHO }\end{array}$ \\
\hline Indicação Presidente & MÁRIO CARLOS BENI & NORMA MARTINI MOESCH \\
\hline Indicação Presidente & SERGIO FOGUEL & $\begin{array}{l}\text { LUIZ FELIPE CARNEIRO DA } \\
\text { CRUZ }\end{array}$ \\
\hline
\end{tabular}




\begin{tabular}{|c|c|c|}
\hline $\begin{array}{c}\text { INFRAERO } \\
\text { Empresa Brasileira de Infra- } \\
\text { Estrutura Aeroportuária }\end{array}$ & $\begin{array}{l}\text { FERNANDO BRENDAGLIA DE } \\
\text { ALMEIDA MACHADO }\end{array}$ & $\begin{array}{l}\text { LEUR ANTÔNIO DE BRITTO } \\
\text { LOMANTO }\end{array}$ \\
\hline $\begin{array}{c}\text { MD } \\
\text { Ministério da Defesa } \\
\end{array}$ & $\begin{array}{l}\text { ANTÔNIO CARLOS AYROSA } \\
\text { ROSIERE }\end{array}$ & RIGOBERT LUCHT \\
\hline $\begin{array}{c}\text { MDA } \\
\text { Ministério do } \\
\text { Desenvolvimento Agrário } \\
\end{array}$ & HUR BEN CORREIA DA SILVA & KLEBER BATISTA PETTAN \\
\hline $\begin{array}{c}\text { MDIC } \\
\text { Ministério do } \\
\text { Desenvolvimento, Indústria e } \\
\text { Comércio Exterior }\end{array}$ & LUIZ FERNANDO FURLAN & $\begin{array}{l}\text { MARCOS OTÁVIO BEZERRA } \\
\text { PRATES }\end{array}$ \\
\hline $\begin{array}{c}\text { MF } \\
\text { Ministério da Fazenda }\end{array}$ & $\begin{array}{c}\text { ANA PAULA VITALI JANES } \\
\text { VESCOVI }\end{array}$ & LEANDRO FONSECA DA SILVA \\
\hline $\begin{array}{c}\text { MIN } \\
\begin{array}{c}\text { Ministério da Integração } \\
\text { Nacional }\end{array}\end{array}$ & $\begin{array}{c}\text { CARLOS AUGUSTO GRABOIS } \\
\text { GADELHA }\end{array}$ & $\begin{array}{l}\text { ROGÉRIO OLIVEIRA DE } \\
\text { CASTRO VIEIRA }\end{array}$ \\
\hline $\begin{array}{c}\text { MINC } \\
\text { Ministério da Cultura }\end{array}$ & $\begin{array}{c}\text { PAULO CÉSAR MIGUEZ DE } \\
\text { OLIVEIRA }\end{array}$ & $\begin{array}{l}\text { MÁRCIA GENESIA DE } \\
\text { SANT'ANNA }\end{array}$ \\
\hline $\begin{array}{c}\text { MJ } \\
\text { Ministério da Justiça }\end{array}$ & $\begin{array}{l}\text { MYRIAM BRÉA HONORATO DE } \\
\text { SOUZA }\end{array}$ & $\begin{array}{l}\text { JOSÉ MARCELO SALLOVITZ } \\
\text { ZACCHI }\end{array}$ \\
\hline $\begin{array}{c}\text { MMA } \\
\text { Ministério do Meio Ambiente }\end{array}$ & GILNEY AMORIM VIANA & NAZARÉ LIMA SOARES \\
\hline $\begin{array}{c}\text { MPO } \\
\text { Ministério do Planejamento, } \\
\text { Orçamento e Gestão. }\end{array}$ & $\begin{array}{l}\text { MARCOS REGINALDO } \\
\text { PANARIELLO }\end{array}$ & $\begin{array}{l}\text { LILIAN GIL BARBOSA DE } \\
\text { ARAGÃO }\end{array}$ \\
\hline $\begin{array}{c}\text { MRE } \\
\text { Ministério das Relações } \\
\text { Exteriores. }\end{array}$ & EMBAIXADOR MÁRIO VILALVA & SERGIO LUIZ CANAES \\
\hline $\begin{array}{c}\text { MT } \\
\text { Ministério do Transporte }\end{array}$ & $\begin{array}{l}\text { SÉRGIO HERMES MARTELLO } \\
\text { BACCI }\end{array}$ & FÁBIO JOSÉ MACIOTTI COSTA \\
\hline $\begin{array}{c}\text { MTE } \\
\text { Ministério do Trabalho e do } \\
\text { Emprego }\end{array}$ & FRANCO DE MATOS & ALMERICO BIONDI LIMA \\
\hline $\begin{array}{c}\text { MTUR } \\
\text { Ministério do Turismo }\end{array}$ & WALFRIDO DOS MARES GUIA & $\begin{array}{l}\text { MÁRCIO FAVILLA LUCCA DE } \\
\text { PAULA }\end{array}$ \\
\hline $\begin{array}{c}\text { SEBRAE } \\
\text { Serviço Brasileiro de Apoio } \\
\text { às Micro e Pequenas } \\
\text { Empresas. }\end{array}$ & LUIZ CARLOS BARBOSA & VINICIUS NOBRE LAGES \\
\hline $\begin{array}{c}\text { SENAC } \\
\text { Serviço Nacional do } \\
\text { Comércio. }\end{array}$ & SIDNEY DA SILVA CUNHA & $\begin{array}{c}\text { ANTÔNIO HENRIQUE BORGES } \\
\text { PAULA }\end{array}$ \\
\hline $\begin{array}{c}\text { SNEA } \\
\begin{array}{c}\text { Sindicato Nacional dos Empr. } \\
\text { Aeroviários. }\end{array} \\
\end{array}$ & GEORGE ERMAKOFF & ADELITA GUASCO \\
\hline $\begin{array}{l}\text { SUFRAMA Superitendência } \\
\text { da Zona Franca de Manaus }\end{array}$ & $\begin{array}{l}\text { JOSÉ ALBERTO DA COSTA } \\
\text { MACHADO }\end{array}$ & $\begin{array}{l}\text { ELIANY MARIA DE SOUZA } \\
\text { GOMES }\end{array}$ \\
\hline $\begin{array}{c}\text { UBRAFE } \\
\text { União Brasileira dos } \\
\text { Promotores de Feira. }\end{array}$ & DÁRCIO BERTOCCO & $\begin{array}{l}\text { ARMANDO ARRUDA PEREIRA } \\
\text { CAMPOS MELLO }\end{array}$ \\
\hline
\end{tabular}


Anexo D

Programa Nacional do Patrimônio Imaterial - IPHAN, Ministério da Cultura, 2000. Disponível na internet: www.iphan.gov.br. 


\section{O PROGRAMA NACIONAL DO PATRIMÔNIO IMATERIAL}

O Programa Nacional do Patrimônio Imaterial/PNPI, instituído pelo Decreto $\mathrm{n}^{\circ}$ 3.551, de 4 de agosto de 2000, viabiliza projetos de identificação, reconhecimento, salvaguarda e promoção da dimensão imaterial do patrimônio cultural. É um programa de fomento que busca estabelecer parcerias com instituições dos governos federal, estadual e municipal, universidades, organizações não-governamentais, agências de desenvolvimento e organizações privadas ligadas à cultura, à pesquisa e ao financiamento.

\section{Objetivos:}

- Implementar política de inventário, registro e salvaguarda de bens culturais de natureza imaterial.

- Contribuir para a preservação da diversidade étnica e cultural do país e para a disseminação de informações sobre o patrimônio cultural brasileiro a todos os segmentos da sociedade.

- Captar recursos e promover a constituição de uma rede de parceiros com vistas à preservação, valorização e ampliação dos bens que compõem o patrimônio cultural brasileiro.

- Incentivar e apoiar iniciativas e práticas de preservação desenvolvidas pela sociedade.

\section{Diretrizes da política de fomento do PNPI}

- Promover a inclusão social e a melhoria das condições de vida de produtores e detentores do patrimônio cultural imaterial. 
- Ampliar a participação dos grupos que produzem, transmitem e atualizam manifestações culturais de natureza imaterial nos projetos de preservação e valorização desse patrimônio.

- Promover a salvaguarda de bens culturais imateriais por meio do apoio às condições materiais que propiciam sua existência, bem como pela ampliação do acesso aos benefícios gerados por essa preservação.

- Implementar mecanismos para a efetiva proteção de bens culturais imateriais em situação de risco.

- Respeitar e proteger direitos difusos ou coletivos relativos à preservação e ao uso do patrimônio cultural imaterial.

\section{Linhas de Ação}

O PNPI financia, apóia e estimula, prioritariamente, projetos inseridos nas seguintes linhas de ação:

- Pesquisa, documentação e informação

- Sustentabilidade

- Promoção

- Capacitação

\section{Exemplos de projetos financiados pelo PNPI}

- Inventário Celebrações e Saberes da Cultura Popular - desenvolvido pelo Centro Nacional de Folclore e Cultura Popular, estrutura-se segundo quatro grandes linhas de abordagem de nossa diversidade cultural: os usos culinários do feijão e da mandioca, as celebrações que têm o boi como tema, o barro e a 
cerâmica tradicional e as formas de expressão proporcionadas pelas violas e instrumentos de percussão.

- Planos de salvaguarda dos bens culturais registrados - o Ofício das Paneleiras de Goiabeiras, no Espírito Santo, e a Arte Gráfica Kusiwa dos índios Wajãpi, do Amapá.

- Projeto Multiculturalismo em situação urbana - inventário de referências culturais na região do bairro do Bom Retiro, desenvolvido pelo Iphan em parceria com o Departamento de Patrimônio Histórico do Município de São Paulo.

- Referências Culturais dos Povos Indígenas do Alto Rio Negro/AM - inventário junto a populações indígenas da região, desenvolvido pelo Iphan em parceria com a Federação das Organizações Indígenas do Rio Negro e com o Instituto Socioambiental.

- Rotas da Alforria - trajetórias da população afro-descendente na região de Cachoeira/BA - projeto de desenvolvimento integrado desenvolvido pelo Iphan em parceria com várias instituições locais.

- Referências culturais das populações da região do Parque Nacional Grande Sertão Veredas/MG - inventário programado pelo Iphan em parceira com a Funatura, organização não-governamental responsável pela gestão do parque.

- Projetos de Inventários de Referências Culturais em 15 estados brasileiros, sob a responsabilidade de Superintendências Regionais do Iphan.

$\underline{\text { Outros instrumentos da política de preservação do patrimônio cultural imaterial }}$ $\underline{\text { brasileiro }}$

- Registro de bens culturais de natureza imaterial 
- Inventário Nacional de Referências Culturais - INRC

O INRC tem como objetivo produzir conhecimento sobre os domínios da vida social aos quais são atribuídos sentidos e valores e que, portanto, constituem marcos e referências de identidade para determinado grupo social. Contempla, além das categorias estabelecidas no Registro, edificações associadas a certos usos, a significações históricas e a imagens urbanas, independentemente de sua qualidade arquitetônica ou artística.

A delimitação da área do inventário ocorre em função das referências culturais presentes num determinado território. Essas áreas podem ser reconhecidas em diferentes escalas, ou seja, podem corresponder a uma vila, a um bairro, a uma zona ou mancha urbana, a uma região geográfica culturalmente diferenciada ou mesmo a um conjunto de segmentos territoriais.

\section{Planos de Salvaguarda}

Salvaguardar um bem cultural de natureza imaterial é apoiar sua continuidade de modo sustentável. É atuar no sentido da melhoria das condições sociais e materiais de transmissão e reprodução que possibilitam sua existência.

O conhecimento gerado durante os processos de inventário e Registro é o que permite identificar de modo bastante preciso as formas mais adequadas de salvaguarda. Essas formas podem ir desde a ajuda financeira a detentores de saberes específicos com vistas à sua transmissão, até, por exemplo, a organização comunitária ou a facilitação de acesso a matérias primas.

\section{Bens culturais de natureza imaterial}

- Bens registrados 6 
- Processos de registro em andamento 9

- Inventários realizados 4

- Inventários em andamento 25

- Obra-prima do Patrimônio Oral e Imaterial da Humanidade 1

\section{Registro de Bens Culturais de Natureza Imaterial}

Instituído pelo Decreto $\mathrm{n}^{\circ} 3.551$, de 4 de agosto de 2000, o Registro é o instrumento legal para reconhecimento e valorização do patrimônio cultural imaterial brasileiro. Os bens registrados são inscritos nos Livros de Registro dos Saberes, das Celebrações, das Formas de Expressão e dos Lugares.

- Os saberes ou modos de fazer são atividades desenvolvidas por atores sociais conhecedores de técnicas e de matérias-primas que identificam um grupo social ou uma localidade.

- As celebrações são ritos e festividades associados à religiosidade, à civilidade e aos ciclos do calendário, que participam fortemente da produção de sentidos específicos de lugar e de território.

- As formas de expressão são formas não-lingüísticas de comunicação associadas a determinado grupo social ou região, traduzidas em manifestações musicais, cênicas, plásticas, lúdicas ou literárias.

- Lugares são espaços onde ocorrem práticas e atividades de naturezas variadas, tanto cotidianas quanto excepcionais, que constituem referência para a população.

$\underline{\text { Tramitação dos processos de Registro de Bens Culturais de Natureza Imaterial }}$ 
A instauração do processo de Registro tem início com a abertura de um

Dossiê de Estudos. Após a conclusão da instrução técnica, o Dossiê é encaminhado ao Conselho Consultivo do Patrimônio Cultural e só então recebe um número de processo. Veja os requisitos para abertura e tramitação técnica de pedidos de registro.

Toque dos Sinos de São João Del Rei/ MG Proponente: Secretaria de Estado da Cultura de Minas Gerais

Data da abertura: 12/11/01

Tramitação - o processo foi encaminhado em 12/11/01 à 13ª Superintendência Regional do Iphan, em Minas Gerais, onde ainda se encontra para instrução.

A instrução técnica do processo foi assumida pelo Iphan, através da $13^{a}$ Superintendência Regional e do Departamento do Patrimônio Imaterial, que deram início ao Inventário de Referências Culturais para sistematização dos conhecimentos sobre esta forma de expressão. No momento o projeto está paralisado, aguardando recursos para sua continuidade.

Queijo do Serro/ MG

Proponente: Secretaria do Estado da Cultura de Minas Gerais e Associação dos Amigos do Serro

Data da abertura: 12/11/01

Tramitação - o processo foi encaminhado à $13^{a}$ Superintendência Regional do Iphan, 12/11/01, para complementação da instrução técnica, a ser realizada pelo proponente, SEC/lepha-MG. 
Obra do Poeta Patativa do Assaré/CE

Proponente: $4^{\mathrm{a}}$ Superintendência Regional do Iphan e Instituto de Arquitetos do Brasil/ CE

Data da abertura:17/10/02

Tramitação - O dossiê de estudos foi encaminhado à $4^{\mathrm{a}}$ Superintendência Regional em 09/12/02 para complementação da instrução técnica do processo.

Banda Cabaçal dos Irmãos Aniceto de Crato/ CE

Proponente: $4^{\text {a }}$ Superintendência Regional do IPHAN e Instituto de Arquitetos do Brasil/ CE

Data da abertura: 17/10/02

Tramitação - O dossiê de estudos foi encaminhado à $4^{a}$ Superintendência Regional em 09/12/02 para complementação da instrução técnica do processo.

Festa do Pau da Bandeira de Santo Antônio, Barbalha/ CE

Proponente: 4ª Superintendência Regional do IPHAN e Instituto de Arquitetos do Brasil/ CE

Data da abertura: $17 / 10 / 02$

Tramitação - O dossiê de estudos foi encaminhado à $4^{\mathrm{a}}$ Superintendência Regional em 09/12/02 para complementação da instrução técnica do processo.

Festa do Glorioso São Benedito de Angra dos Reis - RJ

Proponente: Irmandade do Glorioso São Benedito da Cidade de Angra dos Reis/ RJ

Data da abertura: 20/11/02 
Tramitação - O dossiê de estudos foi encaminhado à $6^{\text {a }}$ Superintendência Regional do Iphan, no Rio de Janeiro, em 28/11/02 para complementação da instrução técnica do processo.

\section{Requisitos para Registro de Bens Culturais Imateriais}

Os requisitos que devem ser cumpridos no processo de Registro de um bem cultural de natureza imaterial, conforme previsto no Decreto $n^{\circ} 3551 / 2000$, são os seguintes:

1 - Apresentação de requerimento, em documento original, datado e assinado, acompanhado obrigatoriamente das seguintes informações e documentos:

I - identificação do proponente;

II - denominação e descrição do bem proposto para registro, com indicação do que consiste, da participação e atuação dos grupos sociais envolvidos (os produtores do bem), do local onde ocorre ou se situa, do período e da forma em que ocorre;

III - documentação iconográfica disponível, adequada à natureza do bem, tais como fotografias, desenhos, vídeos, filmes, gravações sonoras, partituras, etc; IV - declaração formal de representante da comunidade produtora do bem, ou de seus membros, demonstrando o interesse e a anuência com a instauração do

processo de registro.

2 - A instrução técnica do processo (que significa produção e/ou sistematização de conhecimento sobre o bem) consiste em: 
I - elaboração de descrição pormenorizada do bem que contemple todos os seus

elementos culturalmente relevantes - identificação dos produtores, formas de produção, contexto cultural específico, significados atribuídos no processo de produção, circulação e consumo - sua origem e evolução histórica, dados etnográficos e sociológicos (essa descrição pode ser elaborada por meio da aplicação da metodologia do Inventário Nacional de Referências Culturais, sob supervisão do Departamento do Patrimônio Imaterial/Iphan);

II - referências documentais e bibliográficas;

III - reunião e apresentação de todo o material bibliográfico e audiovisual produzido sobre o bem e/ou que Ihe seja pertinente;

IV - complementação ou produção de documentação audiovisual que dê conta do bem cultural

*Está previsto um prazo de até 18 (dezoito) meses para execução desta etapa.

\section{Bens registrados}

Arte Kusiwa | Samba de Roda no Recôncavo Baiano

Ofício das Paneleiras de Goiabeiras | Círio de Nossa Senhora de Nazaré Acarajé | Viola-de-cocho

Ofício das Paneleiras de Goiabeiras Livro dos Saberes 
O Ofício das Paneleiras de Goiabeiras foi o primeiro bem cultural inscrito no Livro de Registro dos Saberes, em 20 de dezembro de 2002. O Registro foi feito a pedido da Associação das Paneleiras de Goiabeiras e pela Secretaria Municipal de Cultura de Vitória, Espírito Santo.

A fabricação artesanal de panelas de barro em Goiabeiras Velha, Vitória do Espírito Santo, é uma atividade eminentemente feminina e constitui um saber repassado de mãe para filha por gerações sucessivas. É também o meio de vida de mais de 120 famílias, muitas das quais aparentadas entre si.

Utiliza-se técnica cerâmica de origem indígena, possivelmente das tradições Tupi-Guarani e Una, caracterizada pela modelagem manual, queima a céu aberto e aplicação de tintura de tanino. O processo de produção das panelas de barro emprega matérias-primas provenientes do meio natural: a argila é retirada de um barreiro no Vale do Mulembá, localizado na Ilha de Vitória e a casca de mangue vermelho, com que é feita a tintura de tanino, é coletada diretamente do manguezal, à beira do qual Goiabeiras se desenvolveu.

Essas panelas são o suporte físico indispensável para fazer e servir a moqueca capixaba - referência obrigatória da culinária e ícone da identidade cultural regional. As paneleiras costumam dizer que "se cozinha qualquer coisa na panela de barro, mas peixe e marisco têm que ser na panela de barro".

As ações destinadas a manter a continuidade deste ofício levam em conta a organização comunitária, a prospecção de mercados e a preservação do ambiente que guarda suas matérias-primas essenciais: a jazida de argila ou barreiro e o mangue de onde é extraída a tintura de tanino.

A síntese da descrição do Ofício das Paneleiras está na Certidão do Registro desta forma de expressão. 
Festa em defesa do barreiro do Vale Mulembá, com a venda de panelas de Goiabeiras e atividade orientada para crianças

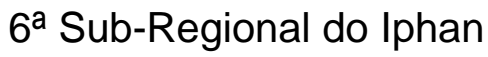

Arte Kusiwa - Pintura Corporal e Arte Gráfica Wajãpi

Livro de Registro das Formas de Expressão

A Arte Kusiwa é uma técnica de pintura e arte gráfica própria da população indígena Wajãpi, do Amapá.

Os grafismos podem ter como suporte o corpo humano, mas também cestos, cuias, tecelagem, bordunas e objetos de madeira. Os padrões Kusiwa representam animais, partes do corpo ou objetos e estão carregados de significados e simbolismo. Constituem um sistema de comunicação e uma linguagem gráfica que remete à cosmologia e visão de mundo dos Wajãpi. Para a elaboração das tintas são utilizadas sementes de urucum, gordura de macaco, suco de jenipapo e resinas perfumadas.

Através dos séculos, os Wajãpi desenvolveram uma linguagem única, formada por componentes gráficos e orais, que reflete sua visão de mundo e constitui um conhecimento específico sobre a vida em comunidade. A Arte Kusiwa faz também referência à criação da humanidade e a diversos mitos Wajãpi. Os múltiplos significados nos níveis sociológico, cultural, estético, religioso e metafísico indicam que a importância da Arte Kusiwa extrapola o seu lugar de arte gráfica e, efetivamente, engloba o vasto e complexo sistema que envolve sua maneira específica de compreender, perceber e interagir com o universo. 
O apoio à continuidade dessa forma de expressão está sendo feito por meio de diversas ações: elaboração de campanhas de sensibilização e informação; difusão, seletiva e controlada por seus detentores, da Arte Kusiwa; diagnóstico permanente do processo de revitalização da cultura oral; implantação de um Centro de Referências da Cultura Wajãpi; e, finalmente, a formação de professores indígenas, responsáveis pela alfabetização das crianças em sua língua materna e pela elaboração de materiais didáticos de interesse da comunidade.

A Arte Kusiwa foi proposta para Registro como Patrimônio Cultural Brasileiro pelo Conselho das Aldeias Wajãpi - Apina; pelo Núcleo de História Indígena e do Indigenismo da Universidade de São Paulo; pelo Núcleo de Educação Indígena do Governo do Estado do Amapá; e pelo Museu do Índio da Funai. O Conselho Consultivo do Iphan aprovou a inscrição da Arte Kusiwa no Livro de Registro das Formas de Expressão, em 20 de dezembro de 2002. No ano seguinte, recebeu da Unesco o título de Obra-prima do Patrimônio Oral e Imaterial da Humanidade.

A síntese da descrição da Arte Kusiwa - pintura corporal e arte gráfica Wajãpi está na Certidão de Registro desta forma de expressão.

\section{Círio de Nazaré}

Livro das Celebrações

O Círio de Nazaré uma celebração religiosa de Belém do Pará, cujo ápice ocorre na segunda semana do mês de outubro. Para os paraenses, é o grande momento anual de demonstração de devoção e solidariedade, de reiteração de laços familiares, assim como de manifestação social e política. 
O Círio de Nazaré apresenta uma estrutura complexa que agrega diferentes celebrações e festividades, antes e depois do evento principal - a procissão do Círio. Essas práticas têm desdobramentos regionais e congregam, anualmente, no segundo domingo de outubro, em torno de um milhão e meio de pessoas na cidade de Belém. Grande parte dessa massa humana vem pagar promessas ou agradecer pedidos realizados - muitos dos quais representados por exvotos ou objetos feitos de meriti.

O Círio de Nazaré reúne devotos, romeiros ou promesseiros do Pará, da Amazônia e das demais regiões do país. Além dessa mobilização humana decorrente da devoção popular, os festejos religiosos e profanos em torno do Círio atraem também turistas e curiosos de todas as partes do Brasil e até de países estrangeiros.

A festa, que foi instituída em 1793, é marcada pelo sentido da rememoração. O Círio de Nazaré reconta, por meio de seu cerimonial religioso, a lenda que envolve o achado, em 1700, da imagem de Nossa Senhora de Nazaré por um caboclo denominado Plácido. Sua duração temporal está associada à permanência da participação popular e à disseminação regional dos devotos, o que torna Belém, todos os anos, um lugar de peregrinação. Destaque-se, contudo, que a celebração, desde a origem, está envolta por práticas profanas, entre elas a montagem de um arraial dedicado historicamente ao comércio de alimentos e produtos regionais.

O Círio de Nazaré foi indicado pelo Conselho Consultivo do Patrimônio Cultural para a aplicação experimental dos procedimentos de Registro à categoria Celebrações. O pedido formal de Registro foi apresentado ao Iphan pela 
Arquidiocese de Belém, pela Diretoria das Festividades de Nazaré e pelas Obras Sociais da Paróquia de Nazaré.

\section{Samba de Roda no Recôncavo Baiano}

Livro de Registro das Formas de Expressão

O Samba de Roda baiano é uma expressão musical, coreográfica, poética e festiva das mais importantes e significativas da cultura brasileira. Presente em todo o estado da Bahia, ele é especialmente forte e mais conhecido na região do Recôncavo, a faixa de terra que se estende em torno da baía de Todos os Santos. Seus primeiros registros, já com esse nome e com muitas das características que ainda hoje o identificam, datam dos anos 1860.

O Samba de Roda pode ser realizado em associação com o calendário festivo - caso das festas da Boa Morte, em Cachoeira, em agosto, de São Cosme e Damião, em setembro, e de sambas ao final de rituais para caboclos em terreiros de candomblé. Mas ele pode também ser realizado em qualquer momento, como uma diversão coletiva, pelo prazer de sambar.

Historiadores da música popular consideram o Samba de Roda baiano como uma das fontes do samba carioca que, como se sabe, veio a tornar-se, no decorrer do século XX, um símbolo indiscutível de brasilidade. A narrativa de origem do samba carioca remete à migração de negros baianos para o Rio de Janeiro ao final do século XIX, que teriam buscado reproduzir, nos bairros situados entre o canal do Mangue e o cais do porto, seu ambiente cultural de origem, onde a religião, a culinária, as festas e o samba eram partes destacadas. Parece indiscutível que as famosas tias baianas - como tia Amélia, tia Perciliana e sobretudo tia Ciata - e seus filhos - como Donga e 
João da Baiana - tiveram papel de relevo na fase pioneira do samba no Rio de Janeiro, sobretudo até meados dos anos 1920.

Depois disso, o Samba de Roda baiano continuou sendo uma das referências do samba nacional, presente nas obras de baianos nacionais como Dorival Caymmi, João Gilberto e Caetano Veloso, assim como na ala das baianas das escolas de samba e nas letras de inúmeros compositores de todo o país.

A proposta de Registro foi encaminhada ao Iphan pela Associação Cultural do Samba de Roda Dalva Damiana, pelo Grupo Cultural Filhos de Nagô e pela Associação de Pesquisa em Cultura Popular e Música Tradicional do Recôncavo.

\section{Acarajé}

O Ofício das Baianas de Acarajé, em Salvador, Bahia, consiste em uma prática tradicional de produção e venda em tabuleiro das chamadas comidas de baiana ou comidas de azeite, em que se destaca o acarajé, um bolinho de feijão fradinho, frito no azeite de dendê.

A feitura do acarajé foi trazida pelas escravas negras no período colonial e tem sido reproduzida no Brasil há vários séculos. Na maior parte do tempo foi transmitida oralmente por sucessivas gerações. O acarajé era comercializado no período colonial pelas chamadas escravas de ganho ou negras libertas, proporcionando a sobrevivência dessas últimas após a abolição da escravatura. No decorrer dos séculos essa comida, que teve uma origem sagrada, associada ao culto de divindades do candomblé, passou a marcar toda a sociedade baiana como um valor alimentar integrado à culinária regional. 
O acarajé, com seus recheios habituais, além do abará, acaçá, fato, bolinho de estudante, cocadas, bolos, mingaus, são vendidos em tabuleiros instalados pelas baianas em lugares que lembram os antigos cantos, pontos dos escravos que comercializavam produtos no período colonial. Atualmente, os grupos sociais que vendem as comidas de baiana são compostos por filhas de santo, no contexto religioso do candomblé e por baianos e baianas de acarajé, no contexto da comercialização como meio de vida.

Os elementos essenciais do Ofício das Baianas de Acarajé compreendem os rituais envolvidos na produção do acarajé, na arrumação do tabuleiro e na preparação do lugar onde as baianas se instalam; os modos de fazer as comidas de baiana; o uso do tabuleiro para venda das comidas; a comercialização informal em logradouros, feiras e festas de largo; o uso da indumentária própria das baianas, como marca distintiva de sua condição social e religiosa, presente especialmente nos panos da costa, nos turbantes, nos fios de contas e outras insígnias.

O pedido de Registro do Ofício das Baianas de Acarajé em Salvador, Bahia, foi solicitado pela Associação de Baianas de Acarajé e Mingau do Estado da Bahia, juntamente com o Centro de Estudos Afro-Orientais de Universidade Federal da Bahia e o Terreiro llê Axé Opô Afonjá. Foi inscrito no Livro dos Saberes, como patrimônio cultural brasileiro, em 10 de dezembro de 2004, a partir da decisão proferida na $45^{\mathrm{a}}$ Reunião do Conselho Consultivo do Patrimônio Cultural, realizada em $1^{\circ}$ de dezembro de 2004.

Viola-de-cocho 
A Viola-de-Cocho é um instrumento musical singular quanto à forma e sonoridade, produzido exclusivamente de forma artesanal, com a utilização de matérias-primas existentes na Região Centro-Oeste do Brasil. Seu nome devese à técnica de escavação da caixa de ressonância da viola em uma tora de madeira inteiriça, mesma técnica utilizada na fabricação de cochos (recipientes em que é depositado o alimento para o gado).

A solicitação de Registro da Viola-de-Cocho foi encaminhada ao Centro Nacional de Cultura Popular - CNPC por interessados e comunidades residentes nos Estados de Mato Grosso e Mato Grosso do Sul e, em especial, por artesãos e instrumentistas da Viola-de-Cocho. A solicitação de Registro refere-se, especificamente, à proteção e valorização da Viola-de-Cocho e das expressões musicais, poéticas e coreográficas do cururu e do siriri, todas elas manifestações originais e exclusivas desta região do país. Suas origens são pouco claras, e há quem postule que tenha vindo de São Paulo, acompanhando a expansão bandeirante para a Região Centro-Oeste brasileira. O instrumento integra o complexo musical, coreográfico e poético do cururu e do siriri - juntamente com o ganzá (reco-reco de taquara) e o tamborim ou mocho (banco cujo assento de couro é percutido com baquetas de madeira) cultivado por segmentos das camadas populares como diversão ou devoção a santos católicos.

Sua produção é realizada por mestres cururueiros, seja para uso próprio, seja para atender à demanda do mercado local, também constituída por cururueiros e mestres da dança do siriri. Os materiais utilizados tradicionalmente para a sua confecção são retirados do ecossistema da região. No entanto, restrições à 
caça e à utilização dos recursos naturais local têm exigido a substituição de algumas das matérias-primas originais por produtos industrializados.

A relação entre a Viola-de-Cocho e as manifestações musicais e coreográficas acima referidas, vinculadas ainda a vários rituais e seus respectivos elementos materiais e simbólicos, são de caráter essencial e unívoco, não se podendo dissociar uma das outras, e nem entender cada uma delas sem a compreensão de suas articulações com as demais. Neste sentido, entendemos que a Violade-Cocho, como bem cultural, corresponde a um modo de fazer único e especial, caracterizando um ofício com suas formas de produção e de execução artístico-musical, geralmente associadas a formas de expressão específicas, dentre as quais se destacam o cururu e o siriri.

Em decisão proferida na $45^{\mathrm{a}}$ Reunião do Conselho Consultivo do Patrimônio Cultural realizada em $1^{\circ}$ de dezembro de 2004, o Modo de Fazer Viola-deCocho foi inscrito no Livro de Registro dos Saberes, com a devida menção ao complexo musical, coreográfico e poético do siriri e do cururu, em 10 de dezembro de 2004. 
Anexo E

Quadro de Representação das Entidades do Conselho Nacional de Turismo nas Câmaras Temáticas, cedido pela Coordenação do CNT 
MINISTÉRIO DO TURISMO

Secretaria de Políticas de Turismo

Departamento de Planejamento e Avaliação

Quadro de Representação das Entidades do Conselho Nacional de Turismo nas Câmaras Temáticas

\begin{tabular}{|c|c|c|c|c|c|c|c|c|c|c|}
\hline \multirow[b]{2}{*}{ ENTIDADE } & \multirow[b]{2}{*}{ PARTICIPANTE } & \multicolumn{9}{|c|}{ CÂMARAS } \\
\hline & & Legislação & Regionalização & $\begin{array}{l}\text { Qualificação } \\
\text { Profissional }\end{array}$ & $\begin{array}{l}\text { Financiamento } \\
\text { e Investimento }\end{array}$ & Segmentação & $\begin{array}{c}\text { Infra- } \\
\text { Estrutura }\end{array}$ & $\begin{array}{c}\text { Promoção e } \\
\text { Apoio a } \\
\text { Comercializa }\end{array}$ & $\begin{array}{c}\begin{array}{c}\text { Qualificação } \\
\text { da }\end{array} \\
\text { Superestrut. }\end{array}$ & $\begin{array}{c}\text { Particip. } \\
\text { da } \\
\text { Entidade } \\
(\%)\end{array}$ \\
\hline \multirow{5}{*}{ ABAV } & Daniel Corato & & & & & & & & & \multirow{5}{*}{$75 \%$} \\
\hline & $\begin{array}{l}\text { Eugênio } \\
\text { Antinoro }\end{array}$ & & & & & & & & & \\
\hline & Leonel Rossi & & & & & & & & & \\
\hline & $\begin{array}{l}\text { Paulo } \\
\text { Wiedmann }\end{array}$ & & & & & & & & & \\
\hline & Tarso Gadzanis & & & & & & & & & \\
\hline \multirow[t]{2}{*}{ ABBTUR } & $\begin{array}{l}\text { Maria } \\
\text { Providência }\end{array}$ & & & & & & & & & \multirow{2}{*}{$25 \%$} \\
\hline & Noslin de Paula & & & & & & & & & \\
\hline $\mathrm{ABCMI}$ & Nadir Parigot & & & & & & & & & $12,5 \%$ \\
\hline \multirow{5}{*}{ ABEOC } & $\begin{array}{l}\text { Alexandre } \\
\text { Werfel }\end{array}$ & & & & & & & & & \multirow{5}{*}{$87,5 \%$} \\
\hline & $\begin{array}{l}\text { Constança } \\
\text { Carvalho }\end{array}$ & & & & & & & & & \\
\hline & Elenita do Vale & & & & & & & & & \\
\hline & $\begin{array}{l}\text { Nelson de } \\
\text { Souza Cunha }\end{array}$ & & & & & & & & & \\
\hline & $\begin{array}{l}\text { Sérgio Luiz } \\
\text { Bicca }\end{array}$ & & & & & & & & & \\
\hline \multirow{8}{*}{$\mathrm{ABIH}$} & $\begin{array}{l}\text { Abdon Barreto } \\
\text { Filho }\end{array}$ & & & & & & & & & \multirow{8}{*}{$87,5 \%$} \\
\hline & $\begin{array}{l}\text { Alexandre } \\
\text { Sampaio }\end{array}$ & & & & & & & & & \\
\hline & $\begin{array}{l}\text { Evanilsom } \\
\text { Montenegro }\end{array}$ & & & & & & & & & \\
\hline & Helder Carneiro & & & & & & & & & \\
\hline & $\begin{array}{l}\text { Moacir } \\
\text { Florentino } \\
\end{array}$ & & & & & & & & & \\
\hline & Pedro Fortes & & & & & & & & & \\
\hline & Rita Bicalho & & & & & & & & & \\
\hline & Tomaz Ikeda & & & & & & & & & \\
\hline \multirow{4}{*}{ ABLA } & Alberto Faria & & & & & & & & & \multirow{4}{*}{$62,5 \%$} \\
\hline & Carlos Faustino & & & & & & & & & \\
\hline & Nildo Pedrosa & & & & & & & & & \\
\hline & Weber Santos & & & & & & & & & \\
\hline \multirow{4}{*}{ ABRACEF } & Gisa Neves & & & & & & & & & \multirow{4}{*}{$50 \%$} \\
\hline & $\begin{array}{l}\text { Margareth } \\
\text { Pizzato }\end{array}$ & & & & & & & & & \\
\hline & Sérgio Camilo & & & & & & & & & \\
\hline & Sérgio Campos & & & & & & & & & \\
\hline \multirow{3}{*}{ ABRASEL } & Carlos Vargas & & & & & & & & & \multirow{3}{*}{$37,5 \%$} \\
\hline & $\begin{array}{l}\text { Edson de } \\
\text { Souza }\end{array}$ & & & & & & & & & \\
\hline & $\begin{array}{l}\text { Maria de F. } \\
\text { Hamú }\end{array}$ & & & & & & & & & \\
\hline \multirow{3}{*}{ ABRATURR } & Andréia Roque & & & & & & & & & \multirow{3}{*}{$37,5 \%$} \\
\hline & Cássio Oliveira & & & & & & & & & \\
\hline & Renato Bravo & & & & & & & & & \\
\hline \multirow{4}{*}{ ABRESI } & José Gusmão & & & & & & & & & \multirow{4}{*}{$62,5 \%$} \\
\hline & Luiz F. Quental & & & & & & & & & \\
\hline & Flávia Starling & & & & & & & & & \\
\hline & $\begin{array}{l}\text { Nelson de } \\
\text { Abreu }\end{array}$ & & & & & & & & & \\
\hline ABS & $\begin{array}{l}\text { Alexandre } \\
\text { Zubanan }\end{array}$ & & & & & & & & & $25 \%$ \\
\hline & Alain Baldacci & & & & & & & & & \\
\hline ADIBRA & $\begin{array}{l}\text { Armando } \\
\text { Pereira Filho }\end{array}$ & & & & & & & & & $50 \%$ \\
\hline ANTTUR & & & & & & & & & & $50 \%$ \\
\hline
\end{tabular}




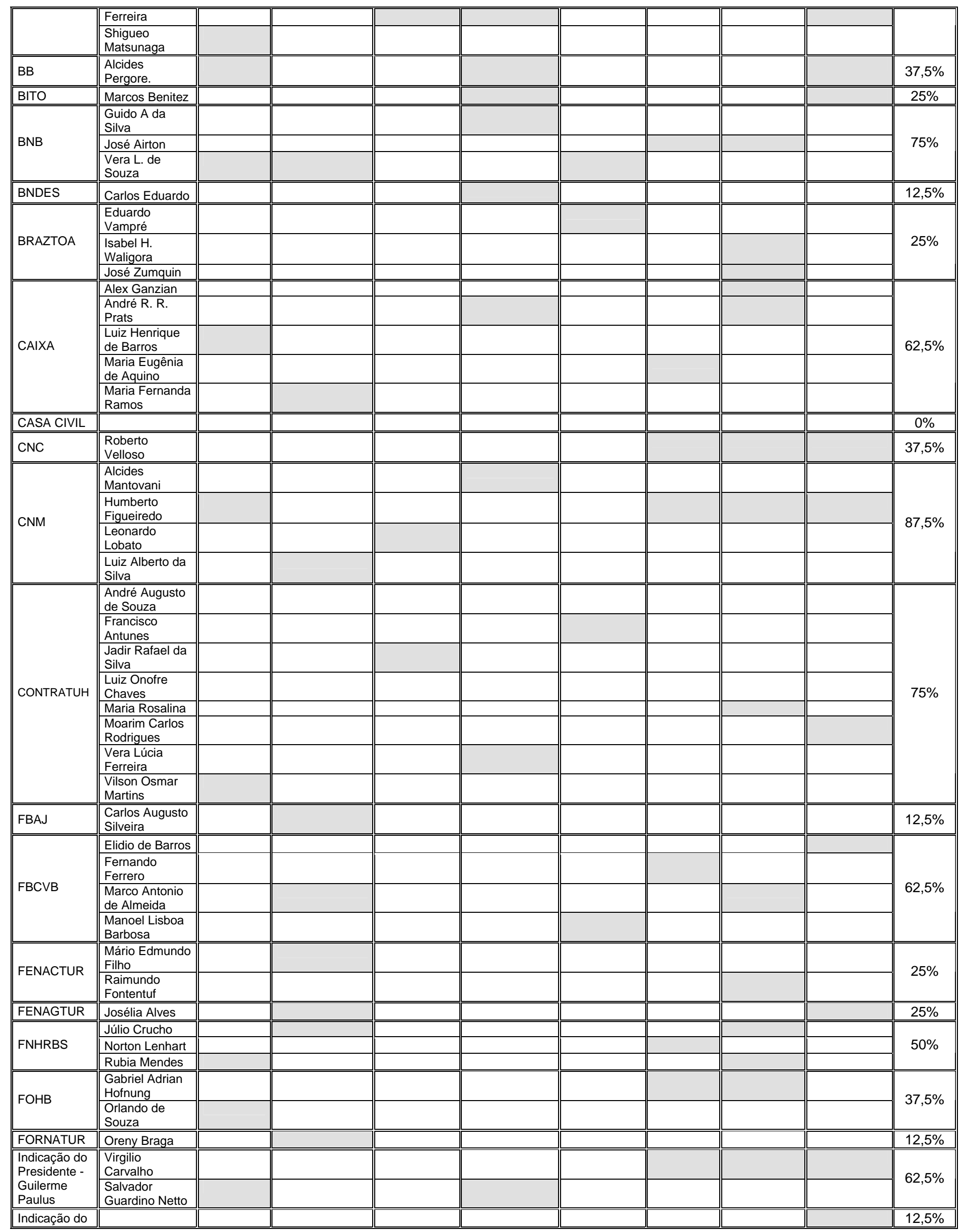




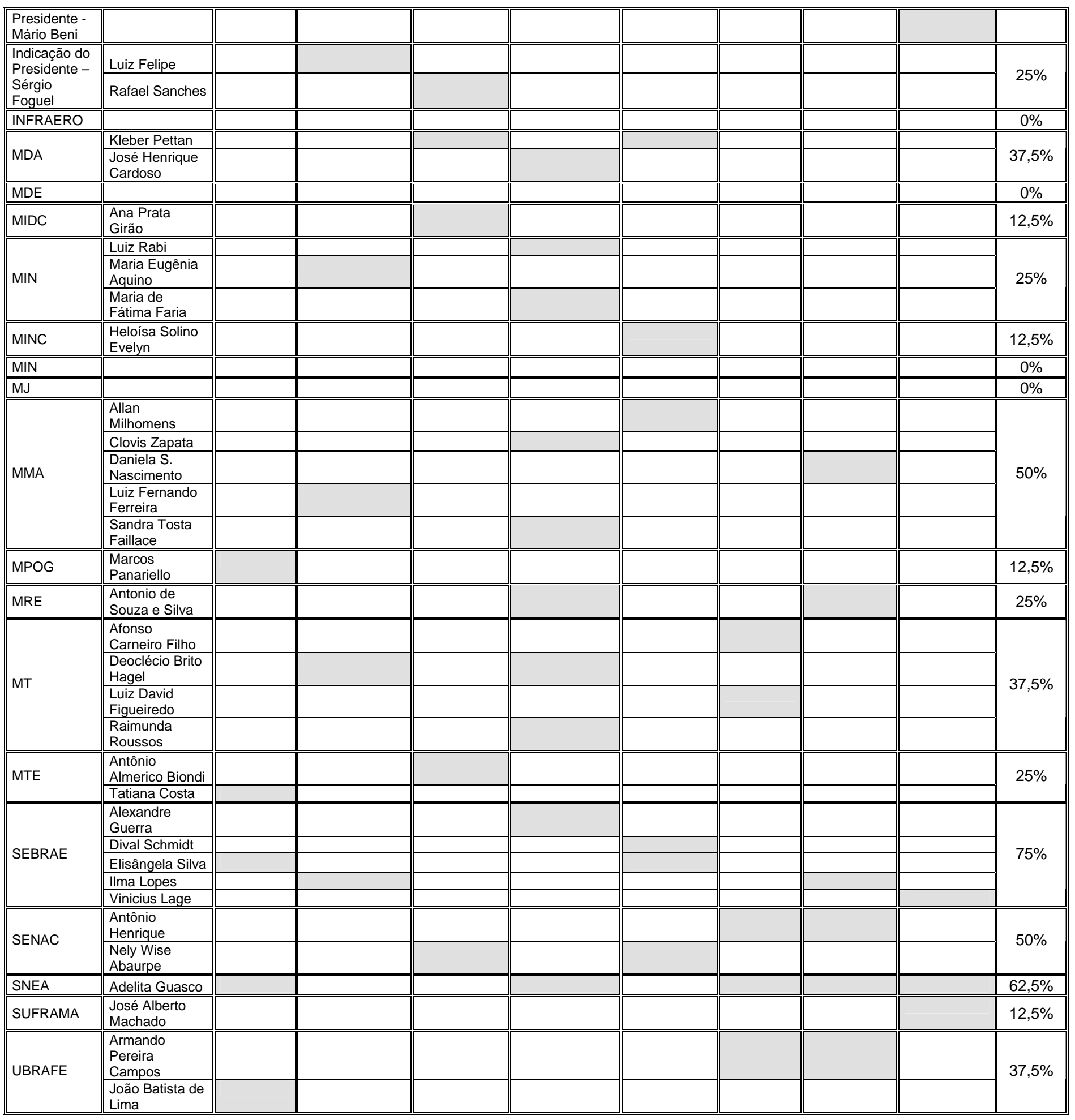


Anexo F

Levantamento de Presenças das Entidades nas Reuniões do Conselho Nacional de Turismo, cedido pela Coordenação do CNT (DPA/MartaFeitosa

Atualizado em 27/06/05) 


\section{诌}

MINISTÉRIO DO TURISMO

Conselho Nacional de Turismo

Levantamento de Presenças da Entidades nas Reuniões do Conselho

\begin{tabular}{|c|c|c|c|c|c|c|c|c|c|c|}
\hline ENTIDADE & $\begin{array}{c}1^{\text {a }} \text { Reunião } \\
\text { 30/04/03 } \\
\text { Brasília }\end{array}$ & $\begin{array}{c}2^{a} \text { Reunião } \\
\text { 11/08/03 } \\
\text { Brasília }\end{array}$ & $\begin{array}{c}3^{a} \text { Reunião } \\
\text { 27/11/03 } \\
\text { Brasília }\end{array}$ & $\begin{array}{c}4^{a} \text { Reunião } \\
11 / 03 / 04 \\
\text { Brasília }\end{array}$ & $\begin{array}{c}5^{\text {a }} \text { Reunião } \\
\text { 03/06/04 } \\
\text { Brasília }\end{array}$ & $\begin{array}{c}6^{\circ} \text { Reunião } \\
\text { 02/09/04 } \\
\text { Brasília }\end{array}$ & $\begin{array}{c}7^{\circ} \text { Reunião } \\
\text { 02/12/04 } \\
\text { Salvador }\end{array}$ & $\begin{array}{c}8^{a} \text { Reunião } \\
\text { 03/03/05 } \\
\text { Brasília }\end{array}$ & $\begin{array}{c}9^{a} \text { Reunião } \\
\text { 08/06/05 } \\
\text { Belo } \\
\text { Horizonte }\end{array}$ & $\begin{array}{c}\text { Presença } \\
\text { (\%) }\end{array}$ \\
\hline ABAV- Associação Brasileira de Agências de Viagens & & & & & & & & & & $89 \%$ \\
\hline ABBTUR - Associação Brasileira dos Bacharéis em Turismo & & & & & & & & & & $100 \%$ \\
\hline ABCMI NACIONAL - Associação Brasileira dos Clubes da Melhor Idade & $\begin{array}{c}\text { NÃO } \\
\text { PARTICIPAVA }\end{array}$ & $\begin{array}{c}\text { NÃO } \\
\text { PARTICIPAVA }\end{array}$ & $\begin{array}{c}\text { NÃO } \\
\text { PARTICIPAVA }\end{array}$ & & & & & & & $83 \%$ \\
\hline ABEOC - Associação Brasileira de Empresas de Eventos & & & & & & & & & & $78 \%$ \\
\hline ABETA - Associação Brasileira das Empresas de Turismo de Aventura & $\begin{array}{l}\text { NÃO } \\
\text { PARTICIPAVA }\end{array}$ & $\begin{array}{l}\text { NãO } \\
\text { PARTILIPAVA }\end{array}$ & $\begin{array}{l}\text { NÃO } \\
\text { PARTICIPAVA }\end{array}$ & $\begin{array}{l}\text { NãO } \\
\text { PARTICIPAVA }\end{array}$ & $\begin{array}{l}\text { NãO } \\
\text { PARTICIPAVA }\end{array}$ & $\begin{array}{l}\text { NãO } \\
\text { PARTICIPAVA }\end{array}$ & $\begin{array}{l}\text { NÃO } \\
\text { PARTICIPAVA }\end{array}$ & & & $50 \%$ \\
\hline ABETAR - Associação Brasileira das Empresas Aéreo Regional & $\begin{array}{l}\text { NãO } \\
\text { PARTIIIPAVA }\end{array}$ & $\begin{array}{l}\text { NãO } \\
\text { PARTIIIPAVA }\end{array}$ & $\begin{array}{l}\text { NãO } \\
\text { PARTICIPAVA }\end{array}$ & $\begin{array}{l}\text { NãO } \\
\text { PARTIIIPAVA }\end{array}$ & $\begin{array}{l}\text { NÃO } \\
\text { PARTICIPAVA }\end{array}$ & $\begin{array}{l}\text { NãO } \\
\text { PARTIIIPAVA }\end{array}$ & $\begin{array}{l}\text { NãO } \\
\text { PARTIIIPAVA }\end{array}$ & & & $100 \%$ \\
\hline ABIH - Associação Brasileira da Indústria Hoteleira & & & & & & & & & & $100 \%$ \\
\hline ABLA - Associação Brasileira das Locadoras de Automóveis & & & & & & & & & & $67 \%$ \\
\hline ABONG - Associação Brasileira de Organizações Não Governamentais & \multicolumn{10}{|c|}{ Não indicou Representante } \\
\hline ABRACAMPING - Associação Brasileira de Campismo & $\begin{array}{l}\text { NãO } \\
\text { PARTIIIPAVA }\end{array}$ & $\begin{array}{l}\text { NãO } \\
\text { PARTIIIPAVA }\end{array}$ & $\begin{array}{l}\text { NÃO } \\
\text { PARTIIIPAVA }\end{array}$ & $\begin{array}{l}\text { NãO } \\
\text { PARTIIIPAVA }\end{array}$ & $\begin{array}{l}\text { NãO } \\
\text { PARTIIIPAVA }\end{array}$ & $\begin{array}{l}\text { NãO } \\
\text { PARTIIIPAVA }\end{array}$ & $\begin{array}{l}\text { NãO } \\
\text { PARTIIIPAVA }\end{array}$ & & & $50 \%$ \\
\hline ABRACCEF- Associação Brasileira de Centros de Convenções e Feiras & & & & & & & & & & $44 \%$ \\
\hline ABRAJET - Associação Brasileira dos Jornalistas de Turismo & $\begin{array}{l}\text { NÃO } \\
\text { PARTICIPAVA }\end{array}$ & $\begin{array}{l}\text { NÃO } \\
\text { PARTICIPAVA }\end{array}$ & $\begin{array}{l}\text { NÃO } \\
\text { PARTICIPAVA }\end{array}$ & $\begin{array}{l}\text { NãO } \\
\text { PARTICIPAVA }\end{array}$ & $\begin{array}{l}\text { NÃO } \\
\text { PARTICIPAVA }\end{array}$ & & & & & $100 \%$ \\
\hline $\begin{array}{l}\text { ABRASEL- Associação Brasileira de Restaurantes e Empresas de } \\
\text { Entretenimento }\end{array}$ & & & & & & & & & & $78 \%$ \\
\hline ABRATURR - Associação Brasileira de Turismo Rural & & & & & & & & & & $78 \%$ \\
\hline
\end{tabular}




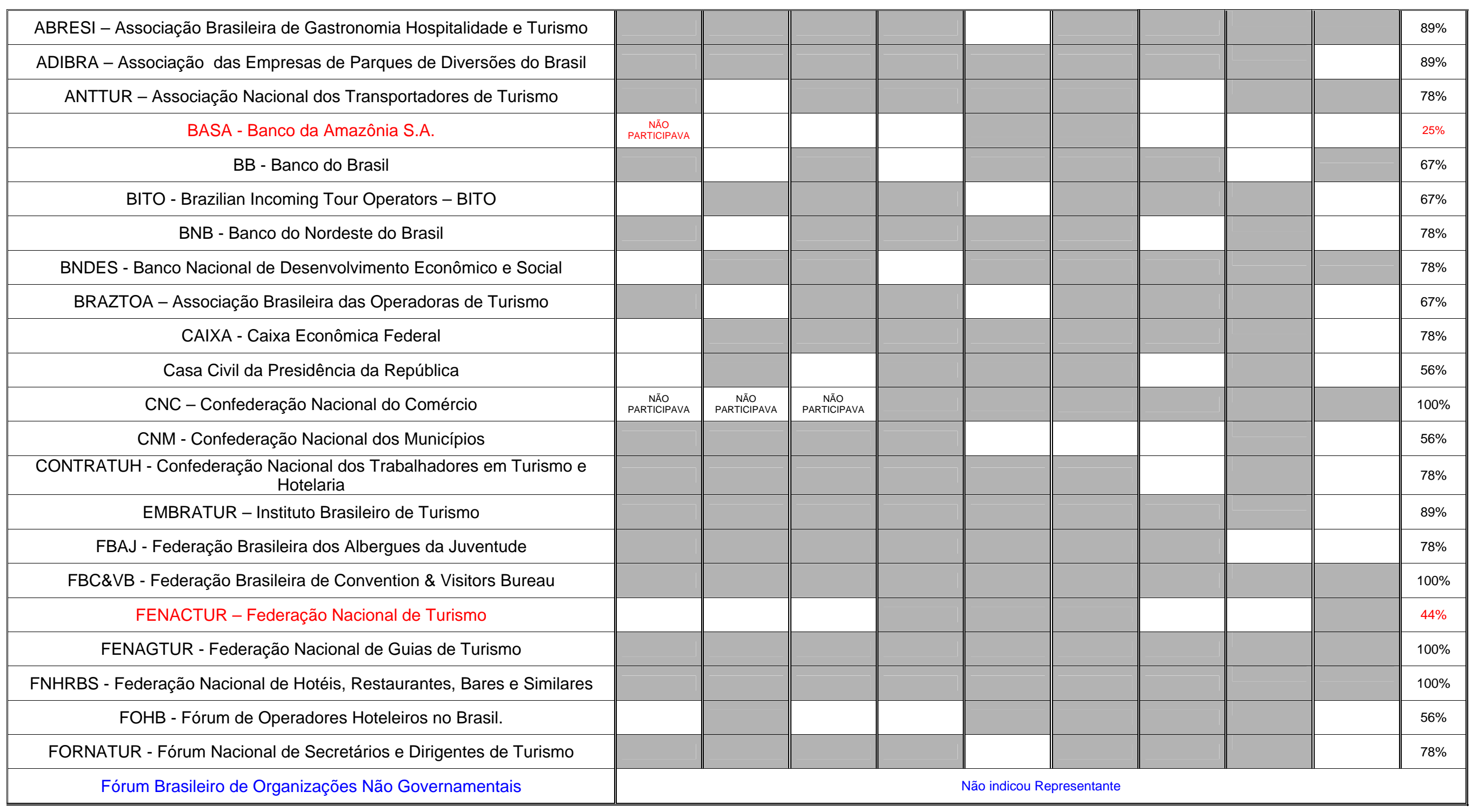




\begin{tabular}{|c|c|c|c|c|c|}
\hline Fórum Nacional dos Cursos Superiores de Turismo e Hotelaria & $\begin{array}{c}\text { NÃO } \\
\text { PARTICIPAVA }\end{array}$ & $\begin{array}{c}\text { NÃO } \\
\text { PARTICIPAVA }\end{array}$ & $\begin{array}{c}\text { NÃO } \\
\text { PARTICIPAVA }\end{array}$ & $\begin{array}{c}\text { NÃO } \\
\text { PARTICIPAVA }\end{array}$ & $\begin{array}{c}\text { NÃO } \\
\text { PARTICIPAVA }\end{array}$ \\
\hline Indicação do Presidente - Guilherme Paulus & & & & & \\
\hline Indicação do Presidente - Mário Beni & & & & & \\
\hline Indicação do Presidente - Sérgio Foguel & & & & & \\
\hline INFRAERO - Empresa Brasileira de Infra-Estrutura Aeroportuária & $\begin{array}{c}\text { NÃO } \\
\text { PARTICIPAVA }\end{array}$ & & & & \\
\hline MD - Ministério da Defesa & & & & & \\
\hline MDA - Ministério do Desenvolvimento Agrário & & & & & \\
\hline MDIC - Ministério do Desenvolvimento, Indústria e Comércio Exterior & & & & & \\
\hline MF - Ministério da Fazenda & $\begin{array}{c}\text { NÃO } \\
\text { PARTICIPAVA }\end{array}$ & & & & \\
\hline MI - Ministério da Integração Nacional & & & & & \\
\hline MINC - Ministério da Cultura & & & & & \\
\hline MJ - Ministério da Justiça & & & & & \\
\hline MPO - Ministério do Planejamento, Orçamento e Gestão. & & & & & \\
\hline MRE - Ministério das Relações Exteriores. & & & & & \\
\hline MT - Ministério do Transporte & & & & & \\
\hline MTE - Ministério do Trabalho e do Emprego & & & & & \\
\hline SEBRAE - Serviço de Apoio à Micro e Pequenas Empresas. & & & & & \\
\hline SECON - da Secretaria de Comunicação de Governo & & & & & Jão indicou re \\
\hline SENAC - Serviço Nacional do Comércio. & & & & & \\
\hline SNEA - Sindicato Nacional das Empr. Aeroviárias. & & & & & \\
\hline SUFRAMA - Superintendência da Zona Franca de Manaus & $\begin{array}{c}\text { NÃO } \\
\text { PARTICIPAVA }\end{array}$ & & & & \\
\hline UBRAFE - União Brasileira dos Promotores de Feira. & & & & & \\
\hline
\end{tabular}


Composição do Conselho Estadual de Turismo do Espírito Santo - CONTURES 


\section{Composição do Conselho Estadual de Turismo - CONTURES}

Secretaria de Estado de Desenvolvimento Econômico e Turismo - SEDETUR

Representante indicado pelo Ministério do Turismo

Região de Caparaó - Alegre, Divino Sanão Lorenço, Dores do Rio Preto, Guaçuí, Ibatiba, Ibitirama, Irupi, lúna, Muniz Freire, São José do Calçado

Região Litoral Norte - Aracruz, Conceição da Barra, Linhares, São Mateus, Rio Bananal, Jaguaré, Sooretama, Ibiraçu, Pedro Canário, João Neiva

Região Sul - Anchieta, Bom Jesus do Norte, Itapemirim, Marataízes, Piúma, Presidente Kennedy, Apiacá, Jerônimo Monteiro, Muqui, Mimoso do Sul, Cachoeiro de Itapemirim, Iconha, Atílio Vivácqua, Rio Novo do Sul

Região Metropolitana - Cariacica, Guarapari, Fundão, Serra, Viana, Vila Velha e Vitória

Região Centro Norte - Mantenópolis, Alto Rio Novo, Pancas, Águia Branca, São Gabriel da Palha, São

Domingos do Norte, Vila Valério, Marilândia, Colatina, Governador Lindenberg, Baixo Guandu

Região Norte - Mucurici, Montanha, Ponto Belo, Pinheiros, Boa Esperança, Vila Pavão, Ecoporanga, Água Doce do Norte, Barra de São Francisco, Nova Venécia

Região Serrana - Afonso Cláudio, Alfredo Chaves, Brejetuba, Conceição do Castelo, Domingos Martins, Itaguaçu, Itarana, Laranja da Terra, Marechal Floriano, Santa Leopoldina, Santa Maria de Jetibá, Santa Teresa, Venda Nova do Imigrante, Vargem Alta, São Roque do Canaã, Castelo.

Empresa Brasileira de Infra-estrutura Aeroportuária - INFRAERO

Companhia Docas do Espírito Santo - CODESA

Sindicato dos Transporte Público do Estado do Espírito Santo - SETPES

Associação Brasileira da Indústria de Hotéis - ABIH/ES

Sindicato de Hotéis e Hospedagem do Estado do Espírito Santo - SINDHOTÉIS

Sindicato das Empresas de Turismo do Estado do Espírito Santo - SINDETUR/ES

Associação Brasileira de Agências de Viagens do Estado do Espírito Santo - ABAVIES

Associação Brasileira de Jornalistas de Turismo do Estado do Espírito Santo - ABRAJET/ES

Serviço Nacional de Aprendizagem Comercial - SENAC

Serviço Nacional de Aprendizagem Rural - SENAR

Banco de Desenvolvimento do Estado do Espírito Santo - BANDES

Sindicato de Guias de Turismo do Estado do Espírito Santo - SINDEGTUR/ES

Confederação Nacional dos Estabelecimentos de Ensino - CONFENEN/ES

Associação Brasileira de Bacharéis e Estudantes de Turismo - ABBTUR/ES

Sindicato dos Bares e Restaurantes - SINDBARES

Associação Brasileira de Empresas Organizadoras de Eventos - ABOC/ES

Assembléia Legislativa do Estado do Espírito Santo - Comissão de Turismo

Espírito Santo Convention \& Visitors Bureau - ESCVB

Serviço Brasileiro de Apoio as Pequenas e Micro Empresas do Espírito Santo - SEBRAE/ES

Federação das Indústrias do Espírito Santo - FINDES

Federação dos Trabalhadores em Turismo e Hospitalidade do Estado do Espírito Santo - FETTHEES

Federação das Câmaras dos Dirigentes Lojistas do Estado do Espírito Santo - FCDL-ES

Conselho Regional de Administraação - CRA/ES 
Anexo $\mathrm{H}$

Fotos da Associação das Paneleiras de Goiabeiras 

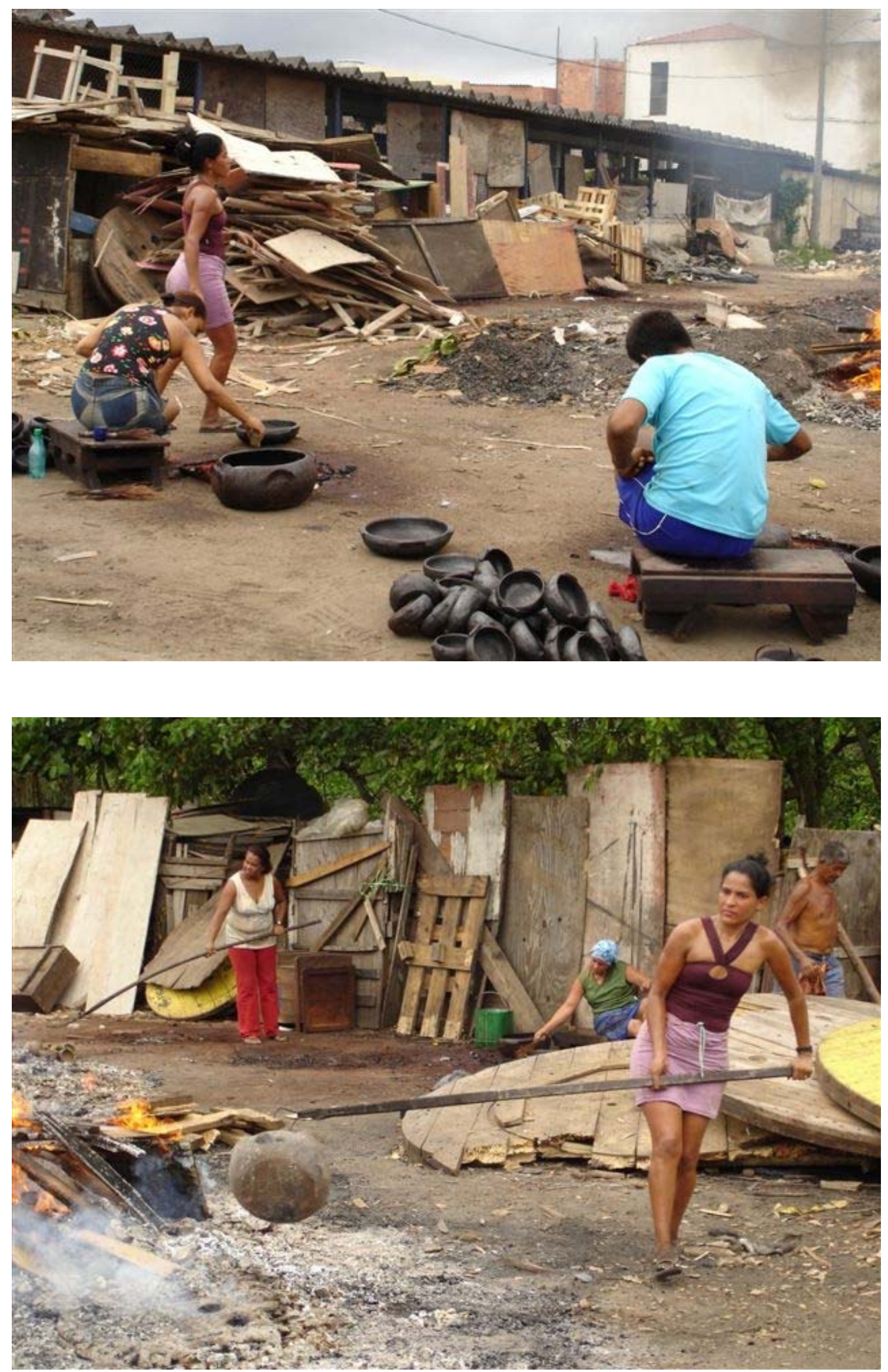
Anexo I

Planta Vitrine Brasil e os Produtos Associados ao Turismo apresentados pelos

9 Sítios Urbanos Patrimônios Mundiais no Brasil (Planta cedida por Ana

Zerbini, arquiteta do projeto). 

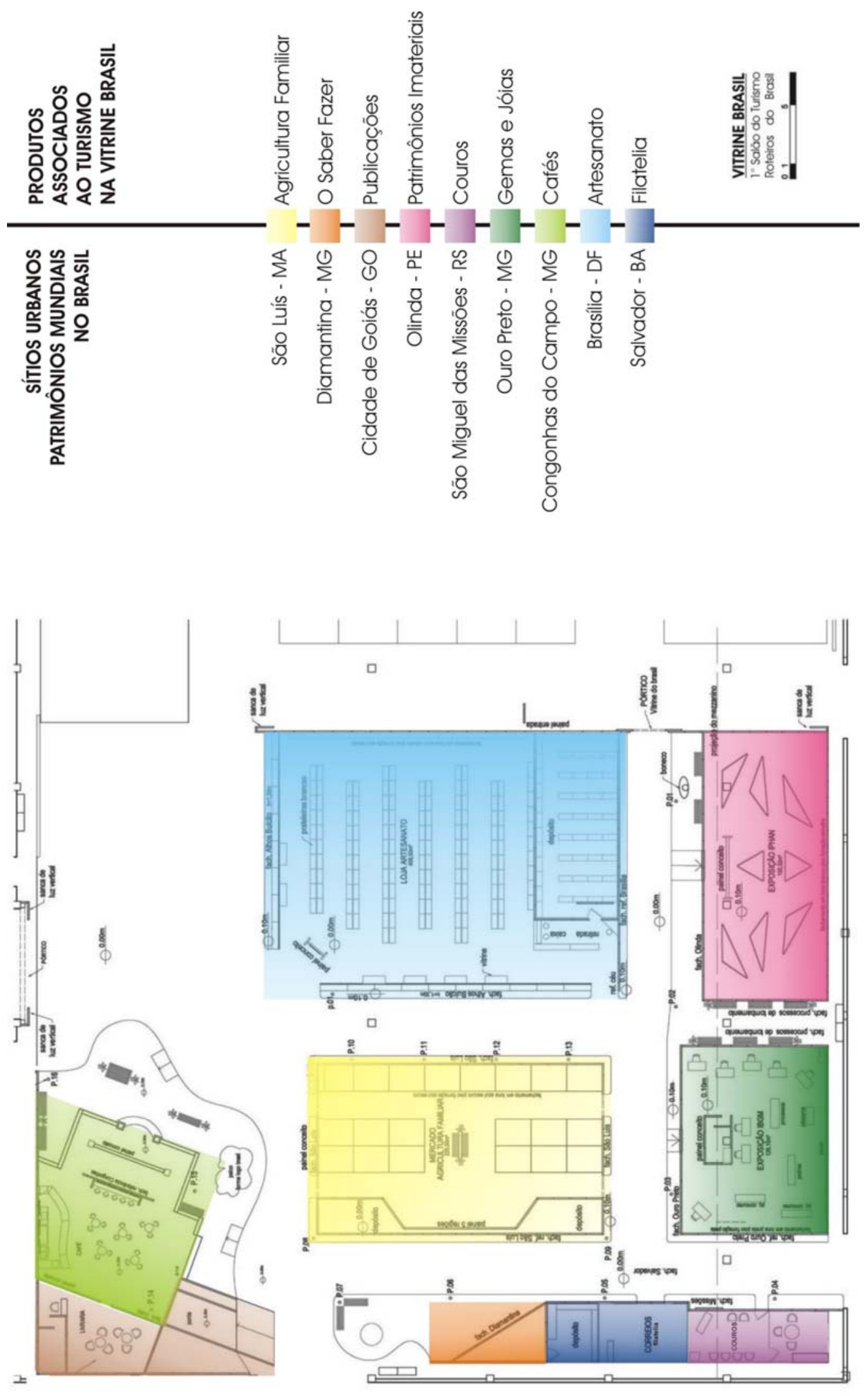